\title{
Status of Understanding of the Saturated-Zone Ground-Water Flow System at Yucca Mountain, Nevada, as of 1995
}

by Richard R. Luckey, Patrick Tucci, Claudia C. Faunt, Elisabeth M. Ervin, William C. Steinkampf, Frank A. D'Agnese, and Gary L. Patterson

\section{U.S. GEOLOGICAL SURVEY}

Water-Resources Investigations Report 96-4077

Prepared in cooperation with the

NEVADA OPERATIONS OFFICE,

U.S. DEPARTMENT OF ENERGY, under

Interagency Agreement DE-A108-92NV10874

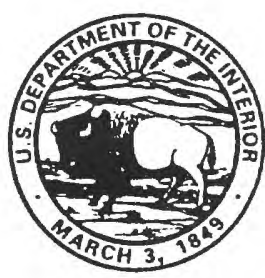




\title{
U.S. DEPARTMENT OF THE INTERIOR BRUCE BABBITT, Secretary
}

\author{
U.S. GEOLOGICAL SURVEY \\ Gordon P. Eaton, Director
}

The use of firm, trade, and brand names in this report is for identification purposes only and does not constitute endorsement by the U.S. Geological Survey.

For additional information write to:

Chief, Hydrologic Investigations Program Yucca Mountain Project Branch

U.S. Geological Survey

Box 25046, Mail Stop 421

Denver Federal Center

Denver, CO 80225-0046
Copies of this report can be purchased from:

U.S. Geological Survey

Branch of Information Services

Box 25286

Denver, CO 80225-0286 


\section{CONTENTS}

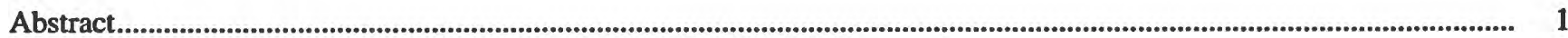

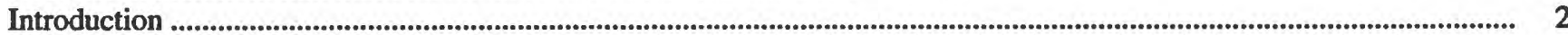

Historical and Regulatory Background ..................................................................................................... 2

Purpose and Scope..................................................................................................................................... 3

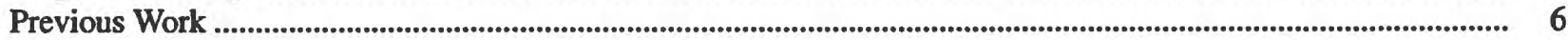

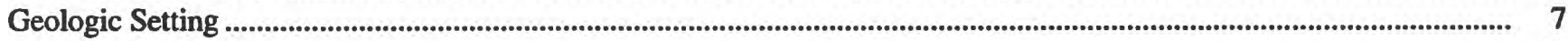

Geologic History........................................................................................................................................ 10

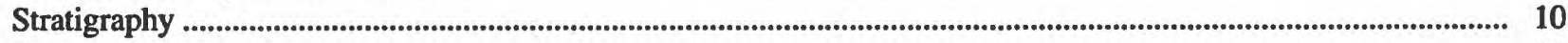

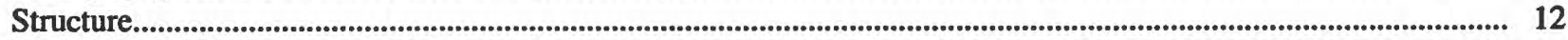

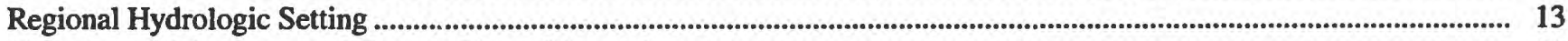

Hydrology of the Saturated Zone at Yucca Mountain ................................................................................................ 16

Hydrogeologic Units................................................................................................................................. 17

Potentiometric Surface .......................................................................................................................... 21

Large Hydraulic Gradient .......................................................................................................... 21

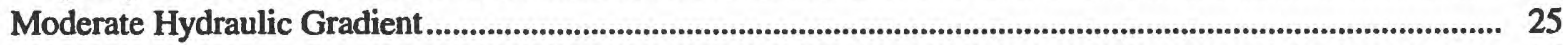

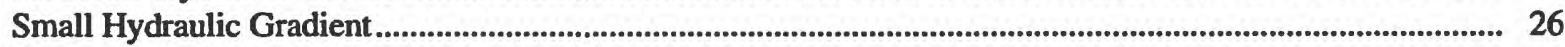

Vertical Hydraulic Gradients ................................................................................................................... 27

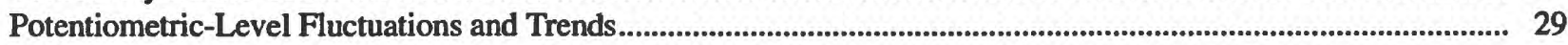

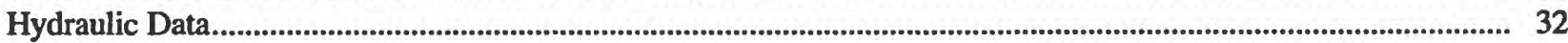

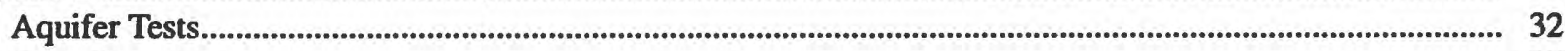

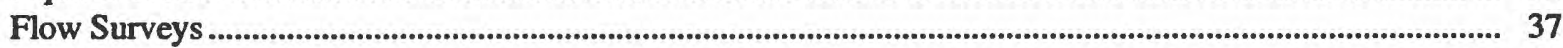

Inflow to Volcanic Flow System ................................................................................................................ 39

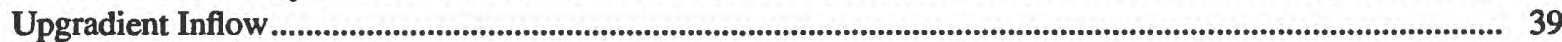

Fortymile Wash Recharge.................................................................................................................. 39

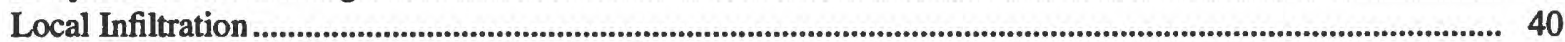

Inflow From the Carbonate Aquifer .............................................................................................. 40

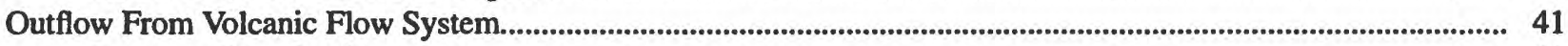

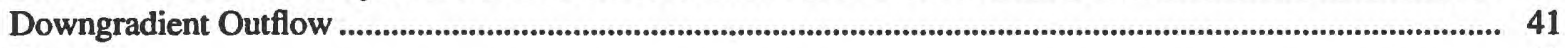

Pumpage ........................................................................................................................................ 41

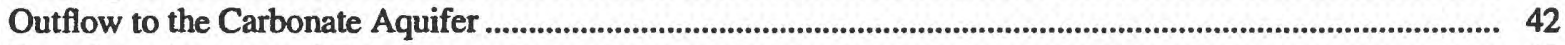

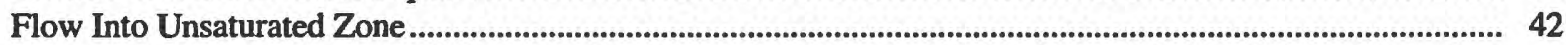

Hydrochemical Data ............................................................................................................................. 42

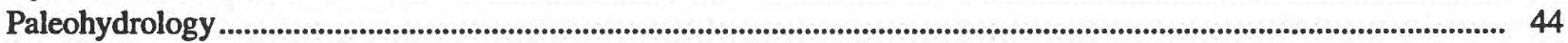

Northern Discharge Deposits...................................................................................................... 45

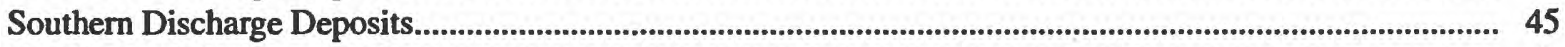

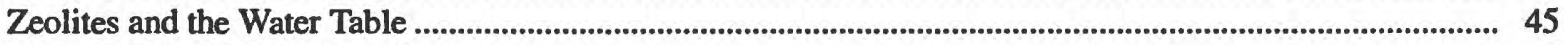

Local Hydrologic Setting (C-Hole Complex) .................................................................................................... 47

Discussion of the Saturated Zone at Yucca Mountain ...................................................................................................... 51

Conceptual Uncertainties............................................................................................................................ 52

Data Uncertainties ................................................................................................................................... 52

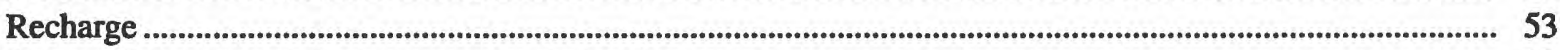

Storage Properties ....................................................................................................................... 53

Transmissive Properties ............................................................................................................ 53

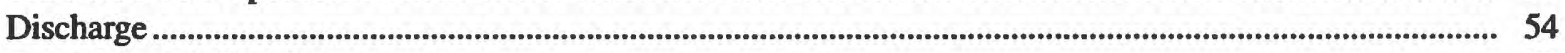

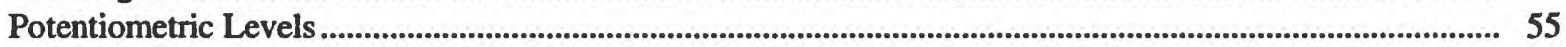


Proposed Simulations

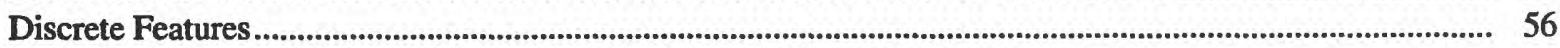

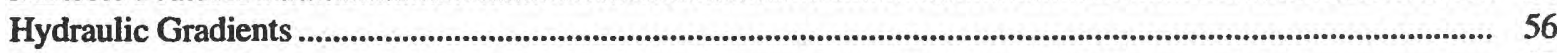

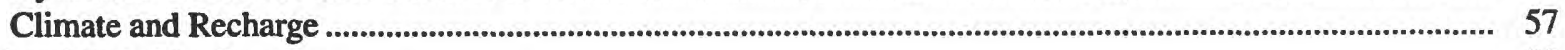

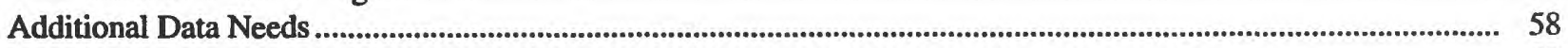

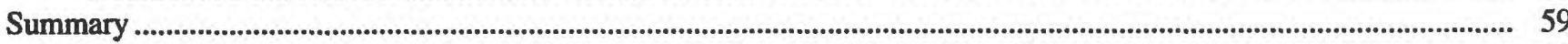

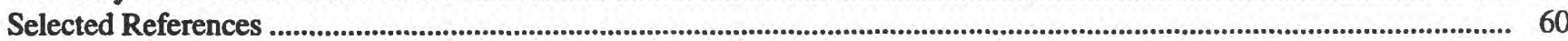

\section{FIGURES}

1-3. Maps showing:

1. Locations of major geographic features in the Death Valley region. A, Death Valley groundwater basin, and $B$, Alkali Flat-Furnace Creek subbasin....................................................................................

2. Locations of southwestern Nevada volcanic field and selected volcanic features ........................................... 8

3. Locations of major geographic features and selected faults in the Yucca Mountain area............................... 9

4. Chart showing selected stratigraphic units in the vicinity of Yucca Mountain that are important to

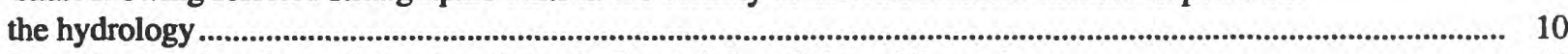

5. Map showing locations of deep boreholes in the vicinity of Yucca Mountain....................................................... 11

6. Map showing potentiometric surface, Death Valley region ......................................................................................... 15

7. Chart showing selected geologic, thermal/mechanical, and hydrogeologic units at Yucca Mountain, Nevada.......................................................................................................................................... 18

8-11. Maps showing:

8. Preliminary potentiometric surface, Yucca Mountain ............................................................................................. 22

9. Revised potentiometric surface of an area of small hydraulic gradient, Yucca Mountain ................................ 23

10. Potentiometric levels in the lower volcanic confining unit and carbonate aquifer.......................................... 26

11. Locations of boreholes in the vicinity of Yucca Mountain in which water levels are monitored ..................... 30

12. Hydrographs showing potentiometric-level fluctuations, 1985-94, for boreholes USW WT-2 and

UE-25 p\#1 at Yucca Mountain ..................................................................................................................................... 31

13. Hydrographs showing response of the potentiometric levels in borehole USW H-6 to earthquakes

at Little Skull Mountain, Nevada, on June 29, 1992 .................................................................................................... 33

14. Map showing locations of aquifer test data at Yucca Mountain......................................................................... 34

15. Flow surveys for selected boreholes in the Yucca Mountain area...................................................................... 38

16. Diagram showing diagenetic zones in the volcanic sequence at Yucca Mountain................................................ 47

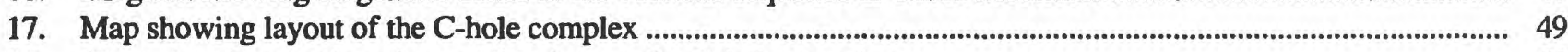

18. Chart showing stratigraphy and lithology at the $\mathrm{C}$-hole complex ............................................................... 50

\section{TABLES}

1. Selected regional stratigraphic and hydrogeologic units in the vicinity of Yucca Mountain ................................ 16

2. Altitudes of hydrogeologic units in deep boreholes at Yucca Mountain ................................................................. 19

3. Potentiometric levels at selected depth intervals in boreholes at Yucca Mountain ............................................. 27

4. Estimated apparent hydraulic-conductivity values obtained from single-borehole aquifer tests in the vicinity of Yucca Mountain

5. Estimated transmissivity values obtained from single-borehole aquifer tests in the vicinity of Yucca Mountain.

6. Boreholes in the vicinity of Yucca Mountain from which hydrochemical data were obtained.

7. Estimates of ground-water discharge at Alkali Flat and Furnace Creek Ranch 


\begin{tabular}{rrll}
\hline & By & & To obtain \\
\hline Multiply & centimeter $(\mathrm{cm})$ & 0.3937 & inch \\
cubic meter $\left(\mathrm{m}^{3}\right)$ & 264.2 & gallon \\
cubic meter per year $\left(\mathrm{m}^{3} / \mathrm{yr}\right)$ & 264.2 & gallon per year \\
kilometer $(\mathrm{km})$ & 0.6214 & mile \\
liter per second $(\mathrm{L} / \mathrm{s})$ & 15.85 & gallon per minute \\
meter $(\mathrm{m})$ & 3.281 & foot \\
meter per day $(\mathrm{m} / \mathrm{d})$ & 3.281 & foot per day \\
meter per kilometer $(\mathrm{m} / \mathrm{km})$ & 5.280 & foot per mile \\
meter per second $(\mathrm{m} / \mathrm{s})$ & 3.281 & foot per second \\
meter per year $(\mathrm{m} / \mathrm{yr})$ & 3.281 & foot per year \\
meter squared per day $\left(\mathrm{m}^{2} / \mathrm{d}\right)$ & 10.76 & foot squared per day \\
millimeter $(\mathrm{mm})$ & 0.03937 & inch \\
millimeter per year $(\mathrm{mm} / \mathrm{yr})$ & 0.03937 & inch per year \\
square kilometer $(\mathrm{km})$ & 0.3861 & square mile \\
\hline
\end{tabular}

Sea level: In this report "sea level" refers to the National Geodetic Vertical Datum of 1929 (NGVD of 1929)-a geodetic datum derived from a general adjustment of the first-order level nets of both the United States and Canada, formerly called Sea Level Datum of 1929. 


\title{
Status of Understanding of the Saturated-Zone Ground-Water Flow System at Yucca Mountain, Nevada, as of 1995
}

\author{
ByRichard R. Luckey, Patrick Tucci, Claudia C. Faunt, Elisabeth M. Ervin, \\ William C. Steinkampf, Frank A. D'Agnese, and Gary L. Patterson
}

\section{Abstract}

Yucca Mountain, which is being studied extensively because it is a potential site for a high-level radioactive-waste repository, consists of a thick sequence of volcanic rocks of Tertiary age that are underlain, at least to the southeast, by carbonate rocks of Paleozoic age. Stratigraphic units important to the hydrology of the area include the alluvium, pyroclastic rocks of Miocene age (the Timber Mountain Group; the Paintbrush Group; the Calico Hills Formation; the Crater Flat Group; the Lithic Ridge Tuff; and older tuffs, flows, and lavas beneath the Lithic Ridge Tuff), and sedimentary rocks of Paleozoic age. The saturated zone generally occurs in the Calico Hills Formation and stratigraphically lower units. The saturated zone is divided into three aquifers and two confining units. The upper volcanic aquifer consists of the densely welded section of the Topopah Spring Tuff of the Paintbrush Group. It is generally saturated only to the west, south, and east of Yucca Mountain. The upper volcanic confining unit consists of the lowermost part of the Topopah Spring Tuff, the Calico Hills Formation, and the uppermost part of the Crater Flat Group. The lower volcanic aquifer consists of most of the Crater Flat Group. The lower volcanic confining unit consists of the Lithic Ridge Tuff and older tuffs, flows, and lavas. The carbonate aquifer consists of a thick sequence of Paleozoic carbonate rocks that may be confined locally by an overlying clastic unit, the Eleana Formation of Mississippian and Late Devonian age.

The flow system at Yucca Mountain is part of the Alkali Flat-Furnace Creek subbasin of the Death Valley ground-water basin. This subbasin is recharged by water from the higher mesas north of Yucca Mountain, and possibly by interbasin inflow, and discharges most, if not all, of its water at Alkali Flat. Variations in the gradients of the potentiometric surface provided the basis for subdividing the Yucca Mountain area into zones of:

(1) large hydraulic gradient where potentiometric levels change at least 300 meters in a few kilometers; (2) moderate hydraulic gradient where potentiometric levels change about 45 meters in a few kilometers; and (3) small hydraulic gradient where potentiometric levels change only about 2 meters in several kilometers. Vertical hydraulic gradients were measured in only a few boreholes around Yucca Mountain; most boreholes had little change in potentiometric levels with depth. The larger vertical gradients measured generally were upward.

Limited hydraulic testing of boreholes in the Yucca Mountain area indicated that the range in transmissivity was more than 2 to 3 orders of magnitude in a particular hydrogeologic unit, and that the average values for the individual hydrogeologic units generally differed by about 1 order of magnitude. The upper volcanic aquifer seems to be the most permeable hydrogeologic unit, but this conclusion was based on exceedingly limited data. 


\section{INTRODUCTION}

The Nuclear Waste Policy Act of 1982 directed the U.S. Department of Energy to conduct a program to find a suitable site to permanently dispose of highlevel radioactive waste in a mined geologic repository. In 1983, the U.S. Department of Energy identified nine potential sites, including Yucca Mountain in southern Nevada (U.S. Department of Energy, 1986, p. 1), which is about $150 \mathrm{~km}$ northwest of Las Vegas (fig. 1). The nine sites were later reduced to three, and in December 1987, the U.S. Congress designated Yucca Mountain as the sole site to be studied as a potential repository site. A $150-\mathrm{km}^{2}$ area enclosing the Yucca Mountain site has been studied extensively since 1978 (Waddell and others, 1984, p. 2) by the U.S. Geological Survey (USGS) and various national laboratories. Yucca Mountain is located in an arid environment; average annual precipitation ranges from about $130 \mathrm{~mm}$ at the base of the mountain to about $170 \mathrm{~mm}$ at the northern part of the crest (D.S. Ambos, Foothill Engineering Consultants, oral commun., 1994). The remote location and the arid environment are two features that make the Yucca Mountain site attractive for disposal of radioactive waste.

Because water would be the primary mechanism for moving most radionuclides away from a geologic repository, a study of the hydrology of a potential site is critical. Only a few radionuclides would move away from a repository in a gaseous phase (Von Konynenburg and others, 1985). Radionuclides could move naturally in ground water, in dissolved, colloidal, or suspended form. Generally, the term "ground water" means water moving through the saturated zone; however, as used for the Yucca Mountain Project and in this report, ground water also includes liquid water moving through the unsaturated, or vadose, zone. The Yucca Mountain Project refers to the collection of various site-characterization and construction activities carried out by the U.S. Department of Energy at Yucca Mountain.

The U.S. Department of Energy is using numerous organizations to carry out scientific studies at Yucca Mountain. The organizations were already involved in scientific studies for the U.S. Department of Energy at the Nevada Test Site when the first boreholes were drilled at Yucca Mountain. These organizations include the USGS, Los Alamos National Laboratory, Lawrence Livermore National Laboratory, and Sandia National Laboratory. The USGS is the lead organization for hydrologic and geologic studies, Los Alamos National Laboratory is the lead organization for geochemical studies, Lawrence Livermore National Laboratory is the lead organization for wastepackage studies, and Sandia National Laboratory is the lead organization for performance assessment studies. Lawrence Berkeley Laboratory is providing support to the USGS in site-scale numerical modeling the unsaturated zone and fracture-flow modeling of the saturated zone. The Bureau of Reclamation, U.S. Department of the Interior, is providing support to the USGS in the area of geologic studies and is providing direct engineering-geology support to the U.S. Department of Energy.

This report was formulated in cooperation with the Yucca Mountain Site Characterization Project, Office of the U.S. Department of Energy under Interagency Agreement DE-AI08-92NV10874.

\section{Historical and Regulatory Background}

In early attempts to find a suitable site for a high-level radioactive-waste repository, virtually all investigations were directed toward saturated sites (U.S. Department of Energy, 1986, p. 5) because the waste would have to be buried deeply. However, when the Great Basin and the area around the Nevada Test Site were evaluated in the 1970's, the thick unsaturated zone was noted. Winograd (1981) recognized that the unsaturated zone in the Great Basin might be suitable for disposal of high-level radioactive waste and discussed a potential area at the Nevada Test Site (not Yucca Mountain). He pointed out that groundwater movement in the unsaturated zone can be extremely slow, and disposal of waste in the unsaturated zone could provide long-term isolation. Another investigator (Roseboom, 1983) pointed out that an unsaturated-zone repository might eliminate many technical problems that could result from disposal in the saturated zone. He also argued that the waste in the unsaturated zone could be fully retrievable for a long period of time. The water table at Yucca Mountain is extremely deep (Robison, 1984, table 1) and the unsaturated zone is up to $750 \mathrm{~m}$ thick.

The concept of multiple barriers to radionuclide migration away from a repository is an important aspect of the study of Yucca Mountain. Multiple barriers include engineered and natural barriers. Engineered barriers include the waste form, the waste 
canister, and any materials introduced in or around the canister. Natural barriers include the geologic units (and their geochemical waste-isolation properties) that radionuclides would have to move through to migrate from the site.

The saturated zone at Yucca Mountain provides the final transport pathway and the last natural barrier between the potential repository and the accessible environment ${ }^{1}$. The saturated zone at Yucca Mountain is considered to be a secondary natural barrier to radionuclide transport (U.S. Department of Energy, 1988, sec. 6.1.5) because ground-water travel time in the saturated zone probably is much shorter than travel time in the unsaturated zone. Because the saturated zone is a secondary barrier, only limited characterization of it may be appropriate. However, flow and transport in the unsaturated zone might be difficult to characterize adequately or the uncertainty of its characterization may be large, whereas characterization of flow and transport in the saturated zone may have less uncertainty and it may be able to be done less expensively. Therefore, the degree to which the saturated zone at Yucca Mountain needs to be characterized remains (in 1996) an open question.

Two major regulatory issues can be addressed in part by characterizing the saturated zone at Yucca Mountain: (1) Ground-water travel time; and (2) releases of radionuclides to the accessible environment. The regulations for a geologic repository (U.S. Nuclear Regulatory Commission, 1986, p. 618-619) include (sec. 113):

The geologic repository shall be located so that pre-waste-emplacement groundwater travel time along the fastest path of likely radionuclide travel from the disturbed zone to the accessible environment shall be at least 1,000 years or such other travel time as may be approved or specified by the [Nuclear Regulatory] Commission.

and (sec. 112):

The geologic setting shall be selected and the engineered barrier system and the shafts, bore-

\footnotetext{
${ }^{1}$ The accessible environment is a regulatory term that includes the atmosphere, land surface, surface water, and all of the lithosphere that is beyond the controlled area. The controlled area is the surface location and the underground area beneath that location that encompasses no more than $100 \mathrm{~km}^{2}$ and extends horizontally no more than $5 \mathrm{~km}$ in any direction from the outer boundary of the original location of the radioactive wastes in a repository (U.S. Department of Energy, 1988, vol. 8, p. G-1 and G-20).
}

holes and their seals shall be designed to assure that releases of radioactive materials to the accessible environment following permanent closure conform to such generally applicable environmental standards for radioactivity as may have been established by the U.S. Environmental Protection Agency with respect to both anticipated processes and events and unanticipated processes and events.

The exact nature of the standards to be set by the U.S. Environmental Protection Agency for the Yucca Mountain site have not yet been determined. The ground-water travel-time issue can be addressed directly by studying the hydrology of the unsaturated and saturated zones once such terms as "likely radionuclide travel" and "disturbed zone," which are part of the regulations, are adequately defined and understood. The issue of releases to the accessible environment, although dependent on hydrology, also is greatly affected by the rate of waste release from the engineered barriers, geochemical retardation by minerals in the rocks, and dispersive and diffusive processes.

\section{Purpose and Scope}

This report documents the status of understanding of the saturated-zone flow system at Yucca Mountain as of 1995. This understanding was developed using the work of a large number of investigators who have studied the saturated-zone hydrology of the Yucca Mountain and the Death Valley region for several decades. The many people who have contributed to the understanding of the flow system at Yucca Mountain are indicated in the "Selected Reference" section. The list of references is extensive, but not exhaustive. It does include all reports that were used in writing this report. In addition to the references, the authors relied heavily on discussions with many USGS investigators, especially I.J. Winograd, W.W. Dudley, Jr., J.H. Robison, M.P. Chornack, R.K. Waddell, and J.B. Czarnecki.

The concepts and information presented in this report are preliminary in that they were developed early in the formal characterization of the saturatedzone flow system at Yucca Mountain that began in 1989. Formal characterization began after detailed planning for that characterization was completed. This report relies, in large part, on data collected in the 1970 's and 1980's before formal characterization 


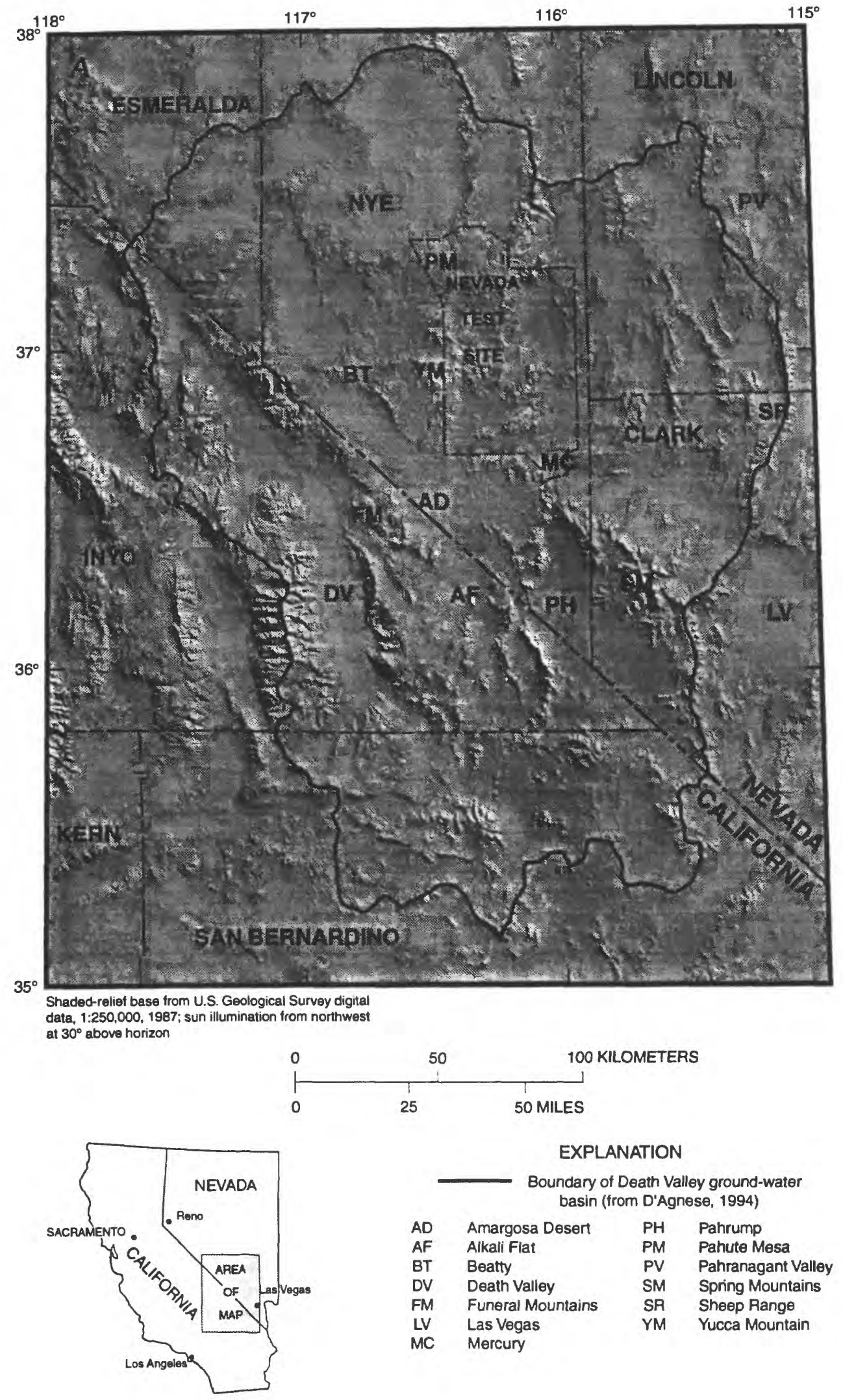

Figure 1. Locations of major geographic features in the Death Valley region. $A$, Death Valley ground-water basin, and $B$, Alkali Flat-Furnace Creek subbasin. 
$116^{\circ} 00^{\prime}$

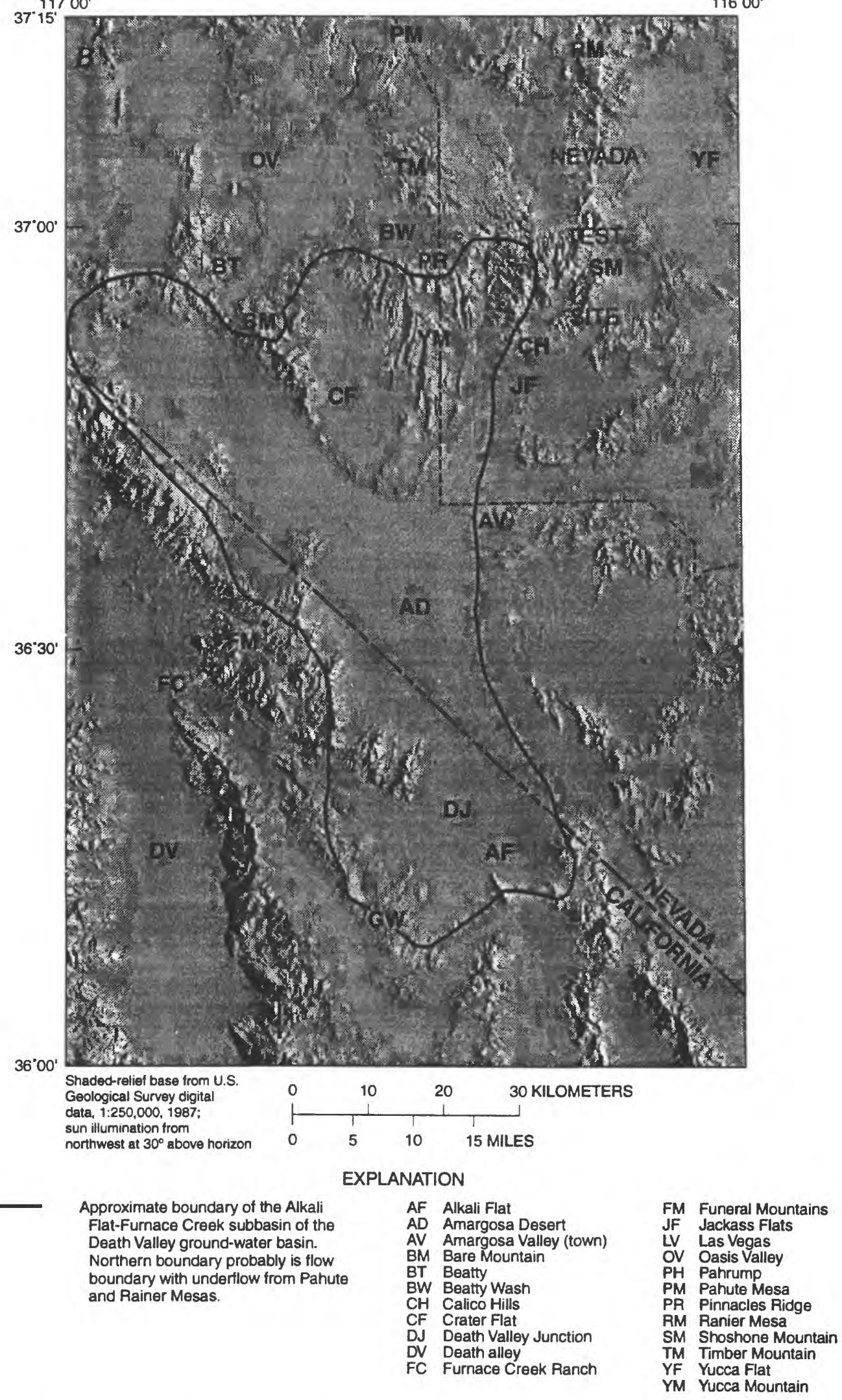

Figure 1. Locations of major geographic features in the Death Valley region. $A$, Death Valley ground-water basin, and $B$, Alkali Flat-Furnace Creek subbasin-Continued. 
began in 1989 because only limited characterization of the saturated zone has been done since 1989 .

The emphasis of this report is on the saturatedzone flow system in the loosely defined area discussed in the "Hydrology of the Saturated Zone at Yucca Mountain" section. Although the report emphasizes the site-scale flow system, it also describes the regional flow system in some detail to put the sitescale flow system into perspective. In addition, some small-scale (within tens of meters) effects observed at a multiple-borehole complex are described. This local-scale study will help define the complexities and variability of the flow system at individual points within the site area. Transport characteristics, including the associated geochemical, dispersive, and diffusive processes, are beyond the scope of this report.

Although some components of the ground-water flow system (such as the configuration of the potentiometric surface in an area of small hydraulic gradient) are fairly well defined as of 1995 , other components (such as the cause of a large hydraulic gradient) are not well understood. This report also documents the level of understanding and defines major uncertainties about the flow system. The report indicates areas where more information is needed for an adequate or even elementary understanding of the flow system. This report is intended to lay a foundation for the creation of numerical models of the saturated-zone ground-water flow system at Yucca Mountain, but it does not discuss detailed formulation of numerical models. It does, however, suggest how numerical models may be used to fully test various hypotheses about the flow system and to improve the understanding of the flow system.

\section{Previous Work}

The first comprehensive study of the hydrology of the Nevada Test Site and surrounding areas was reported by Winograd and Thordarson (1975). Their report included: (1) A study of regional flow through carbonate rocks that underlie much of southern Nevada; (2) a study of volcanic rocks in the area of underground nuclear-weapons testing at Yucca Flat; (3) a study of the hydrochemistry of water throughout the area; and (4) identification of potential hydrologic barriers and their effects on ground-water flow. A broader regional, although less intense, study is contained in Bedinger and others (1984). Montazer and Wilson (1984) described a conceptual model of ground-water flow in the unsaturated zone beneath Yucca Mountain; Czarnecki (1989a) and Czarnecki and Wilson (1991) summarized regional ground-water flow germane to Yucca Mountain using conceptual models. Downey and others (1990) discussed various criteria for delimiting boundaries of the regional flow system. Other hydrologic reconnaissance studies that described the regional flow system include Eakin and others (1963), Walker and Eakin (1963), Rush (1970), Waddell (1982), Waddell and others (1984), Czarnecki (1990), Kilroy (1991), and Oatfield and Czarnecki (1991).

Several numerical models at various scales were developed to describe the saturated-zone flow system in the vicinity of Yucca Mountain. Modeling was done for the area of the Nevada Test Site and vicinity by Oberlander (1979), Waddell (1982), Rice (1984), and Sinton (1987). Waddell (1982) and Rice (1984) examined two-dimensional areal ground-water flow, whereas Sinton (1987) incorporated the third dimension (depth) in a quasi-three dimensional application of the MODFLOW computer program (McDonald and Harbaugh, 1988). D'Agnese (1994) constructed a three-dimensional numerical model of much of southern Nevada and adjacent eastern California using the hydrogeologic framework developed by Faunt (1994).

Czarnecki and Waddell (1984) developed a twodimensional parameter-estimation model to estimate values of transmissivity throughout the ground-water subbasin that includes Yucca Mountain. Czarnecki (1985) used the same finite-element grid to estimate the effects of increased recharge on water-table altitude and on direction of ground-water flow. Additional simulations by Czarnecki (1989b, 1991) analyzed the effects of abrupt changes in hydraulic conductivity in the vicinity of a large hydraulic gradient and the effects of increases in recharge on the flow system. A cross-sectional model was developed by Haws (1990) along a flow path constructed from the flow-field vectors of Czarnecki and Waddell (1984). Modeling by Carrigan and others (1991) analyzed potential excursions of the water table at Yucca Mountain that could be produced by seismic events. Models developed by Ahola and Sagar $(1992,1993)$ and Dressel (1992) were used to analyze the effects of changes in hydraulic properties and recharge on watertable altitudes in the flow system.

Barr and Miller (1987) developed a model of ground-water flow in the vicinity of Yucca Mountain 
to use for the saturated-zone facets of performanceassessment modeling to determine if the regulatory requirements for a geologic repository could be met. Buscheck and Nitao $(1992,1993,1995)$ reported on the possible effects of heat from a repository on ground-water flow in the unsaturated and saturated zones. Barr and others (Chapter $\mathbf{1 1}$ of Wilson and others, 1994) developed a three-dimensional model at the site scale to support performance-assessment calculations.

Numerous geophysical surveys were done in the vicinity of Yucca Mountain (Oliver and others, 1995), largely for the characterization of its geology. Magnetic surveys were reported on by Kane and others (1981), Kane and Bracken (1983), Bath and Jahren (1984), Glen and Ponce (1991), Langenheim (1995), Ponce and Langenheim (1995), and Ponce and others (1995). Regional gravity surveys were reported by Healey and Miller (1971), Snyder and Carr (1982), Healey and others (1987), and Ponce and others (1988). Electrical-resistivity surveys were reported by Flanigan (1981), Greenhaus and Zablocki (1982), and Senterfit and others (1982). Seismic surveys were reported by Pankratz (1982) and Brocher and others (1993, 1996). Borehole-geophysical surveys were described by Daniels and others (1981), Muller and Kibler (1984), Stock and others (1984), and Nelson and others (1991); this latter report contained geophysical logs from 40 boreholes. Boreholetemperature surveys, used to calculate crustal-heat flow and to infer ground-water flow and direction, were discussed by Sass and Lachenbruch (1980) and Sass and others (1988). Overviews of various geophysical surveys were discussed by Carr and Yount (1988) and Oliver and others (1991).

Characterizations of the geology from boreholes constructed at or near Yucca Mountain were discussed by Spengler and others $(1979,1981,1984)$, Spengler and Rosenbaum (1980), Carr (1982), Maldonado and Koether (1983), Carr and Parrish (1985), and Carr, M.D., and others (1986). Geologic syntheses were produced by Carr (1984), Scott and Bonk (1984), Scott and others (1984), Robinson (1985), Carr, W.J., and others (1986), Swadley and Carr (1987), Carr and Yount (1988), Swadley and Parrish (1988), Swadley and Hoover (1989), and Diehl and Chornack (1990). Sawyer and others (1994) published a revised stratigraphic nomenclature for the volcanic rocks of the area that includes Yucca Mountain; their nomenclature is used in this report.
Water-level surveys and measurements at or near Yucca Mountain were described by Fenske and Carnahan (1976), Robison (1984), Waddell and others (1984), Robison and others (1988), Gemmell (1990), Kilroy (1991), O'Brien (1991, 1992), Luckey and others (1993), Boucher (1994a), Ciesnik (1995), Lobmeyer and others (1995), O'Brien and others (1995), and Tucci and others (in press).

Hydraulic-test results and analyses from boreholes at or near Yucca Mountain were reported by Bentley and others (1983), Craig and others (1983), Lobmeyer and others (1983), Thordarson (1983), Bentley (1984), Craig and Johnson (1984), Craig and Robison (1984), Rush and others (1984), Thordarson and others (1984), Waddell (1984), Whitfield and others (1984; 1985), Erickson and Waddell (1985), Galloway and Erickson (1985), Thordarson and others (1985), Lobmeyer (1986), Craig and Reed (1991), Robison and Craig (1991), and Geldon (1993).

Hydrochemical and isotopic data and analyses from boreholes at or near Yucca Mountain were reported by Winograd and Thordarson (1975), Benson and others (1983), Benson and McKinley (1985), Claassen (1985), Kerrisk (1987), McKinley and others (1991), Stuckless, Whelan, and Steinkampf (1991), Thomas and others (1991), and Perfect and others (1995).

\section{GEOLOGIC SETTING}

Yucca Mountain is located in the Great Basin section of the Basin and Range physiographic province (Snyder and Carr, 1982), which is characterized by generally linear, north-trending mountain ranges separated by intervening basins. Yucca Mountain is in the southern part of the southwestern Nevada volcanic field of Miocene age (Byers and others, 1976; Sawyer and others, 1994) (fig. 2). Yucca Mountain consists of a group of north-trending block-faulted ridges that are composed of volcanic rocks of Tertiary age that may be several kilometers thick (Snyder and Carr, 1984, table 1). Yucca Mountain extends northward to Pinnacles Ridge (fig. 1) at the southern end of the Claim Canyon caldera and southward to approximately U.S. Highway 95 (fig. 2) at the northern edge of the Amargosa Desert. Jackass Flats, an alluviumfilled basin with exterior drainage to the south, is east of Yucca Mountain and is separated from Yucca Mountain by Fortymile Wash (fig. 3). The basin to the 


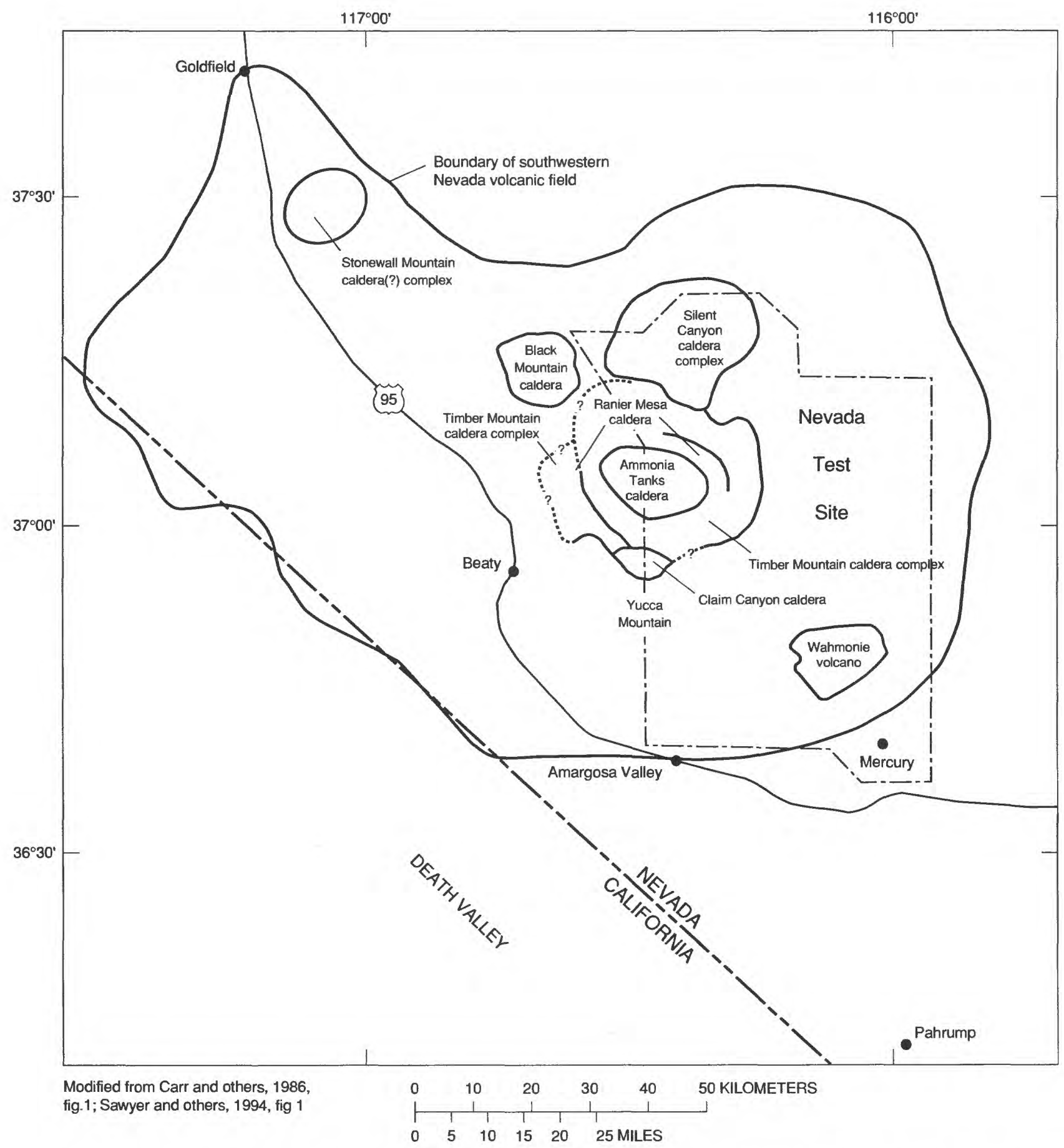

Figure 2. Locations of southwestem Nevada volcanic field and selected volcanic features (modified from Carr and others, 1986 and Sawyer and others, 1994). 


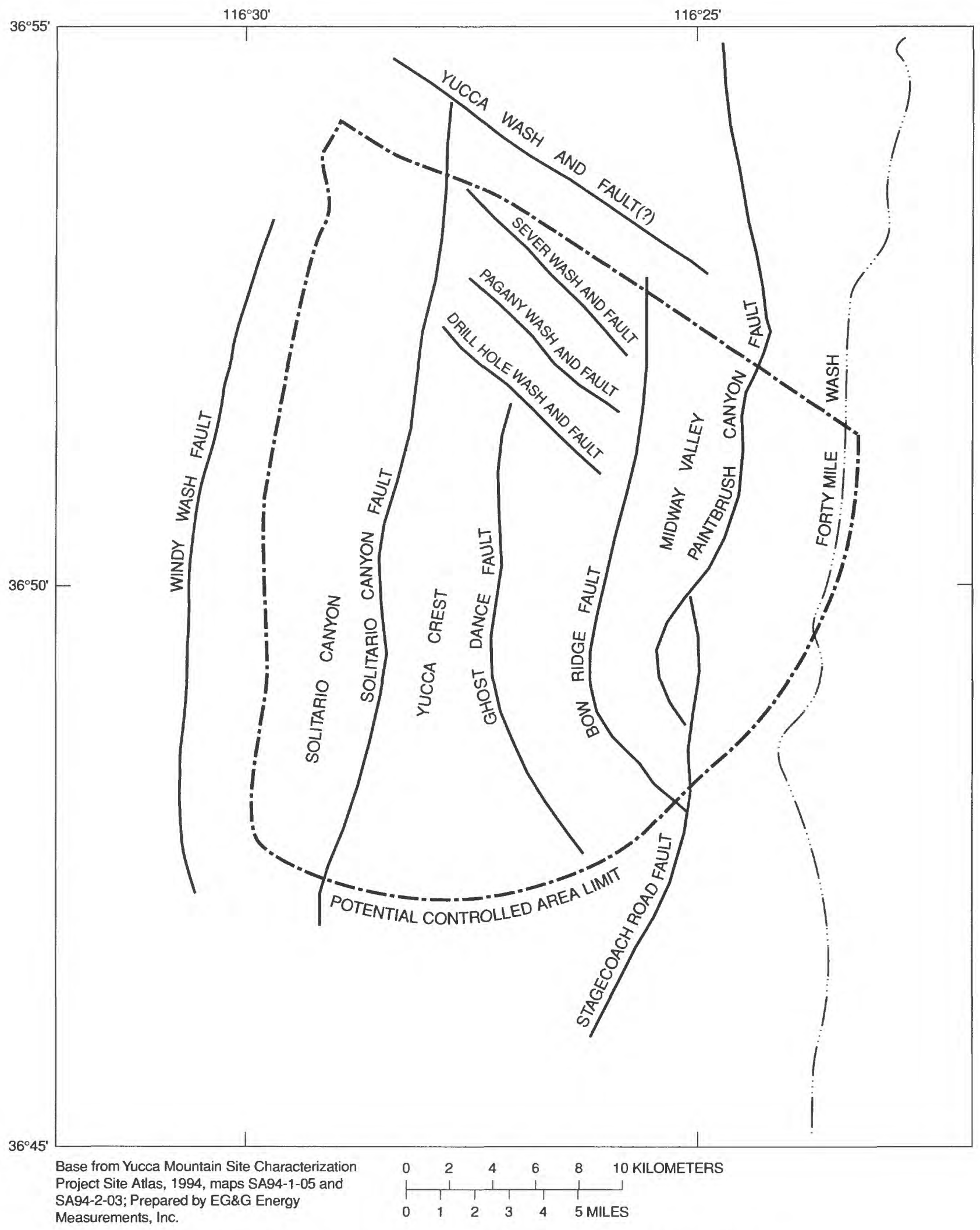

Figure 3. Locations of major geographic features and selected faults in the Yucca Mountain area. 
west of Yucca Mountain is Crater Flat (fig. 1), which contains a thick sequence of Tertiary volcanic rocks, alluvium, and small basaltic lava flows of Quaternary age. Crater Flat is separated from Yucca Mountain by Solitario Canyon (fig. 3), which is formed along the trace of a steeply dipping normal-fault feature.

Timber Mountain (fig. 1), located $25 \mathrm{~km}$ to the north of Yucca Mountain, is the surface expression of a resurgent dome in a large caldera complex (Byers and others, 1976; Sawyer and others, 1994). Pahute Mesa, about $40 \mathrm{~km}$ to the north of Yucca Mountain, and Rainier Mesa, about $35 \mathrm{~km}$ to the north-northeast, are higher altitude plateaus that consist of a sequence of pyroclastic flows and fallout deposits and tuffaceous sedimentary rocks of Tertiary age (Byers and others, 1976). Approximately $25 \mathrm{~km}$ to the south is Alkali Flat (Franklin Lake Playa) ${ }^{2}$. Between Yucca Mountain and Alkali Flat is the alluvium-filled Amargosa Desert, a northwest-southeast-trending valley.

\section{Geologic History}

The topography of Yucca Mountain resulted from faulting and erosion of an extensive volcanic plateau created by the deposition of a thick sequence of pyroclastic rocks of Miocene age. Extensional tectonics occurring between $17 \mathrm{Ma}$ (million years before present) and $11 \mathrm{Ma}$ formed the basin and range topography that characterizes much of the surrounding area. The silicic volcanic rocks were erupted between $15 \mathrm{Ma}$ and $7 \mathrm{Ma}$ from the southwestern Nevada volcanic field (fig. 2). Yucca Mountain is located in the southeastern part of the volcanic field. Except for surficial erosion and minor displacement on existing faults, the topography of Yucca Mountain has changed very little since the cessation of major faulting approximately 12 Ma (Carr, 1988, p. 40; Huber, 1988).

\footnotetext{
${ }^{2}$ The two names of this geographic feature are used in this report because both names have been used in hydrologic reports to identify this feature. Most modern maps call this feature Alkali Flat. However, because there are numerous places called Alkali Flat in the Great Basin, some authors have used the term "Franklin Lake Playa," which appeared on some very early maps. Both terms are used together throughout this report to avoid confusion.
}

\section{Stratigraphy}

The stratigraphic section at Yucca Mountain consists of a thick sequence of Tertiary pyroclastic rocks overlying sedimentary and possibly igneous intrusive rocks of Paleozoic age (fig. 4) (Snyder and Carr, 1982). Data from deep boreholes and geophysical studies indicated that Tertiary volcanic rocks were more than 2,000 m thick in much of the area around Yucca Mountain and, in some places, were as much as 3,050 m thick (Snyder and Carr, 1984, p. 10193 and table 1). The Tertiary volcanic rocks at Yucca Mountain consist of pyroclastic flow and fallout deposits, lava flows, and volcanic breccias of Miocene age. The tuffs at Yucca Mountain are primarily nonwelded to densely welded, vitric to devitrified pyroclastic-flow deposits separated by nonwelded, vitric fallout deposits. These deposits are laterally continuous and fairly homogeneous throughout the Yucca Mountain area. Rhyolitic to dacitic lava flows, in addition to tuffs, were penetrated both above and beneath the Lithic Ridge Tuff in boreholes USW G-1 and USW G-2 (fig. 5), but are not laterally extensive throughout the area.

\begin{tabular}{|c|c|c|}
\hline Period & \multicolumn{2}{|c|}{ Statigraphic Unit } \\
\hline Quaternary & \multicolumn{2}{|c|}{ Alluvium } \\
\hline \multirow{11}{*}{ Tertiary } & $\begin{array}{l}\text { Timber Mountain } \\
\text { Group }\end{array}$ & Ranier Mesa Tuff \\
\hline & \multirow{4}{*}{$\begin{array}{l}\text { Paintbrush } \\
\text { Group }\end{array}$} & Tiva Canyon Tuff \\
\hline & & $\begin{array}{c}\text { Yucca Mountain } \\
\text { Tuff }\end{array}$ \\
\hline & & Pah Canyon Tuff \\
\hline & & $\begin{array}{c}\text { Topapah Spring } \\
\text { Tuff }\end{array}$ \\
\hline & \multicolumn{2}{|c|}{ Calico Hills Formation } \\
\hline & \multirow{3}{*}{$\begin{array}{l}\text { Crater Flat } \\
\text { Group }\end{array}$} & Prow Pass Tuff \\
\hline & & Bullfrog Tuff \\
\hline & & Tram Tuff \\
\hline & \multicolumn{2}{|c|}{ Lithic Ridge Tuff } \\
\hline & \multicolumn{2}{|c|}{ Older tuffs, lavas, and breccias } \\
\hline $\begin{array}{l}\text { Early Permian and } \\
\text { Pennsylvanian }\end{array}$ & \multicolumn{2}{|c|}{ Tippipah Limestone } \\
\hline $\begin{array}{l}\text { Mississippian and } \\
\text { Late Devonian }\end{array}$ & \multicolumn{2}{|c|}{ Eleana Formation } \\
\hline $\begin{array}{c}\text { Devonian to } \\
\text { Cambrian }\end{array}$ & \multicolumn{2}{|c|}{$\begin{array}{l}\text { Undifferentiated, primarily } \\
\text { carbonate rocks }\end{array}$} \\
\hline Cambrian & \multicolumn{2}{|c|}{$\begin{array}{l}\text { Undifferentiated, primarily } \\
\text { clastic rocks }\end{array}$} \\
\hline
\end{tabular}

Figure 4. Selected stratigraphic units in the vicinity of Yucca Mountain that are important to the hydrology (Tertiary nomenclature modified from Sawyer and others, 1994). 


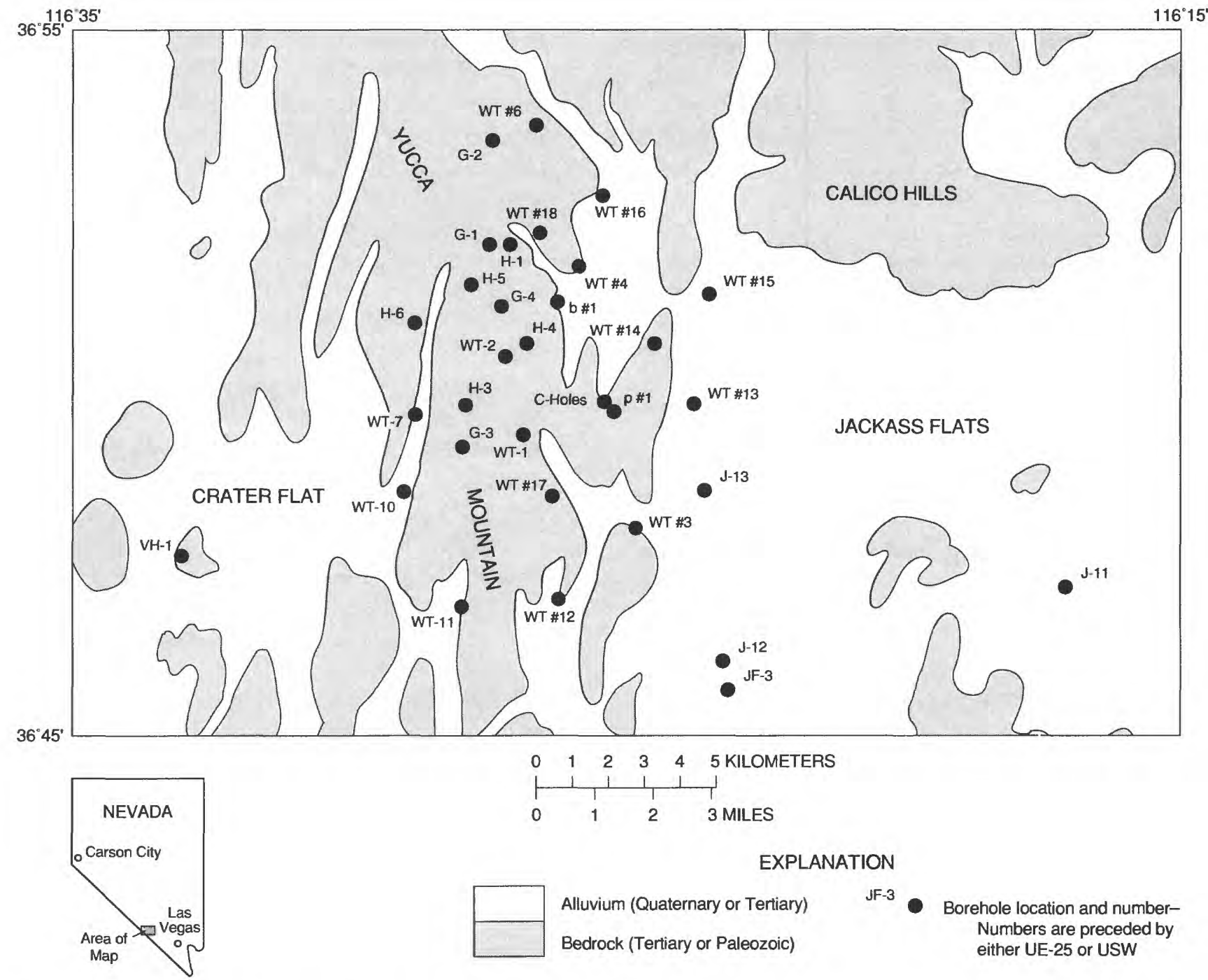

Figure 5. Locations of deep boreholes in the vicinity of Yucca Mountain.

Borehole UE-25 p\#1, situated on a gravity high that was interpreted to be a local minimum depth to pre-Tertiary rocks (Carr, M.D., and others, 1986, p. 7), was drilled to the east of Yucca Mountain. This borehole penetrated Paleozoic carbonate rocks at a depth of 1,244 m (Carr, M.D., and others, 1986, table 2). A fault contact separates the Tertiary and Paleozoic rocks in this borehole. Regional geologic and geophysical data compiled and interpreted by Robinson (1985, pl. 1 and fig. 9) indicated that Paleozoic sedimentary rocks subcrop on the pre-Tertiary surface beneath Yucca Mountain and dip generally northward. Robinson's interpretation indicated that the carbonate aquifer underlies the Yucca Mountain site and that the Eleana Formation of Mississippian and Late Devonian age, a confining unit, underlies northern Yucca Mountain.

The rocks exposed at the surface of Yucca Mountain consist of formations of the Paintbrush Group with minor outcrops of the Rainier Mesa Tuff of the Timber Mountain Group (Scott and Bonk, 1984; Sawyer and others, 1994). The Paintbrush Group was erupted from the Claim Canyon caldera, approximately $12 \mathrm{~km}$ to the north of Yucca Mountain, between 12.7 $\mathrm{Ma}$ and 12.8 $\mathrm{Ma}$ (Sawyer and others, 1994). The Rainier Mesa Tuff was erupted 11.6 Ma (Sawyer and others, 1994) from the Rainier Mesa caldera. The younger Rainier Mesa Tuff was deposited in the vicinity of Yucca Mountain in structurally 
controlled valleys that formed after the deposition of the Paintbrush Group.

The formations of the Paintbrush Group, in descending order, are the Tiva Canyon Tuff, the Yucca Mountain Tuff, the Pah Canyon Tuff, and the Topopah Spring Tuff. The Tiva Canyon Tuff is a compositionally zoned ash-flow tuff as defined by Ross and Smith (1961). It is laterally extensive near Yucca Mountain and includes an area in excess of $2,600 \mathrm{~km}^{2}$ (Byers and others, 1976). The Yucca Mountain Tuff and Pah Canyon Tuff are small-volume ash flows (Byers and others, 1976) and are not laterally extensive. Near Yucca Mountain, the distal edges of these units are included in the bedded tuffs. The bedded tuffs are exposed in many of the deeper washes and adjacent to faults. The Topopah Spring Tuff, a compositionally zoned ash-flow tuff (Lipman and others, 1966), is the thickest member of the Paintbrush Group in the Yucca Mountain area and is laterally extensive at Yucca Mountain.

The principal units composing the volcanic stratigraphy beneath the Paintbrush Group at Yucca Mountain are, in descending order, the Calico Hills Formation (principally nonwelded tuffs), the Prow Pass, Bullfrog, and Tram Tuffs of the Crater Flat Group, the Lithic Ridge Tuff, and older unnamed ashflow tuffs, lavas, and breccias (Carr, W.J., and others, 1986). These units are mainly pyroclastic flow deposits that are separated by bedded, pyroclastic-fall deposits and occasionally by localized lava flows. Diagenetic alteration resulting from the interaction between the volcanic glass and ground water has produced zones of zeolitization and clay alteration in the vitric, nonwelded to partially welded pyroclastic rocks.

\section{Structure}

Structures of Cenozoic age having surface expressions at and near Yucca Mountain are: (1) normal faults, (2) strike-slip faults, and (3) volcanotectonic structures (Scott and others, 1983, p. 297). In addition to these Cenozoic structures, older low-angle faults have been identified at the land surface in the vicinity of Yucca Mountain (Maldonado, 1985).

Normal faulting, the first type of Cenozoic structure related to basin and range extensional tectonics, began approximately $18 \mathrm{Ma}$ and major activity ended prior to or shortly after the deposition of the Timber Mountain Group around 11.4 Ma (Noble and others, 1990). The normal faults at Yucca Mountain dip steeply to the west. The blocks bounded by these faults have been rotated to the east from 5 to $10^{\circ}$ (Carr, 1984, p. 66). Displacements on the faults range from less than $1 \mathrm{~m}$ on individual fault traces in imbricate fault zones to more than $300 \mathrm{~m}$ on the Solitario Canyon Fault (fig. 3) (Carr, 1984, fig. 30). The spacing between major north-striking normal faults at Yucca Mountain ranges from 0.5 to $2.0 \mathrm{~km}$ (Carr, 1984, p. 66; Frizzell and Shulters, 1990). The zone of disruption adjacent to the normal faults varies from thin brecciation along fault planes to broken and brecciated zones that are many tens of meters wide (Spengler and others, 1993; Spengler and others, 1994). The geometry of the normal faults and of the strike-slip faults controls much of the topography and drainage development at Yucca Mountain.

Northwest-striking strike-slip faults that have right-lateral movement are the second type of Cenozoic structures present at Yucca Mountain (Scott and others, 1984). Strike-slip faulting has been linked to tectonic activity in the Walker Lane Belt, which is a large northwest-trending structural zone that parallels most of the southwest border of Nevada. The Las Vegas Valley shear zone is part of the Walker Lane Belt between Las Vegas and Indian Springs, Nevada (Carr, 1984, p. 9-12). Movement on the northweststriking strike-slip faults apparently diminished and, in some places, ceased after the deposition of the Timber Mountain Group (Scott and others, 1984, p. 19). The structural blocks near Yucca Mountain that are bounded by the strike-slip faults generally are tilted approximately $5^{\circ}$ east-southeast to southeast. Vertical offset on these faults is minor (Scott and others, 1984, p. 18); no obvious offsets are present at the land surface. Major washes and drainage patterns, such as Yucca Wash and Pagany Wash (fig. 3), developed parallel to the strike-slip faults (Scott and others, 1984).

Volcano-tectonic features (Scott and others, 1983; Carr, 1990) are the third type of Cenozoic structures in the Yucca Mountain area and are related to caldera formation and volcanic activity. Generally, circular or semicircular faults are coincident with the surficial expression of the boundary of a caldera. Near Yucca Mountain, these types of faults are located to the north in the vicinity of the boundary of the Timber Mountain caldera complex (fig. 2).

The evidence for low-angle faulting near Yucca Mountain is east in the Calico Hills and west at Bare 
Mountain (fig. 1). In the Calico Hills, low-angle faults have been mapped in the Paleozoic-age rocks and between the Paleozoic sedimentary rocks and the Tertiary volcanic rocks (Maldonado, 1985). The lowangle fault contact between the Paleozoic and Tertiary rocks in the Calico Hills has been interpreted as an extensional feature by Simonds and Scott (1987). Extensional faulting is present between the Paleozoic and Tertiary rocks at the northern end of Bare Mountain (Carr and Monsen, 1988).

\section{REGIONAL HYDROLOGIC SETTING}

Although the geology, unsaturated-zone hydrology, and saturated-zone hydrology of the $150-\mathrm{km}^{2}$ area around Yucca Mountain is being studied intensively, regional geologic and hydrologic studies also are needed. Understanding the regional saturated-zone flow system, at least in general terms, is necessary to understanding the saturated-zone flow system in the immediate vicinity of Yucca Mountain. General concepts learned from the regional flow system could be applied to the flow system at Yucca Mountain. More specifically, regional numerical flow models are needed to define boundary conditions for numerical models that need to be developed for the saturatedzone flow system at the scale of Yucca Mountain.

The saturated-zone flow system at Yucca Mountain is part of the Alkali Flat-Furnace Creek groundwater subbasin as described by Waddell (1982) and is a segment of the larger Death Valley ground-water flow system (Bedinger, Sargent, and Langer, 1989; D'Agnese, 1994) (fig. 1). In this report, the regional scale refers to the Death Valley flow system, an area of about $47,000 \mathrm{~km}^{2}$. The subregional scale refers to that part of the Death Valley flow system that discharges at Alkali Flat (Franklin Lake Playa) in the southern Amargosa Desert. The subregional flow-system boundary continues to evolve, and the boundary does not necessarily coincide with the boundary used by Waddell (1982). As will be discussed in the "Data Uncertainties-Discharge" section, the subregional system may not include the Furnace Creek discharge area. The site scale for geologic and unsaturated-zone hydrologic studies refers to an approximately $150-\mathrm{km}^{2}$ area around the potential repository at Yucca Mountain. However, because there are no natural hydrologic boundaries in the saturated zone at the site scale, the discussion of the site-scale saturated-zone flow system needs to extend beyond the $150-\mathrm{km}^{2}$ area generally considered the site scale.

The Death Valley ground-water basin as defined by Bedinger, Sargent, and Langer (1989) includes several subbasins, each of which has a particular discharge area and generally is named after its discharge area. The boundaries of the Death Valley groundwater basin and its subbasins are not precisely known, and the subbasins may exchange water with other subbasins through subsurface underflow. The boundaries between the Death Valley ground-water basin and adjoining basins and boundaries between the subbasins were selected using inferred no-flow or limitedflow boundaries. No-flow boundaries were based on postulated ground-water divides or were placed along inferred flow paths because no flow was assumed to occur perpendicular to the flow paths. Limited-flow boundaries were selected where the flow across the boundary was assumed to be small compared to flow through the basin or subbasin.

Yucca Mountain is centrally located in the Death Valley ground-water basin and also is centrally located in the Alkali Flat-Furnace Creek subbasin (fig. 1). The subbasin receives water from recharge within its boundaries and probably also receives water as underflow from adjoining subbasins. Ground water leaves the subbasin as evapotranspiration at discharge areas or as interbasin outflow.

Recharge within the Death Valley ground-water basin probably occurs at higher altitudes where there is more precipitation. In the vicinity of Yucca Mountain, recharge from precipitation probably occurs at Timber Mountain, Pahute Mesa, Rainier Mesa, Shoshone Mountain, and the Spring Mountains (fig. 1). Some water may enter the Death Valley ground-water basin by subsurface flow from Pahranagant Valley (fig. 1) on the northeastern boundary of the basin (Winograd and Thordarson, 1975, p. 110-111). Closer to Yucca Mountain, infiltration of runoff in Fortymile Canyon and Fortymile Wash probably contributes recharge to the Death Valley flow system (Claassen, 1985; Savard, 1994). Ground water flows through Quaternary, Tertiary, and Paleozoic aquifers to discharge areas. The discharge areas for the Death Valley ground-water basin include, among others, Ash Meadows, Alkali Flat (Franklin Lake Playa), Oasis Valley, and Death Valley. Death Valley is the ultimate ground-water discharge area and is a closed basin; that is, no water leaves it as surface or subsurface flow. 
Winograd and Thordarson (1975, pl. 1) constructed a partial potentiometric-surface map of the Nevada Test Site and vicinity. Their map allowed for flow from Pahute Mesa in the north of Yucca Mountain to the Amargosa Desert in the south of the mountain. However, they had no data for the intervening Timber Mountain area, and they omitted contours which might imply that they knew flow occurred through this area. In constructing the first numerical model of the Alkali Flat-Furnace Creek subbasin and the adjacent subbasins, Waddell (1982, fig. 3) produced a more complete potentiometric-surface map of the region although he also had no data for the Timber Mountain area. Waddell's (1982) potentiometricsurface map indicated southward flow from Pahute Mesa, beneath the Timber Mountain and Yucca Mountain areas, then southward beneath the Amargosa Desert to Alkali Flat (Franklin Lake Playa) and into Death Valley. Czarnecki and Waddell (1984, fig. 3) constructed a potentiometric-surface map of the Yucca Mountain area from Timber Mountain into the Amargosa Desert, using data not available to earlier investigators. They had a considerable number of data points in the immediate vicinity of Yucca Mountain, but they still had little data north of Yucca Mountain and no data for the Timber Mountain area. Czarnecki and Waddell (1984) also indicated a general flow from north to south with implied water levels more than $1,140 \mathrm{~m}$ above sea level in the Timber Mountain area to less than $660 \mathrm{~m}$ at Alkali Flat. D'Agnese (1994, fig. 10-3), produced a potentiometric-surface map of the Death Valley ground-water basin using newer information not available to previous investigators. He too indicated flow from Pahute Mesa, beneath Yucca Mountain, and then to the Amargosa Desert and beyond. However, he also was hampered by a lack of data in the Timber Mountain area. A slightly modified version of D'Agnese's (1994) map is shown in figure 6.

Existing potentiometric data for the region around Yucca Mountain indicated a generally southerly flow of ground water from upland recharge areas of Pahute Mesa and Rainier Mesa (water-table altitudes of about $1,400 \mathrm{~m}$ ) and southward to Yucca Mountain (water-table altitude of about $730 \mathrm{~m}$ ). Numerical modeling results (Waddell, 1982; Czarnecki and Waddell, 1984; Rice, 1984; Sinton, 1989; D'Agnese, 1994) have been consistent with this general direction of flow. Because of uncertainties due to a lack of data, alternative conceptual models of flow from upland areas to the north to Yucca Mountain are discussed in the "Upgradient Inflow" section.

In the vicinity of Yucca Mountain, ground water flows in a southerly direction to basin-fill sediments (valley-fill aquifer of Winograd and Thordarson, 1975, table 1) and lacustrine carbonate rocks underlying the Amargosa Desert. Potentiometric and hydrochemical data indicated that ground water flows in a southerly direction beneath the Amargosa Desert toward Alkali Flat (Franklin Lake Playa). Discharge at the playa occurs primarily through evapotranspiration. Some ground water may flow beneath the mountain at the south end of the playa and continue on southward. Some ground water also may flow in a southwesterly direction from the Amargosa Desert beneath the Funeral Mountains to discharge as spring flow and evapotranspiration in the vicinity of Furnace Creek Ranch.

Potentiometric data also indicated that a groundwater divide may exist to the south of the Funeral Mountains in the Greenwater Range, between the Amargosa Desert and Death Valley (Czarnecki and Wilson, 1991, p. 18), at least for the relatively shallow hydrologic system. If a ground-water divide does exist beneath the Greenwater Range and the Funeral Mountains to the north, flow through the Alkali FlatFurnace Creek subbasin, and hence flow through the Yucca Mountain area, may be substantially less then postulated by previous modeling (Waddell, 1982, table 4; Czarnecki and Waddell, 1984, pl. 2).

Deep hydraulic connection through the carbonate aquifer may connect the Ash Meadows area on the east side of the Amargosa Desert to the Furnace Creek Ranch area of Death Valley. This possible connection is consistent with the observation that the hydrochemistry of water from springs that discharge at Furnace Creek Ranch is similar to the hydrochemistry of water discharging at some springs in the Ash Meadows area (Winograd and Thordarson, 1975, p. 95-97). This similarity in hydrochemistry allows the possibility of westward ground-water flow through deep aquifers beneath the Amargosa Desert whereas flow through the shallower aquifers seems to be predominately southward. However, carbonate rocks beneath the Funeral Mountains also might provide preferential conduits or drains for flow from the basin-fill sediments beneath the Amargosa Desert toward Death Valley.

Winograd and Thordarson (1975, p. 14-46) divided the area around the Nevada Test Site into six 


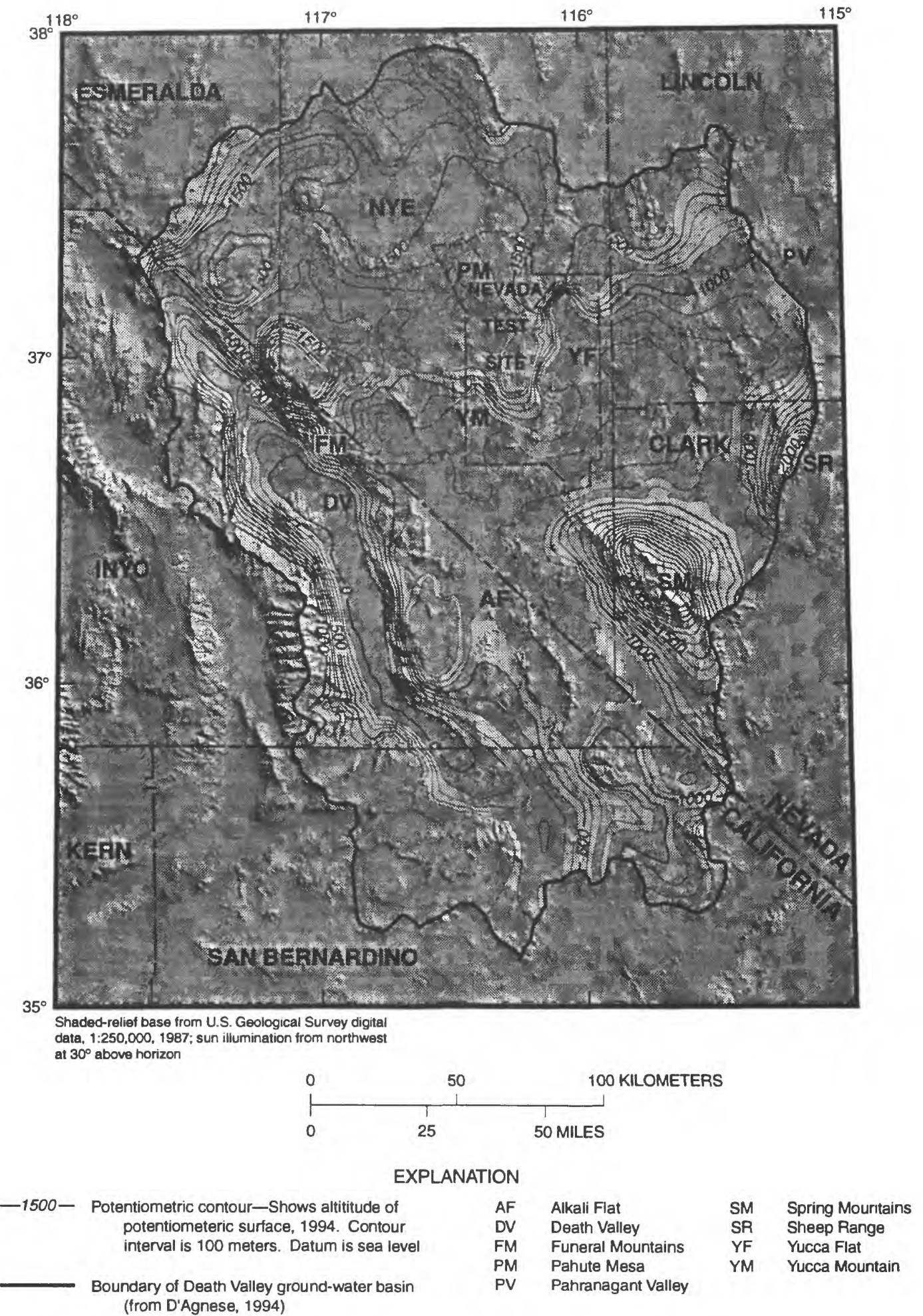

Figure 6. Potentiometric surface, Death Valley region (from D'Agnese, 1994). 
aquifers and four confining units (table 1). However, not all of these aquifers and confining units are present at or near Yucca Mountain. Only those units present near Yucca Mountain will be discussed in this section, and the nomenclature of Winograd and Thordarson (1975) will be used in this section only to be consistent with previous work. The valley fill around Yucca Mountain is above the saturated zone and thus is not an aquifer; however, it is an important aquifer south of Yucca Mountain and may be saturated in parts of Crater Flat. The lava-flow aquifer is not present at Yucca Mountain, but is present east of Yucca Mountain in well J-11 in Jackass Flats. The lower part of the welded-tuff aquifer is present at Yucca Mountain and is an important aquifer along Fortymile Wash and in Crater Flat. The bedded-tuff aquifer and lava-flow confining unit are not present at Yucca Mountain but may possibly be present in Jackass Flats. The tuff confining unit is present at Yucca Mountain, and parts of it yield substantial quantities of water to wells. In the "Hydrogeologic Units" section of this report, the tuff confining unit will be subdivided into two confin- ing units and one aquifer. The upper carbonate aquifer is not present in the Yucca Mountain region and therefore is not listed in table 1. The upper clastic confining unit is not present in any boreholes drilled at Yucca Mountain, but geophysical evidence and some conceptual models conceive of it existing deeply beneath northern Yucca Mountain (see "Large Hydraulic Gradient" section). The lower carbonate aquifer was penetrated by borehole UE- 25 p\#1 and may be present at least to the south and east of Yucca Mountain. The lower clastic confining unit would be too deeply buried to be penetrated by boreholes at Yucca Mountain.

\section{HYDROLOGY OF THE SATURATED ZONE AT YUCCA MOUNTAIN}

This section concentrates on the saturated-zone ground-water flow system in the immediate vicinity of Yucca Mountain and includes a smaller area than probably will be used for the site-scale numerical model. In this report, the site-scale hydrologic setting

Table 1. Selected regional stratigraphic and hydrogeologic units in the vicinity of Yucca Mountain (modified from Winograd and Thordarson, 1975, table 1)

[Remarks by authors of this report]

\begin{tabular}{|c|c|c|c|c|}
\hline System & Series & $\begin{array}{c}\text { Stratigraphic } \\
\text { unit }\end{array}$ & $\begin{array}{c}\text { Hydrogeologic } \\
\text { unit }\end{array}$ & Remarks \\
\hline $\begin{array}{l}\text { Quaternary and } \\
\text { Tertiary }\end{array}$ & $\begin{array}{l}\text { Holocene, } \\
\text { Pleistocene, } \\
\text { and Pliocene }\end{array}$ & Valley fill & Valley-fill aquifer & $\begin{array}{l}\text { Unsaturated near } \\
\text { Yucca Mountain }\end{array}$ \\
\hline \multirow{5}{*}{ Tertiary } & \multirow{5}{*}{ Miocene } & $\begin{array}{l}\text { Basalt of Kiwi Mesa } \\
\text { and others }\end{array}$ & Lava-flow aquifer & $\begin{array}{l}\text { Exists east of Yucca } \\
\text { Mountain in Jackass Flats }\end{array}$ \\
\hline & & $\begin{array}{l}\text { Timber Mountain } \\
\text { Group and upper } \\
\text { Paintbrush Group }\end{array}$ & Welded-tuff aquifer & $\begin{array}{l}\text { Lower part is upper volcanic } \\
\text { aquifer of this report }\end{array}$ \\
\hline & & $\begin{array}{l}\text { Lower Paintbrush } \\
\text { Group }\end{array}$ & Bedded-tuff aquifer & $\begin{array}{r}\text { Does not exist near } \\
\text { Yucca Mountain }\end{array}$ \\
\hline & & $\begin{array}{l}\text { Upper Wahmonie } \\
\text { Formation }\end{array}$ & $\begin{array}{l}\text { Lava-flow confining } \\
\text { unit }\end{array}$ & $\begin{array}{l}\text { Does not exist near } \\
\text { Yucca Mountain }\end{array}$ \\
\hline & & $\begin{array}{l}\text { Lower Wahmonie } \\
\text { Formation, Calico } \\
\text { Hills Formation, } \\
\text { Crater Flat Group, } \\
\text { and others }\end{array}$ & Tuff confining unit & $\begin{array}{l}\text { Subdivided into upper } \\
\text { confining unit and lower } \\
\text { volcanic aquifer in this } \\
\text { report }\end{array}$ \\
\hline $\begin{array}{l}\text { Mississippian to } \\
\text { Upper Devonian }\end{array}$ & & Eleana Formation & $\begin{array}{l}\text { Upper clastic confining } \\
\text { unit }\end{array}$ & $\begin{array}{l}\text { May exist beneath northern } \\
\text { Yucca Mountain }\end{array}$ \\
\hline $\begin{array}{r}\text { Devonian to } \\
\text { Cambrian }\end{array}$ & & & $\begin{array}{l}\text { Lower carbonate } \\
\text { aquifer }\end{array}$ & $\begin{array}{l}\text { Carbonate aquifer of this } \\
\text { report }\end{array}$ \\
\hline $\begin{array}{l}\text { Lower Cambrian to } \\
\text { Precambrian }\end{array}$ & & & $\begin{array}{l}\text { Lower clastic confining } \\
\text { unit }\end{array}$ & $\begin{array}{l}\text { Probably exists deep beneath } \\
\text { Yucca Mountain }\end{array}$ \\
\hline
\end{tabular}


refers to an area that extends north to about Pinnacles Ridge, east past Fortymile Wash, south to about the southern end of Yucca Mountain, and west past Solitario Canyon. These are only general boundaries for the purposes of this report and do not represent real hydrologic boundaries. When a numerical model of the site-scale flow system is developed, it need not necessarily have these same boundaries.

This section begins with a discussion of hydrogeologic units for the site-scale hydrologic setting. These hydrogeologic units will be used to organize later information. Potentiometric data (water levels) then are discussed. These data are quite abundant and reliable in the Yucca Mountain area but are sometimes difficult to interpret. Next, hydraulic data collected at various boreholes are discussed. These data are sparse and do not provide a clear picture of the site-scale setting. Concepts about inflows to and outflows from the system then are discussed. These subsections discuss only concepts because data on inflows and outflows are extremely limited. Hydrochemical data are discussed, but these data do not, in themselves, provide much information about the flow system. The section ends with a discussion of paleohydrology; that is, how the flow system may have been different in the recent geologic past.

\section{Hydrogeologic Units}

Hydrologists generally define hydrogeologic units by combining adjacent stratigraphic units that have similar hydrologic properties. This method is usually appropriate for sedimentary rocks in which the rock matrix tends to dominate hydrologic properties. For other rocks, in which secondary effects such as fracturing, tend to dominate hydrologic properties, hydrogeologic units are much more difficult to define. At Yucca Mountain, where the volcanic rocks may or may not be fractured and where the hydrologic properties can change significantly in a single stratigraphic unit, stratigraphic units are useful only in a very general sense for defining hydrogeologic units.

The Tertiary volcanic section at Yucca Mountain consists of a series of ash-flow and bedded tuffs that contain minor amounts of lava and flow breccia. Individual ash-flow tuffs may be as much as several hundred meters thick, whereas bedded tuffs generally are less than a few tens of meters thick. Ash-flow tuffs range from nonwelded to densely welded, and the degree of welding varies both areally and vertically in a single flow unit. Nonwelded ash-flow tuffs, when unaltered, have moderate to small matrix permeability, but large porosity. Permeability is greatly decreased by secondary alteration, and fractures are infrequent and often closed in the low-strength nonwelded tuffs. Consequently, these rocks constitute laterally extensive saturated-zone confining units in the Yucca Mountain area. Partly welded tuffs have properties that are between the properties represented by fractured, welded tuffs and by altered, nonwelded tuffs. The densely welded tuffs generally have minimal primary porosity and water-storage capacity, but they can be highly fractured. Where interconnected, fractures can easily transmit water and highly fractured units function as aquifers. In general, the bedded tuffs have large primary porosity and can store large amounts of water. Their matrix permeability is moderate to small, depending on the degree of alteration. The bedded tuffs generally function as confining units, at least when compared to less porous but densely fractured ash-flow tuffs. Lavas, flow breccias, and other minor rock types are neither thick nor widely distributed in the Yucca Mountain area. Their hydraulic properties are probably as variable as the properties of the ashflow tuffs, but the relatively limited areal distribution of these minor rock types makes them generally unimportant to the hydrology of Yucca Mountain.

As depth increases, even fractured tuffs and lavas may not easily transmit water because lithostatic loading keeps the fractures closed. In addition, where volcanic glass has been partly replaced by zeolites and clays, particularly in the originally vitric nonwelded tuffs, these secondary minerals substantially decrease permeability and, thus, saturated ground-water flow through the rock. The degree of alteration can greatly affect the water-transmitting characteristics of the volcanic sequence. Alteration, particularly in the Calico Hills Formation, increases to the north at Yucca Mountain (Moyer and Geslin, 1995, p. 10) and probably accounts for the apparent decrease in hydraulic conductivity to the north. Alteration also tends to increase with depth and is pervasive below the Calico Hills Formation.

To summarize the understanding of the saturated-zone flow system at Yucca Mountain, the Tertiary volcanic sequence was divided into two aquifers and two confining units (fig. 7) that seem to have generally similar hydrologic properties. These hydrogeologic units are similar to the ones proposed by 


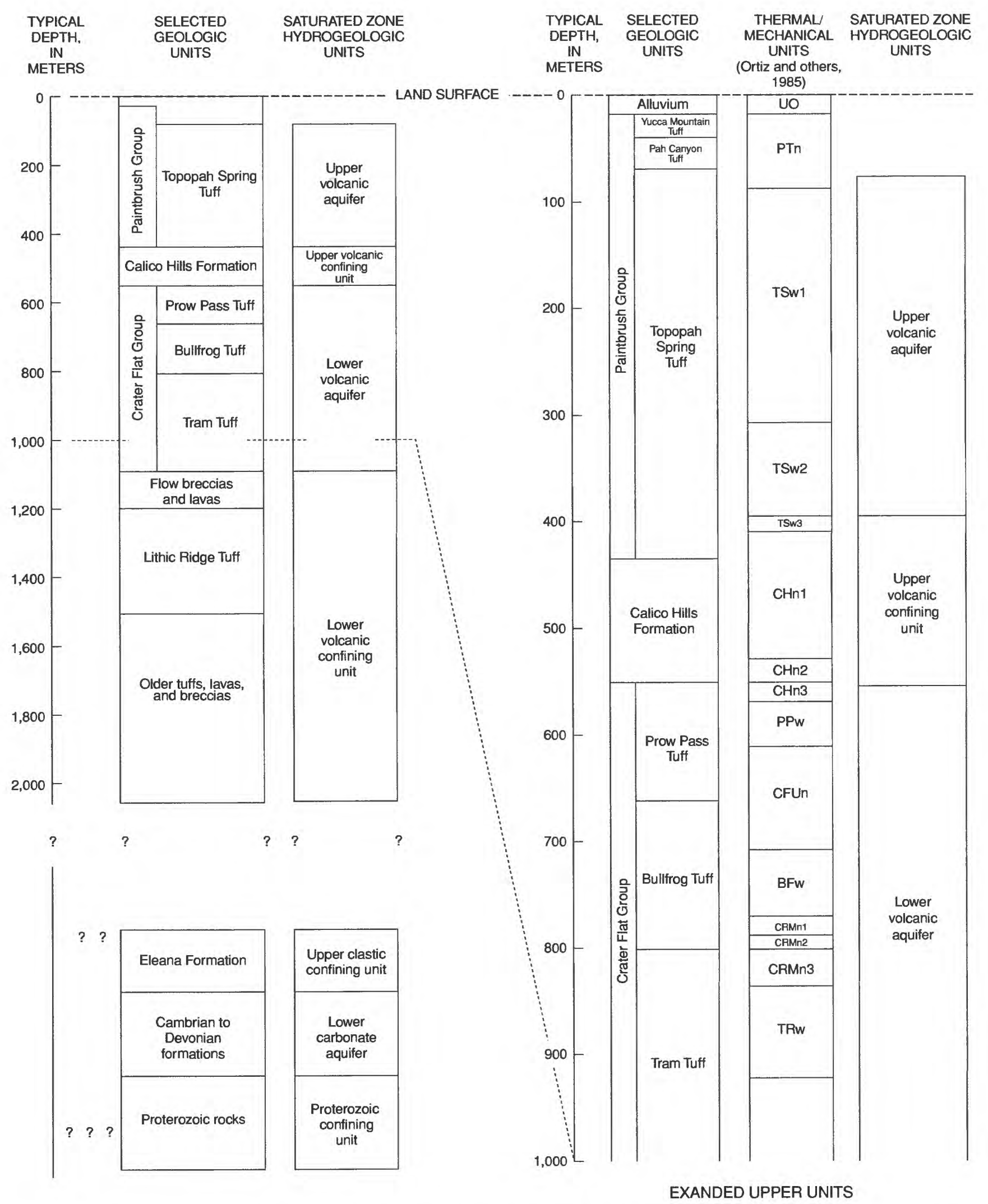

Figure 7. Selected geologic, thermal/mechanical, and hydrogeologic units at Yucca Mountain, Nevada. Only upper units shown. 
Ervin and others (1994, p. 4-5). The definition of the hydrogeologic units may change as more field data are obtained or when a numerical flow model is developed. The exact stratigraphic locations of the hydrogeologic-unit contacts are vague in this report and may change as the hydrogeologic information is reinterpreted. The altitudes for the hydrogeologic units penetrated by selected boreholes and wells at Yucca Mountain are listed in table 2. Geologic and thermal/ mechanical units along with hydrogeologic units are shown in figure 7 because both were helpful in selecting the hydrogeologic units. The division of stratigraphic and thermal/mechanical units into aquifers and confining units was based on the relative permeability of the units. In general, the units designated as aquifers seem to be more permeable than the units designated as confining units. However, locally, an aquifer may function as a confining unit or vice versa. In this report, the Paleozoic sequence is divided into the same hydrogeologic units used by Winograd and Thordarson (1975).

The upper volcanic aquifer consists of the densely welded part of the Topopah Spring Tuff of the Paintbrush Group (fig. 7). It generally corresponds to the TSw1 and TSw2 thermal/mechanical units defined by Ortiz and others (1985). It is saturated only to the east and south of Yucca Mountain and in Crater Flat.
This productive aquifer is the source of water for supply wells $\mathrm{J}-12$ and $\mathrm{J}-13$. At $\mathrm{J}-13$, about 70 percent of the unit is saturated (Thordarson, 1983). Farther north near Fortymile Wash, at boreholes UE-25 WT\#13, UE-25 WT\#14, and UE-25 WT\#15, only the lower part ( 6 to 25 percent) of the Topopah Spring Tuff is saturated. South of Yucca Mountain, only the lower part of the unit is saturated in boreholes USW WT-11 (8 percent) and UE-25 WT\#12 (15 percent). In Crater Flat, only the lower part of the Topopah Spring Tuff is saturated in borehole USW WT-10, but the Topopah Spring Tuff is fully saturated in borehole USW

VH-1. Beneath the center of Yucca Mountain, the unit is above the saturated zone.

The upper volcanic confining unit consists of the basal vitrophyre of the Topopah Spring Tuff where it is not fractured or the fractures are plugged, the bedded tuff beneath the Topopah Spring Tuff, the Calico Hills Formation, and the uppermost, nonwelded part of the Prow Pass Tuff of the Crater Flat Group (fig. 7). The upper volcanic confining unit generally corresponds to the TSw3, CHn1, and $\mathrm{CHn} 2$ thermal/ mechanical units defined by Ortiz and others (1985). This confining unit can produce water, notably from boreholes UE-25 b\#1 (Lobmeyer and others, 1983, fig. 8), UE-25 c\#3 (Geldon, 1993, fig. 33), and well J-13 (Thordarson, 1983, table 12). However,

Table 2. Altitudes of hydrogeologic units in deep boreholes at Yucca Mountain

[All altitudes are in meters above sea level; water level is for uppermost interval monitored; base of hydrogeologic unit is shown even if it is above the saturated zone; >TD indicates that at the total depth borehole was still in or had not reached this hydrogeologic unit]

\begin{tabular}{|c|c|c|c|c|c|c|}
\hline \multirow[b]{2}{*}{$\begin{array}{l}\text { Borehole } \\
\text { name }\end{array}$} & \multirow[b]{2}{*}{$\begin{array}{l}\text { Altitude of } \\
\text { water level }\end{array}$} & \multirow[b]{2}{*}{$\begin{array}{l}\text { Altitude of } \\
\text { bottom of } \\
\text { borehole }\end{array}$} & \multicolumn{4}{|c|}{ Altitude of base of hydrogeologic unit } \\
\hline & & & $\begin{array}{l}\text { Upper } \\
\text { volcanic } \\
\text { aquifer }\end{array}$ & $\begin{array}{c}\text { Upper } \\
\text { volcanic } \\
\text { confining unit }\end{array}$ & $\begin{array}{l}\text { Lower } \\
\text { volcanic } \\
\text { aquifer }\end{array}$ & $\begin{array}{c}\text { Lower } \\
\text { volcanic } \\
\text { confining unit }\end{array}$ \\
\hline USW G-1 & 750 & -503 & 933 & 777 & 252 & $>\mathrm{TD}$ \\
\hline USW G-2 & 1,020 & -277 & 1,056 & 730 & 361 & $>\mathrm{TD}$ \\
\hline USW G-3 & 730 & -53 & 1,119 & 1,005 & 307 & $>\mathrm{TD}$ \\
\hline USW G-4 & 731 & 355 & 875 & 733 & $>\mathrm{TD}$ & $>\mathrm{TD}$ \\
\hline USW H-1 & 731 & -526 & 871 & 736 & 200 & $>\mathrm{TD}$ \\
\hline USW H-3 & 731 & 264 & 1,119 & 1,030 & 387 & $>\mathrm{TD}$ \\
\hline USW H-4 & 730 & 30 & 888 & 753 & 94 & $>\mathrm{TD}$ \\
\hline USW H-5 & 776 & 259 & 996 & 886 & 439 & $>\mathrm{TD}$ \\
\hline USW H-6 & 776 & 82 & 931 & 843 & 427 & $>\mathrm{TD}$ \\
\hline UE-25 b\#1 & 731 & -19 & 806 & 631 & 12 & $>\mathrm{TD}$ \\
\hline UE-25 c\#1 & 730 & 216 & 758 & 615 & $>\mathrm{TD}$ & $>\mathrm{TD}$ \\
\hline UE-25 p\#1 & 752 & -691 & 780 & 678 & 241 & -130 \\
\hline $\mathrm{J}-13$ & 728 & -52 & 612 & 481 & 36 & $>\mathrm{TD}$ \\
\hline
\end{tabular}


production from the upper volcanic confining unit is small compared to production from either the upper or lower volcanic aquifer (see "Hydraulic Properties" section). The upper volcanic confining unit is above the saturated zone beneath much of the southern part of Yucca Mountain (Fridrich and others, 1994, fig. 5); in the remainder of the southern area, only the lower part generally is saturated. At borehole UE-25 b\#1, about 67 percent of the unit is saturated, whereas at borehole USW WT-1, only 8 percent is saturated. Almost all of the upper volcanic confining unit is in the saturated zone at borehole USW G-2 at the north end of Yucca Mountain. The confining unit thickens to the northeast, and the thickness of the zeolitic facies increases from southwest to northeast (Montazer and Wilson, 1984, p. 17; Moyer and Geslin, 1995, p. 10). To the northeast, the increases in thickness and in zeolitization of this unit probably make it more effective as a confining unit.

The lower volcanic aquifer consists of most of the Prow Pass Tuff and the underlying Bullfrog and Tram Tuffs of the Crater Flat Group (fig. 7). The uppermost part of the Prow Pass Tuff, if it is not fractured, is included with the upper volcanic confining unit. The lower volcanic aquifer underlies all of Yucca Mountain, and its units generally are completely or mostly in the saturated zone (table 2). The lower volcanic aquifer usually has a substantial number of fractures in it, but during hydraulic testing, most of the water came from only a small percentage of the fractures. The zones in this aquifer that yield water are highly variable and are difficult to predict (see "Flow Surveys" section). The lower volcanic aquifer tends to be less productive where it and the upper volcanic aquifer are present. For example, well J-13 probably obtains, at most, a small percentage of its water from this aquifer (Thordarson, 1983, table 12). Because the lower volcanic aquifer is deeper, increased lithostatic load probably accounts for part of the difference between the two aquifers, but the lower aquifer also tends to be much less densely fractured than the upper volcanic aquifer (Spengler and others, 1984, fig. 14). The lower volcanic aquifer also is more altered, which also accounts for the decreased permeability. Recent pneumatic testing of selected boreholes in the unsaturated zone confirmed that the lower volcanic aquifer is less permeable than the upper volcanic aquifer (G.D. LeCain, U.S. Geological Survey, written commun., 1994). The same testing also confirmed that the upper volcanic confining unit is less permeable than either the upper or lower volcanic aquifer.

The lower volcanic confining unit consists of bedded tuffs, lava flows, and flow breccia beneath the Tram Tuff, and includes the Lithic Ridge Tuff and older flows and tuffs beneath the Lithic Ridge Tuff (fig. 7). This hydrogeologic unit is penetrated only by the deepest boreholes at Yucca Mountain (table 2). It is present in several geologic boreholes (USW G-1, USW G-2, and USW G-3) and was tested in hydrologic borehole USW H-1 and in multipurpose borehole UE-25 p\#1. The lower volcanic confining unit also was penetrated and tested in borehole UE- $25 \mathrm{b \# 1}$ and well J-13, but the tests included part of the overlying lower volcanic aquifer. Even though some zones in the lower confining unit are fractured, the unit may be buried so deeply that the fractures are closed and do not transmit substantial quantities of water.

Beneath the Tertiary volcanic section at Yucca Mountain are Paleozoic rocks that compose the upper Paleozoic confining unit(?) and the lower Paleozoic carbonate aquifer as defined by Winograd and Thordarson (1975, p. 14-30). The upper Paleozoic carbonate aquifer as defined by Winograd and Thordarson (1975, p. $30-31)$ is not present in the Yucca Mountain area. Within this report, the lower carbonate aquifer is referred to as simply the carbonate aquifer. The upper Paleozoic confining unit (Winograd and Thordarson, 1975 , p. 43) has not been found in outcrops or boreholes at Yucca Mountain. However, Robinson (1985) in his interpretation of pre-Cenozoic geology and structure, inferred, partly on the basis of a magnetic lineation, that the altered Eleana Formation that crops out in the Calico Hills to the east also exists beneath the volcanic section under northern Yucca Mountain. Part of the carbonate aquifer is penetrated by only one borehole in the Yucca Mountain area, UE-25 p\#1. This borehole was drilled where geophysical data indicated a buried topographic high in the carbonate rocks. The carbonate aquifer exists well to the south and east of Yucca Mountain, but its presence beneath northern Yucca Mountain and in Crater Flat to the west has not been documented by drilling. If the carbonate aquifer does exist in these areas, it may be so deep that it is below the effective base of the hydrologic system.

An oil-test hole about $6 \mathrm{~km}$ south of the town of Amargosa Valley intersected the carbonate aquifer at depths from 670 to $1,524 \mathrm{~m}$ below land surface (Carr and others, 1995). The presence of the carbonate 
aquifer at this site indicates, but does not demonstrate, that the carbonate aquifer extends from eastern Yucca Mountain southward into the Armagosa Desert.

Because so little is known about the Paleozoic rocks beneath Yucca Mountain, this report does not attempt to subdivide these rocks into aquifers and confining units beyond what was done by Winograd and Thordarson (1975). In the region, where the Eleana Formation is thick, the Paleozoic rocks are generally subdivided into an upper aquifer, a confining unit, and a lower aquifer. If the Eleana Formation is thin or absent, the Paleozoic rocks are generally lumped into a single aquifer. Although the Paleozoic rocks are subdivided into an aquifer and two confining units in figure 7, in the remainder of this report, when the Paleozoic rocks are discussed, they generally are treated as forming a single carbonate aquifer. Beneath the Paleozoic rocks is the Proterozoic confining unit.

\section{Potentiometric Surface}

Robison (1984, fig. 2) constructed a preliminary potentiometric-surface map for the immediate vicinity of Yucca Mountain using primarily 1983 water-level data. Robison's (1984) map is reproduced in this report as figure 8. This map shows contours for 1,000 to $730 \mathrm{~m}$ above sea level and indicates a gradient toward the south and east in the immediate vicinity of Yucca Mountain. The contours indicate a large hydraulic gradient in the northern part of the area with a southward water-level decrease of $60 \mathrm{~m}$ per $0.5 \mathrm{~km}$ (gradient of 0.12 ) and $200 \mathrm{~m}$ in $1.5 \mathrm{~km}$ (gradient of 0.13). A moderate eastward hydraulic gradient of $20 \mathrm{~m}$ in $0.4 \mathrm{~km}$ (gradient of 0.05 ) is shown just west of the crest of Yucca Mountain in the vicinity of Solitario Canyon. Most of the area east of Solitario Canyon and south of borehole USW H-1 has a very small hydraulic gradient, as indicated by the data points. There is only a single contour $(730 \mathrm{~m})$ in this area. The 1983 data were not sufficiently accurate to compute a meaningful hydraulic gradient in the small-gradient area.

Ervin and others $(1993,1994)$ revised the potentiometric-surface map in the area of the small hydraulic gradient (fig. 9). The large and moderate hydraulic gradients were identified and discussed, but were not contoured because no new data were available to update the previous (Robison, 1984) map. Ervin and others' $(1993,1994)$ map (fig. 9) used primarily mean 1988 water-level data. These data were more accurate than data that were available to earlier investigators because of improvements in measuring techniques (Boucher, 1994b). The map, which has a contour interval of $0.25 \mathrm{~m}$, indicates a range of waterlevel altitudes from about $731.0 \mathrm{~m}$ beneath the crest of Yucca Mountain to about $728.5 \mathrm{~m}$ near Fortymile Wash. The predominant direction of the ground-water gradient shown in figure 9 is to the east-southeast.

\section{Large Hydraulic Gradient}

The potentiometric surface at the north end of Yucca Mountain is characterized by a large hydraulic gradient (contoured at 0.13 and possibly as large as 0.15 ) between altitudes of approximately 1,030 to $750 \mathrm{~m}$; the surface is markedly steeper than the surface toward the south and east (fig. 8). Although relatively large hydraulic gradients have been observed in southern Nevada (Winograd and Thordarson, 1975, figs. 32, 33, and pl. 2; Waddell and others, 1984, pl. 2), these large gradients generally were associated with known geologic or topographic features, such as edges of thick confining units, faults with major offset, caldera boundaries, or mountain range fronts. The large hydraulic gradient at the north end of Yucca Mountain is unique only in its lack of obvious geologic cause. However, the lack of an obvious geologic cause may be more a function of the scarcity of data than an inherent feature of this large hydraulic gradient.

Several hypotheses have been advanced to explain the large hydraulic gradient. One hypothesis is that the large hydraulic gradient is simply the result of flow through the upper volcanic confining unit. The 1994 water-level altitude in borehole USW G-2 at the northern end of the large hydraulic gradient was $1,020 \mathrm{~m}$ (table 2) and is in the upper volcanic confining unit. The base of the upper volcanic confining unit is at an altitude of about $730 \mathrm{~m}$ (table 2), so the saturated thickness of the confining unit is almost $300 \mathrm{~m}$. A large hydraulic gradient could be expected in a thick confining unit. Because the unit that composes the upper volcanic confining unit is not saturated to its full thickness at borehole USW G-2, the large hydraulic gradient may persist somewhat north to the area where the potentiometric surface is in the upper volcanic aquifer. The lower volcanic aquifer in this area also could have decreased hydraulic conductivity because of lithostatic pressure and hydrothermal alteration, which also would contribute to the large hydraulic gradient. 


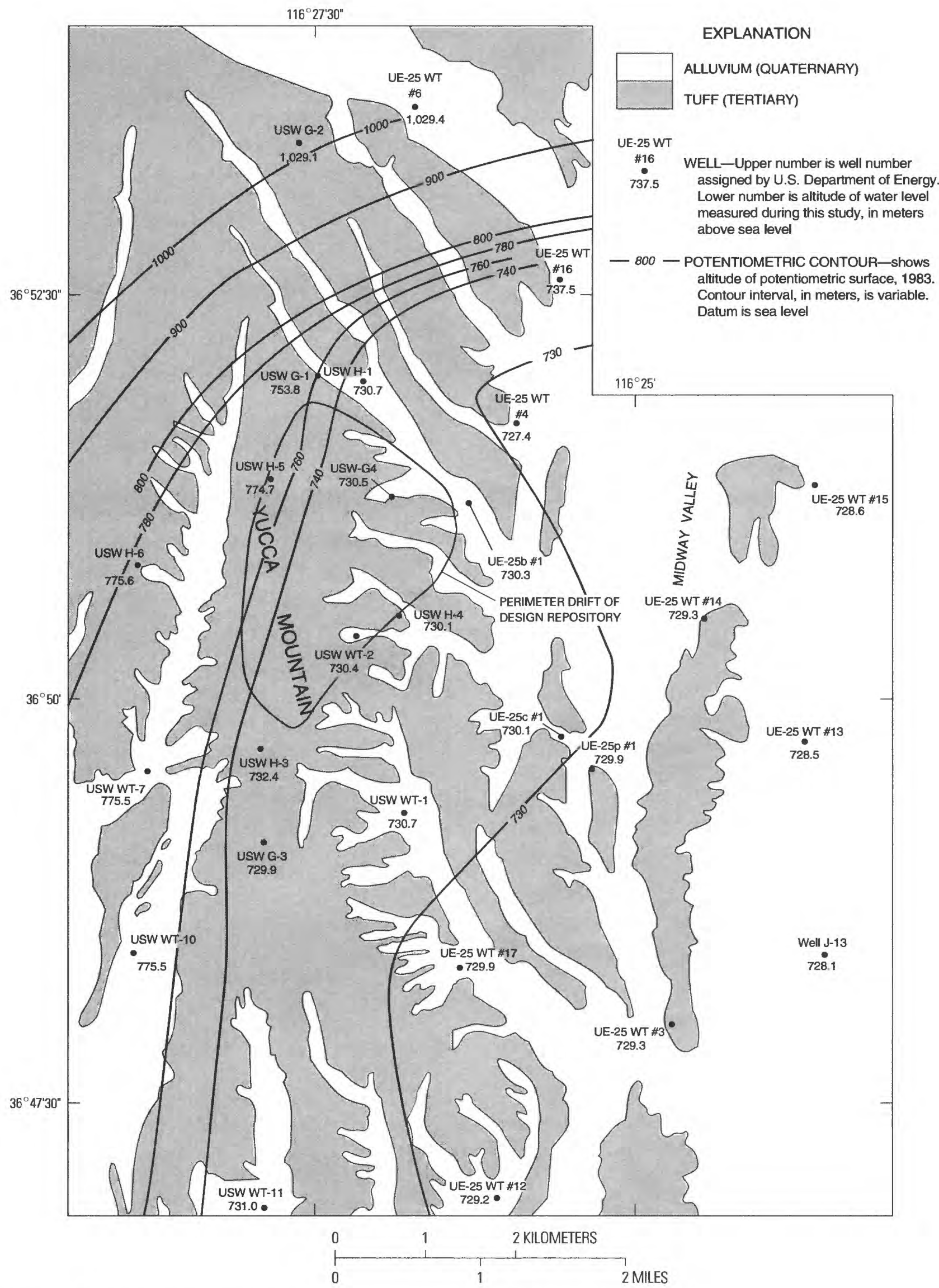

Figure 8. Preliminary potentiometric surface, Yucca Mountain (from Robison, 1984, fig. 2). 


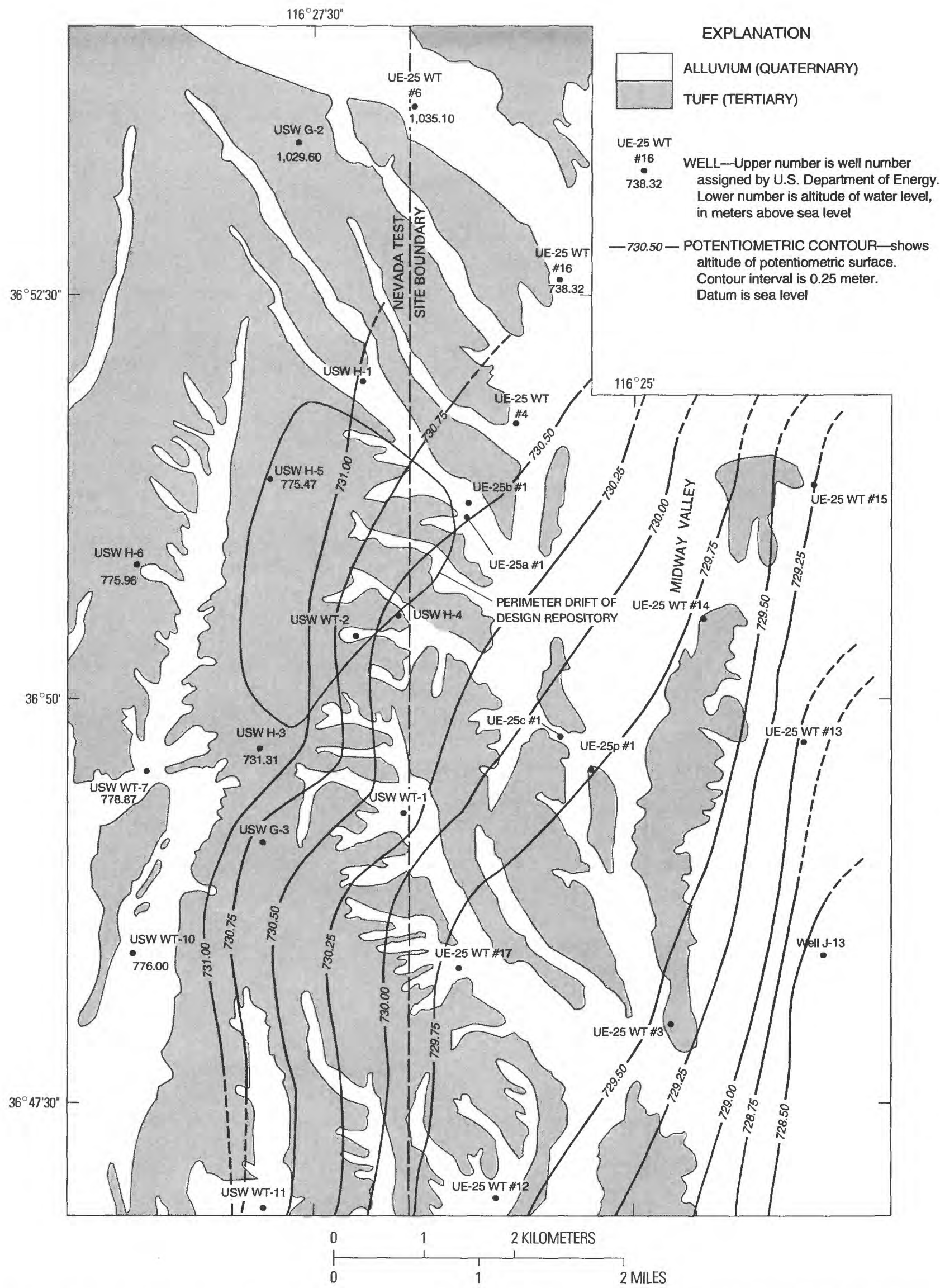

Figure 9. Revised potentiometric surface of an area of small hydraulic gradient, Yucca Mountain (from Ervin and others, 1993, fig. 1). 
Ervin and others (1994, p. 9-11) advanced the hypothesis that the large hydraulic gradient represents a semiperched system (Meinzer, 1923, p. 41). In a semiperched system, flow in the upper and lower aquifers would be predominantly horizontal, whereas flow in the confining unit would be predominantly vertical. Winograd and Thordarson (1975, p. 50) reported that semiperched water is not uncommon at and in the vicinity of the Nevada Test Site. The water levels to the north of the large hydraulic gradient represent levels in the upper volcanic aquifer, whereas water levels to the south represent levels in the lower volcanic aquifer (table 2). The upper volcanic confining unit separates these two systems. Under this hypothesis, the large hydraulic gradient may simply be an artifact of attempting to contour points from two different and widely separated surfaces. Water levels from boreholes completed in the confining unit between these two different surfaces (such as UE-25 WT\#6), where flow is essentially vertical and water levels change dramatically with depth, would be difficult to interpret. To the north of the large hydraulic gradient, flow in the upper volcanic aquifer probably is limited with most of the water being lost to downward seepage into the lower volcanic aquifer. What little water remains in the upper volcanic aquifer at the north end of the large hydraulic gradient probably is lost in a short distance as it moves vertically through the upper volcanic confining unit and ultimately reaches the lower volcanic aquifer (Ervin and others, 1994, p. 9-11). The permeability of the lower volcanic aquifer at the north end of Yucca Mountain may be extremely limited due to lithostatic loading and to alteration. Water in the upper volcanic aquifer also may be diverted around the large hydraulic gradient into Crater Flat or along Fortymile Wash. In this hypothesis (Ervin and others, 1994, p. 9-11), the hydraulic gradient in the lower volcanic aquifer probably increase to the north as hydraulic conductivity decreases, but does not increase as dramatically as shown on the potentiometric-surface map (fig. 8). Borehole USW G-2 in this area produced little, if any, water from the lower volcanic aquifer (see "Flow Surveys" section).

Fridrich and others $(1991,1994)$ proposed the hypothesis that the large hydraulic gradient represents a drain and is part of a regional large hydraulic gradient that extends many kilometers to the northeast of Yucca Mountain. They argued, based on gravity and stratigraphic indicators, that a fault in the vicinity of the large hydraulic gradient is buried beneath the
Calico Hills Formation and is the northern-bounding fault of a buried graben. There is no surface expression of the postulated fault. In this hypothesis, Fridrich and others (1994) suggested that this fault marks the northern extent of active flow in the carbonate aquifer and provides a drain that moves water from the volcanic aquifers into the carbonate aquifer. The drain removes most of the water from the volcanic aquifers and greatly decreases flow through the volcanic aquifers to the south, which accounts for the small hydraulic gradient to the south and east of Yucca Mountain. Part of the water returns to the lower volcanic aquifer south of the large hydraulic gradient through faults, most notably the Solitario Canyon, Bow Ridge, and Paintbrush Canyon faults (fig. 3). This hypothesis is intriguing in that it also accounts for the anomalously low heat flow observed at Yucca Mountain (Sass and others, 1988), but the hypothesis must rely heavily on aeromagnetic and gravity data to define the buried graben because other geologic data are sparse.

Fridrich and others (1994) proposed a second hypothesis, the spillway hypothesis, to explain the large hydraulic gradient. This explanation requires the same deeply buried fault; but, in this spillway hypothesis, the fault marks the effective northern limit of the lower volcanic aquifer. Fridrich and others (1994) speculated that, as a result of the fault, the Crater Flat Group is thinner to the north of the graben, is more altered, and is much less permeable than it is to the south. This explanation envisions very little flow from the north, and what little flow there is drops abruptly at the northern-bounding fault of the buried graben.

Another hypothesis is that the large hydraulic gradient is the result of the presence, at depth, of the Eleana Formation, which is part of the Paleozoic upper clastic confining unit described by Winograd and Thordarson (1975, p. 43). This possibility may have been considered when the large hydraulic gradient was discovered in 1981 with the drilling of borehole USW G-2 but has not been previously discussed in detail in publications although Fridrich and others $(1994$, p. 150) noted the regional large hydraulic gradient appeared to follow the contact between the upper clastic confining unit and the carbonate aquifer. The Eleana Formation is responsible for a large hydraulic gradient on the west side of Yucca Flat in the northeastern part of the Nevada Test Site (Winograd and Thordarson, 1975, p. 66). The Eleana Formation could be deeply buried beneath northern Yucca 
Mountain and could be affecting the flow system in that area in the same way it affects the flow system on the west side of Yucca Flat. No borehole has penetrated deeply enough to verify the existence or absence of the Eleana Formation to the north of Yucca Mountain. More than $5 \mathrm{~km}$ south of the large hydraulic gradient, the Eleana Formation is not present in borehole UE-25 p\#1, which penetrates the pre-Cenozoic section in carbonates of Silurian age beneath a fault contact (Carr, M.D., and others, 1986). However, the Eleana Formation is present as an altered, strongly magnetic argillite in the Calico Hills, about $15 \mathrm{~km}$ east of Yucca Mountain. Bath and Jahren (1984) attributed a prominent magnetic high to this argillite and suggested that the westward extension of the magnetic high beneath northern Yucca Mountain also indicated the presence of the Eleana Formation. Robinson (1985, fig. 9) projected the approximate location of the southern extent of the superposition of the confining unit on the carbonate aquifer, a location that correlates with the general locality of the large hydraulic gradient. The absence of the Paleozoic upper clastic confining unit south of the large hydraulic gradient could provide ground-water access to the carbonate aquifer, but the overlying lower volcanic confining unit also could prevent this access.

\section{Moderate Hydraulic Gradient}

The moderate hydraulic gradient is defined by boreholes with the altitudes of the potentiometric surface ranging from about $732 \mathrm{~m}$ to about 775 to $780 \mathrm{~m}$ (fig. 8) and is west of the crest of Yucca Mountain (Robison, 1984, fig. 2; Ervin and others, 1994, p. 8-9). Boreholes USW H-6, USW WT-7, and USW WT-10 (water-level altitudes of about $776 \mathrm{~m}$ ) (figs. 9 and 10) are located on the west side of the Solitario Canyon Fault. Borehole USW H-5 (water-level altitude of about $775 \mathrm{~m}$ ) (figs. 8 and 9) is located to the east of the Solitario Canyon Fault but on the downthrown (west) side of a major northeast-trending splay of the Solitario Canyon Fault. Boreholes USW H-1 and USW H-3 (water-level altitude about $731 \mathrm{~m}$ ) (figs. 8 and 9) are located on the east side of the Solitario Canyon Fault. The Solitario Canyon Fault is a major north-striking scissors fault, which to the south is downthrown on its western side and to the north is downthrown on the eastern side (Scott and Bonk, 1984). The hinge line of the fault, where the displacement changes, is perpendicular to the fault plane and is located approximately $1 \mathrm{~km}$ southwest of borehole USW G-2. Offset on the fault may be as much as $250 \mathrm{~m}$ (U.S. Geological Survey, 1984, p. 50). Toward its southern end, the Solitario Canyon Fault seems to widen and have more splays. Fault gouge and secondary siliceous infillings are present along the fault (M.P. Chornack, U.S. Geological Survey, oral commun., 1992). Samples of this material indicate a low matrix porosity (A.L. Flint, U.S. Geological Survey, written commun., 1992). Although fault gouge and siliceous infillings are surface features, they indicate that the fault, in the saturated zone, could have less permeability than the surrounding rock.

The Solitario Canyon Fault seems to function as a barrier to flow from west to east. Boreholes west of the fault have higher water levels than boreholes east of the fault, except for borehole USW H-5. However, borehole USW H-5 may be connected hydraulically with the boreholes west of the Solitario Canyon Fault (Ervin and others, 1994, p. 9). According to Bentley and others (1983, p. 20) and Robison and Craig (1991, p. 12-13), much of the flow in borehole USW H-5 originates from the part of the Bullfrog Tuff located at an altitude of between 720 to $780 \mathrm{~m}$ (see "Flow Surveys" section). Thus, most of the flow to the borehole comes from an interval that is above the interval where the fault splay probably intersects the borehole. The fault splay may be less permeable as a result of fault gouge. This low-permeability interval may tend to mound water against the fault splay.

The Solitario Canyon Fault could also function as a barrier because of offset of stratigraphic units, which places more permeable units against less permeable units, especially to the south where offset in the fault is greater (Ervin and others, 1994, p. 9). Some flow undoubtedly crosses the Solitario Canyon Fault because there is a large difference of hydraulic potential ( $45 \mathrm{~m}$ ) across it. However, most of the ground water west of the Solitario Canyon Fault probably flows south, either along the fault or through an aquifer in Crater Flat. A test to determine the hydrologic significance of the fault at one locality has been described by the U.S. Department of Energy (1990a, sec. 3.1).

The moderate hydraulic gradient could be interpreted as a southward extension of the large hydraulic gradient, with or without the Solitario Canyon Fault causing the moderate gradient. This extension of the large gradient could be implied by information presented by Robison (1984, fig. 2) and Fridrich and 


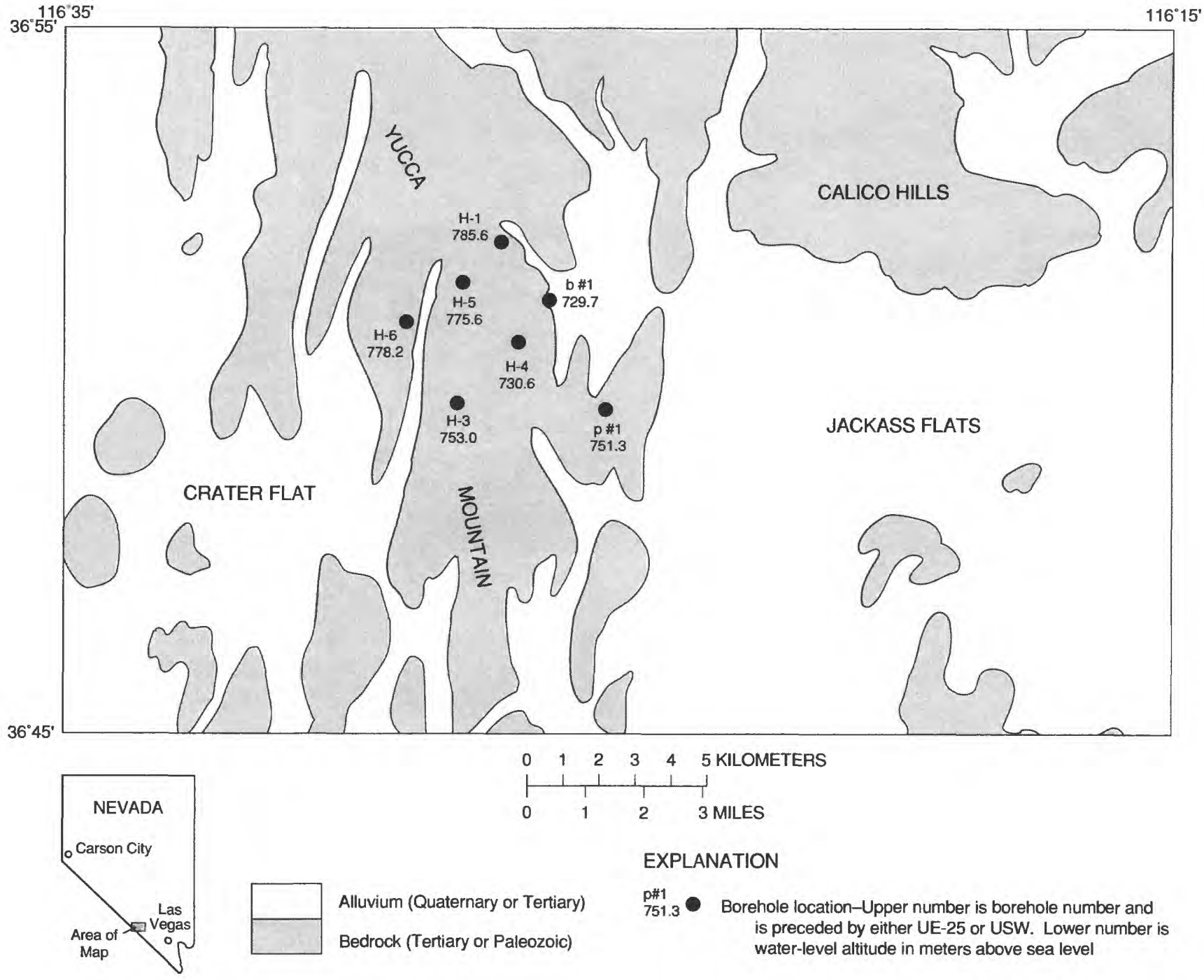

Figure 10. Potentiometric levels in the lower volcanic confining unit and carbonate aquifer.

others (1994, fig. 3). As was discussed in the "Large Hydraulic Gradient" section, Fridrich and others (1994) suggested that there could be substantial upwelling of water from the carbonate aquifer along the Solitario Canyon Fault, as well as along other north-striking faults. If such upwelling along the Solitario Canyon Fault is larger compared to along other faults, or if the hydraulic conductivity east of the Solitario Canyon Fault is less than elsewhere around Yucca Mountain, the upwelling could cause the moderate hydraulic gradient. However, if upwelling is the cause of the moderate gradient, the Solitario Canyon Fault seems to be unique in this respect because simi- lar gradients are not observed across other northstriking faults in the Yucca Mountain area.

\section{Small Hydraulic Gradient}

The small hydraulic gradient is present beneath much of eastern and southern Yucca Mountain where water levels ranged from 728 to $732 \mathrm{~m}$ above sea level (fig. 9); this area includes most of the boreholes at Yucca Mountain. The small hydraulic gradient is bounded on the north by boreholes USW H-1 and UE-25 WT\#14 (fig. 9) and on the west by boreholes USW H-1, USW H-3, USW G-4 and USW WT-11. The small hydraulic gradient extends east as far as Fortymile Wash where the water-level altitude is about 
$728 \mathrm{~m}$ and probably extends well into Jackass Flats where the water-level altitude at well J-11 was about $732 \mathrm{~m}$ (Boucher, 1994a; LaCamera and Westenburg, 1994). The southern extent of the small hydraulic gradient includes boreholes USW WT-11 and UE-25 WT\#12, but the small hydraulic gradient may extend still farther to the south. The small hydraulic gradient represents a water-level change of 0.1 to $0.3 \mathrm{~m} / \mathrm{km}$ (gradient of 0.0001 to 0.0003 ). Ervin and others (1993, p. 1558) stated that the small hydraulic gradient could indicate highly transmissive rocks, limited ground-water flow through the system, or a combination of both phenomena. The actual cause cannot be determined until further data are available.

The potentiometric surface in the area of the small hydraulic gradient slopes generally eastward from Yucca Mountain toward Fortymile Wash; a smaller component slopes to the south. Limited data east of Fortymile Wash (Waddell, 1982; Boucher, 1994a; LaCamera and Westenburg, 1994) indicated that the potentiometric surface in Jackass Flats also is relatively flat and probably slopes westward toward Fortymile Wash; again, a smaller component slopes to the south.

\section{Vertical Hydraulic Gradients}

Potentiometric levels have been measured at multiple depth intervals at 10 sites in the vicinity of Yucca Mountain (table 3). Differences in potentiometric levels at different depth intervals in the same

Table 3. Potentiometric levels at selected depth intervals in boreholes at Yucca Mountain

[Depth interval in meters; Pot. level, potentiometric level in meters above sea level]

\begin{tabular}{|c|c|c|c|c|}
\hline $\begin{array}{c}\text { Borehole } \\
\text { name }\end{array}$ & $\begin{array}{c}\text { Depth } \\
\text { Interval }\end{array}$ & Primary hydrogeologic unit & $\begin{array}{l}\text { Pot. } \\
\text { level }\end{array}$ & Remarks \\
\hline \multirow[t]{2}{*}{ UE-25 b\#1 } & $488-1,199$ & Lower volcanic aquifer & 730.71 & 1991 mean level \\
\hline & $1,199-1,220$ & Lower volcanic confining unit & 729.69 & 1991 mean level \\
\hline \multirow[t]{2}{*}{ UE-25 c\#3 } & $692-753$ & Lower volcanic aquifer & 730.22 & 1990 mean level \\
\hline & $753-914$ & Lower volcanic aquifer & 730.64 & 1990 mean level \\
\hline \multirow[t]{2}{*}{ UE-25 p\#1 } & $384-500$ & Lower volcanic aquifer & 729.90 & Craig and Robison (1984) \\
\hline & $1,297-1,805$ & Carbonate aquifer & 751.26 & Average value; Craig and Robison (1984) \\
\hline \multirow[t]{2}{*}{ USW G-4 } & $615-747$ & Lower volcanic aquifer & 730.3 & Average value; Bentley (1984) \\
\hline & $747-915$ & Lower volcanic aquifer & 729.8 & Average value; Bentley (1984) \\
\hline \multirow[t]{4}{*}{ USW H-1 } & $573-673$ & Lower volcanic aquifer & 730.94 & 1991 mean level \\
\hline & $716-765$ & Lower volcanic aquifer & 730.75 & 1991 mean level \\
\hline & $1,097-1,123$ & Lower volcanic aquifer & 736.06 & 1991 mean level \\
\hline & $1,783-1,814$ & Lower volcanic confining unit & 785.58 & 1991 mean level \\
\hline \multirow[t]{2}{*}{ USW H-3 } & $762-1,114$ & Lower volcanic aquifer & 731.35 & 1991 mean level \\
\hline & $1,114-1,219$ & Lower volcanic confining unit & 753.05 & ${ }^{1}$ Mean for $12 / 91$ \\
\hline \multirow[t]{2}{*}{ USW H-4 } & $525-1,188$ & Lower volcanic aquifer & 730.41 & 1991 mean level \\
\hline & $1,188-1,219$ & Lower volcanic confining unit & 730.56 & 1991 mean level \\
\hline \multirow[t]{2}{*}{ USW H-5 } & $708-1,091$ & Lower volcanic aquifer & 775.43 & 1991 mean level \\
\hline & $1,091-1,219$ & Lower volcanic confining unit & 775.65 & 1991 mean level \\
\hline \multirow[t]{4}{*}{ USW H-6 } & $533-752$ & Lower volcanic aquifer & 775.99 & 1991 mean level \\
\hline & $752-1,220$ & Lower volcanic aquifer & 775.91 & 1991 mean level \\
\hline & $533-1,193$ & Lower volcanic aquifer & 776.09 & Jan. - May 1984 mean level \\
\hline & $1,193-1,220$ & Lower volcanic confining unit & 778.18 & Jan. - May 1984 mean level \\
\hline \multirow[t]{4}{*}{$\mathrm{J}-13$} & $282-451$ & Upper volcanic aquifer & 728.8 & Thordarson (1983) \\
\hline & $471-502$ & Upper volcanic confining unit & 728.9 & Thordarson (1983) \\
\hline & $585-646$ & Lower volcanic aquifer & 728.9 & Thordarson (1983) \\
\hline & $820-1,063$ & Lower volcanic aquifer & 728.0 & Thordarson (1983) \\
\hline
\end{tabular}

\footnotetext{
${ }^{1}$ Potentiometric levels rising throughout 1991 in response to reconfiguration of the packer that isolates the lower interval.
} 
borehole ranged from about zero to nearly $55 \mathrm{~m}$ (table 3).

Potentiometric levels generally were higher in the lower intervals of the volcanic rocks than in the upper intervals, indicating a potential for upward ground-water movement. However, at four boreholes (USW G-4, USW H-1, USW H-6, and UE-25 b\#1), potentiometric levels in the volcanic rocks were higher in the uppermost intervals than in the next lower intervals (table 3). At borehole USW G-4, there was a downward hydraulic gradient with a potentiometric difference of $0.5 \mathrm{~m}$ between the upper and lower intervals. Both intervals are in the lower volcanic aquifer. At borehole USW H-1, the potentiometric level was about $\mathbf{0 . 2} \mathrm{m}$ higher in the uppermost interval than in the next lower interval. The potentiometric level in the third interval in borehole USW H-1 was about $5 \mathrm{~m}$ higher than that in the uppermost interval. The upper three intervals are all in the lower volcanic aquifer. The potentiometric level in the lowermost interval of borehole USW H-1, completed in the lower volcanic confining unit, was nearly $55 \mathrm{~m}$ higher than in the uppermost interval. At borehole USW H-6, there was a downward gradient with a potentiometric difference of about $0.1 \mathrm{~m}$ between the intervals that were isolated in the lower volcanic aquifer. However, based on data from 1984 (Robison and others, 1988, p. 122-123), there seemed to be an upward potentiometric difference of about $2 \mathrm{~m}$ between the lower volcanic confining unit and the lower volcanic aquifer in borehole USW H-6. At borehole UE-25 b\#1, there was a downward potentiometric difference of about $1 \mathrm{~m}$ between the lower volcanic aquifer and the lower volcanic confining unit.

Potentiometric levels in the Paleozoic carbonate aquifer at borehole UE-25 p\#1 are about $21 \mathrm{~m}$ higher than levels in the lower volcanic aquifer (Craig and Johnson, 1984, p. 12) (table 3). A potential for upward ground-water movement from the Paleozoic rocks to the volcanic rocks was, therefore, indicated. Because of the large difference in potentiometric levels in these two aquifers, they seem to be hydraulically separate. However, analyses of hydraulic-test data at the $\mathrm{C}$-hole complex ${ }^{3}$ indicated a possible hydraulic connection between the lower volcanic aquifer and the

\footnotetext{
${ }^{3}$ The C-hole complex refers to three boreholes, UE-25 c\#1, UE-25 c\#2, and UE-25 c\#3, drilled in a triangular pattern and used to conduct cross-hole hydraulic and tracer tests. See "Local Hydrologic Setting" section.
}

carbonate aquifer at the C-hole complex (Geldon, 1996). During the March 1984 test of borehole UE-25 c\#2, the water level in borehole UE-25 p\#1 apparently declined; Geldon (1996) attributed this decline to a connection between the lower volcanic aquifer and the carbonate aquifer. However, waterlevel monitoring instruments at that time may not have been reliable, and any conclusions from data collected would be tenuous. Testing at the $\mathrm{C}$-hole complex in 1995 and 1996 did not result in any water-level decline in borehole UE-25 p\#1 (A.L. Geldon, U.S. Geological Survey, written commun., 1996). Further testing at the C-hole complex (U.S. Department of Energy, 1990a, sec. 3.4) using more reliable waterlevel monitoring instruments may help to resolve the question of hydraulic connection between the lower volcanic aquifer and the carbonate aquifer at this site.

Measurement of potentiometric levels at various depth intervals in borehole UE-25 p\#1 shortly after the borehole was drilled indicated that:

1. Potentiometric levels gradually increased from $729.9 \mathrm{~m}$ to $734.5 \mathrm{~m}$ above sea level between the water table (depth of about $384 \mathrm{~m}$ ) and deep within the lower volcanic confining unit, $1,114 \mathrm{~m}$ below land surface;

2. Potentiometric levels abruptly increased to about $752 \mathrm{~m}$ above sea level in the "older tuffs" between depths of 1,110 and $1,180 \mathrm{~m}$ below land surface; and

3. Potentiometric levels remained at about $751 \mathrm{~m}$ above sea level throughout the Paleozoic carbonate aquifer to a total depth of $1,805 \mathrm{~m}$ (Craig and Robison, 1984, p. 6-9).

The lowermost $70 \mathrm{~m}$ of the older tuffs of the lower volcanic confining unit in the borehole had potentiometric levels that were very similar to the levels in the carbonate aquifer, indicating that the lowermost part of the lower volcanic confining unit and the carbonate aquifer were hydraulically connected. Such a connection could be expected in the hanging-wall rocks adjacent to a fault, and such a connection is supported by calcification of the basal tuffs in the borehole (Carr, M.D., and others, 1986, p. 23-25). The remaining $237 \mathrm{~m}$ of the lower volcanic confining unit had a potentiometric level similar to that of the lower volcanic aquifer (Craig and Robison, 1984, table 2).

No unambiguous areal patterns in the distribution of vertical hydraulic gradients around Yucca Mountain are apparent; however, some generalizations can be made as to the distribution of potentiometric 
levels in the lower sections of the volcanic rocks. Potentiometric levels in the lower volcanic confining unit are relatively high (altitude greater than $750 \mathrm{~m}$ ) in the western and northern parts of Yucca Mountain (fig. 10) and are relatively low (altitude about $730 \mathrm{~m}$ ) in the eastern part of Yucca Mountain. Based on potentiometric levels that were measured in borehole UE-25 p\#1, the potentiometric levels in the lower volcanic confining unit in boreholes USW H-1, USW H-3, USW H-5, and USW H-6 may reflect the potentiometric level in the carbonate aquifer. Boreholes UE-25 b\#1 and USW H-4 do not seem to fit the pattern established by the other boreholes (fig. 10). These two boreholes penetrated only 31 and $64 \mathrm{~m}$ respectively into the lower volcanic confining unit and had potentiometric levels (about $730 \mathrm{~m}$ ), which were similar to potentiometric levels in the lower volcanic aquifer. Penetration of the other four boreholes into the lower volcanic confining unit ranged from $123 \mathrm{~m}$ at USW H-3 to $726 \mathrm{~m}$ at USW H-1 (table 2). Perhaps only in boreholes USW H-1, USW H-3, USW H-5 and USW H-6 are the potentiometric levels in the lower volcanic confining unit influenced by the potentiometric level in the carbonate aquifer.

Vertical hydraulic gradients could have an important impact on the analysis of the effectiveness of the saturated zone as a barrier to radionuclide transport. Based on a very limited data set (five boreholes), an areally extensive upward gradient can be inferred between the carbonate aquifer and the volcanic aquifers, which may indicate that, at least for the immediate Yucca Mountain area, radionuclide transport would be restricted to the volcanic system.

\section{Potentiometric-Level Fluctuations and Trends}

Potentiometric levels have been measured since 1983 at Yucca Mountain at various frequencies ranging from occasional to continuous. The network of monitoring boreholes (fig. 11) has evolved to one that, as of the end of 1994, consisted of 15 boreholes in which 16 zones were monitored on a monthly basis, and of 12 boreholes in which 12 zones were monitored on an hourly basis and 4 zones were monitored on a continuous basis. Borehole USW H-1 has 2 zones that were monitored monthly and 2 zones that were monitored hourly. The four zones in boreholes USW H-5 and USW H-6 were equipped to continuously monitor water levels and record extremely short-term waterlevel and fluid-pressure changes in response to phenomena such as earthquakes and underground nuclear explosions (O’Brien, 1992, 1993).

Potentiometric levels in boreholes at Yucca Mountain seem to be stable with time (Ervin and others, 1994, p. 11-13). After the potentiometric levels have equilibrated following drilling or reconfiguration of packers, they generally change very little with time. Annual fluctuations are on the order of a few tenths of a meter, primarily in response to barometric changes and earth tides (fig. 12). Potentiometric levels tend to fluctuate more on a day-to-day basis during the winter in response to the larger barometric fluctuations associated with winter-storm fronts.

Examples of long-term potentiometric-level fluctuations and trends are shown in figure 12. Potentiometric levels for borehole USW WT-2 (fig. 12) are representative of potentiometric-level fluctuations in the upper part of the lower volcanic aquifer. Daily mean potentiometric levels from 1986 through 1992 ranged from about 730.5 to about $731.0 \mathrm{~m}$ above sea level and averaged about $730.7 \mathrm{~m}$. Potentiometric levels for borehole UE-25 p\#1 (fig. 12) represented potentiometric levels in the Paleozoic carbonate aquifer. Potentiometric levels were relatively stable at about $752 \mathrm{~m}$ above sea level prior to 1985 (Robison and others, 1988); however, potentiometric levels rose from about 751.8 to $752.6 \mathrm{~m}$ between 1985 and 1987 (fig. 12) and averaged about $752.5 \mathrm{~m}$ from 1987 through June 1992. The abrupt decline in potentiometric levels on June 28-29, 1992, and the subsequent rise in potentiometric levels, was in response to earthquake activity and has been discussed by $\mathrm{O}^{\prime}$ Brien (1993, p. 10).

Lehman and others (1990) examined potentiometric-level fluctuations around Yucca Mountain for 1983-88 and fit cosine functions to the data. They found periodic components of 2- to 3-year duration in nine records. They reported that potentiometric levels in boreholes east of Yucca Mountain had a similar period and it was different from the period in boreholes west of Yucca Mountain. Lehman and others (1990) believed the periodic behavior of potentiometric fluctuation was related to periodicity in precipitation. Lehman and Brown (L. Lehman and Assoc., written commun., 1994) later extended their analysis to include structural controls on ground-water flow.

Short-term fluctuations in potentiometric levels in response to earthquakes are known to occur at 


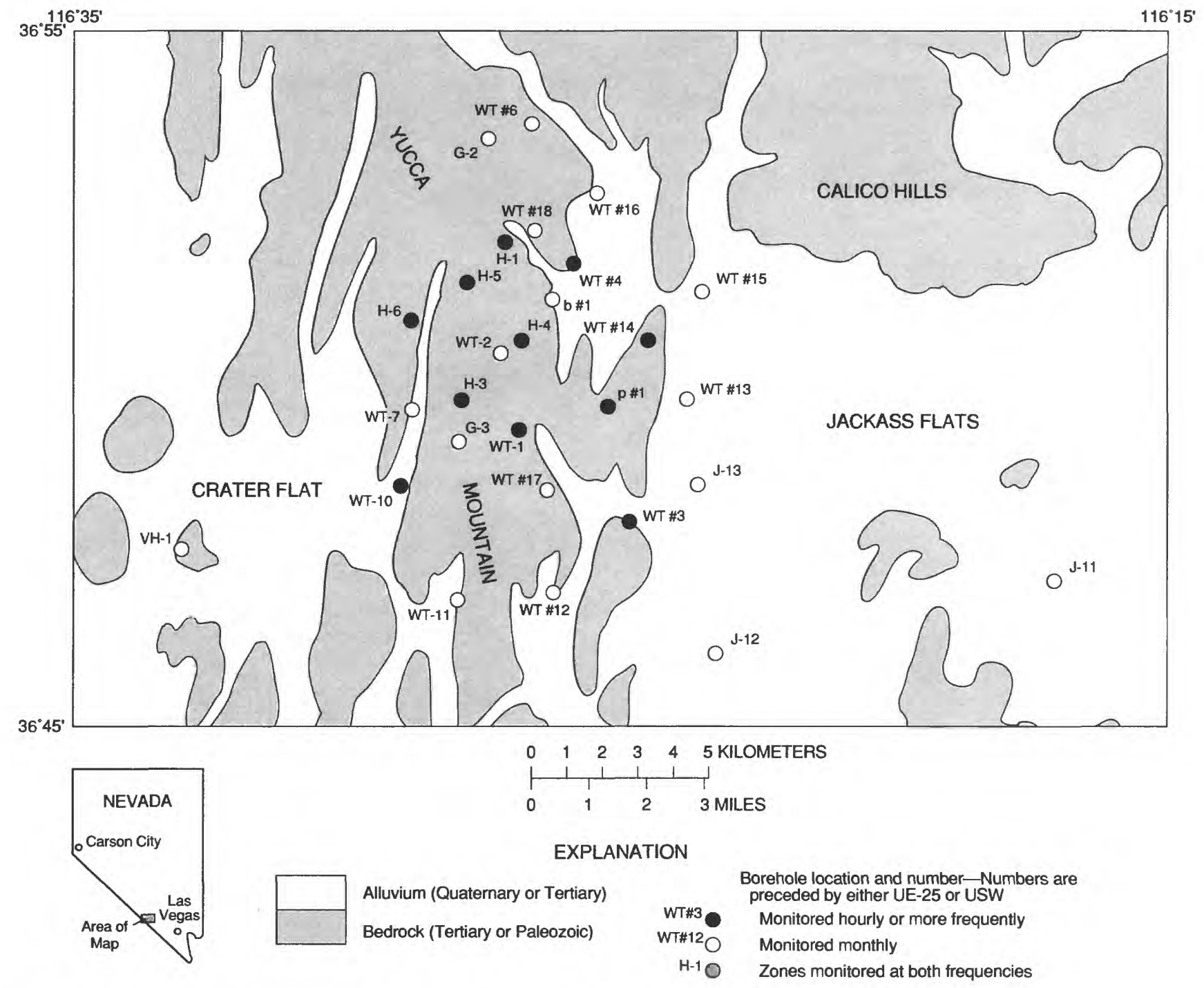

Figure 11. Locations of boreholes in the vicinity of Yucca Mountain in which water levels are monitored. 


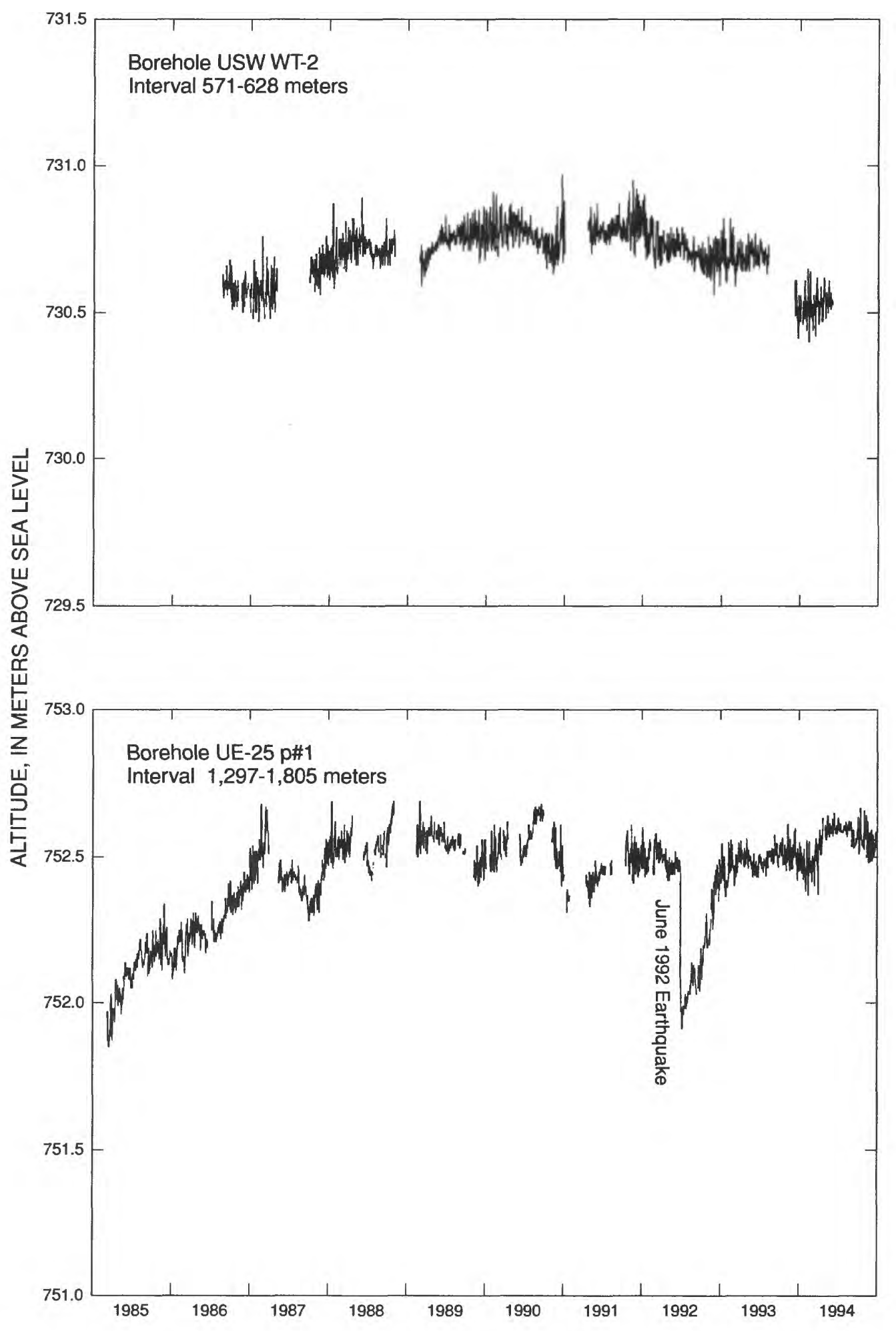

Figure 12. Potentiometric-level fluctuations, 1985-94, for boreholes USW WT-2 and UE-25 p\#1 at Yucca Mountain. 
Yucca Mountain (fig. 13). Maximum peak-to-peak fluctuations in response to nearby $(26 \mathrm{~km})$ earthquakes in late June 1992 were estimated to be $0.9 \mathrm{~m}$ for water levels and $2.2 \mathrm{~m}$ for fluid pressures (O'Brien, 1993, p. 8). These fluctuations generally lasted only 1 to 2 hours. Potentiometric levels in borehole UE-25 p\#1, however, declined a total of $0.5 \mathrm{~m}$ in response to these earthquakes (O'Brien, 1993, p. 10), and slowly recovered to pre-earthquake levels during the next 6 months (fig. 12).

Trend analyses were performed on potentiometric-level data for 1986 through 1989 by Ervin and others (1994). Earlier data were not used because of inconsistencies in measuring techniques in the waterlevel network. Results of their analyses need to be considered preliminary because of the relatively short period of record used. Four boreholes (USW WT-2, USW H-5, UE-25 WT\#6, and UE-25 WT\#16) had potentiometric-level changes that exhibited statistically significant trends. For 1986 through 1989 , the trend was positive, and ranged from 0.07 to $0.6 \mathrm{~m} / \mathrm{yr}$, indicating an upward change in potentiometric level.

The trends in boreholes UE-25 WT\#6 and UE-25 WT\#16 were probably attributable to postdrilling equilibration, based on the observation that hydrographs of potentiometric levels in these boreholes have shapes characteristic of recovery following pumping. The drilling process essentially pumped the boreholes dry. The long-term nature of the recovery trend indicated that the hydraulic conductivity in the vicinity of these boreholes was very small. The trends in the other two boreholes (USW WT-2 and USW H-5) are probably due to natural causes. As shown in figure 12, potentiometric levels in borehole USW WT-2 continued a slight overall upward trend through 1989 , were relatively stable in 1990-91, and began a slight downward trend through 1992. An updated trend analysis, using a longer period of record, might have different results than the results reported by Ervin and others (1994).

\section{Hydraulic Data}

Knowledge of hydraulic properties, such as hydraulic conductivity, transmissivity, and storativity, is critical to understanding the hydrogeology of Yucca Mountain and demonstrating compliance with regulatory requirements for a mined geologic repository. Such information also is required for numerical mod- els that can be used to simulate ground-water flow and contaminant transport. The following sections describe hydraulic data obtained from aquifer tests and from flow surveys in boreholes. A wide variety of methods were used to conduct and analyze these tests, with mixed success and results. No attempt is made in this report to evaluate or rank the results of the tests, and the reader is referred to the cited references for details.

\section{Aquifer Tests}

More than 150 individual aquifer tests were conducted at 13 boreholes (fig. 14) on and around Yucca Mountain in the early 1980's. Almost all the tests were single-borehole tests in specific depth intervals and included constant-discharge, fluid-injection, pressure-injection, borehole flow-meter, and radioactive-tracer tests. Multiple-borehole tests were conducted only at the C-hole complex (see "Local Hydrologic Setting" section). Results of aquifer tests usually were reported as transmissivity and hydraulic conductivity of intervals isolated with packers, but pumping-type aquifer tests were conducted in some boreholes for the entire saturated intervals. Storativity or specific yields were reported only for a few boreholes. Potential limitations of data collected during aquifer tests is discussed in the "Data Uncertainties" section.

Apparent hydraulic-conductivity values for the hydrogeologic units in the vicinity of Yucca Mountain are listed in table 4. These values were based on reported single-borehole aquifer tests and generally were calculated by dividing the total reported transmissivity of the tested interval by the thickness of that interval in the borehole. Hydraulic-conductivity values for individual intervals in a borehole could vary by several orders of magnitude, depending on whether or not water-bearing fractures were present. In intervals that contained no open fractures, hydraulic conductivity tended to be very low-generally less than $0.01 \mathrm{~m} / \mathrm{d}-$ reflecting the hydraulic conductivity of the rock matrix or of very small fractures. In tested intervals that contained water-bearing fractures, the apparent hydraulic-conductivity values listed in table 4 may be somewhat misleading; most, if not all, of the water produced in such an interval could have been produced by a few thin, highly conductive fractures in an otherwise thick, essentially nonproductive rock 



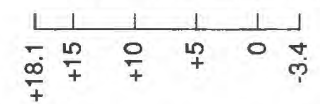

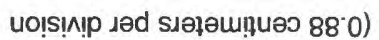
$\forall \exists \perp \forall M-1 O$ S $\forall \exists \perp \exists W I \perp N \exists O N I$ $' \exists$ SNOdS $\exists Y$ Y $7 \exists \wedge \exists 7-Y \exists \exists \perp \forall M$ $7 \forall \wedge \mathrm{H} \exists \perp \mathrm{NI} \forall \exists \exists d \mathrm{~d} \cap$

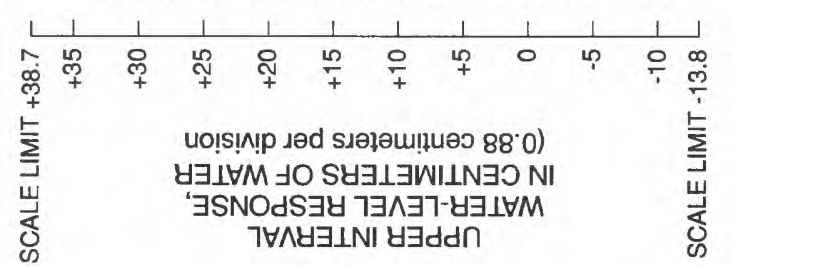

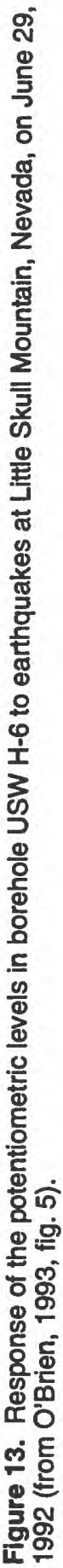




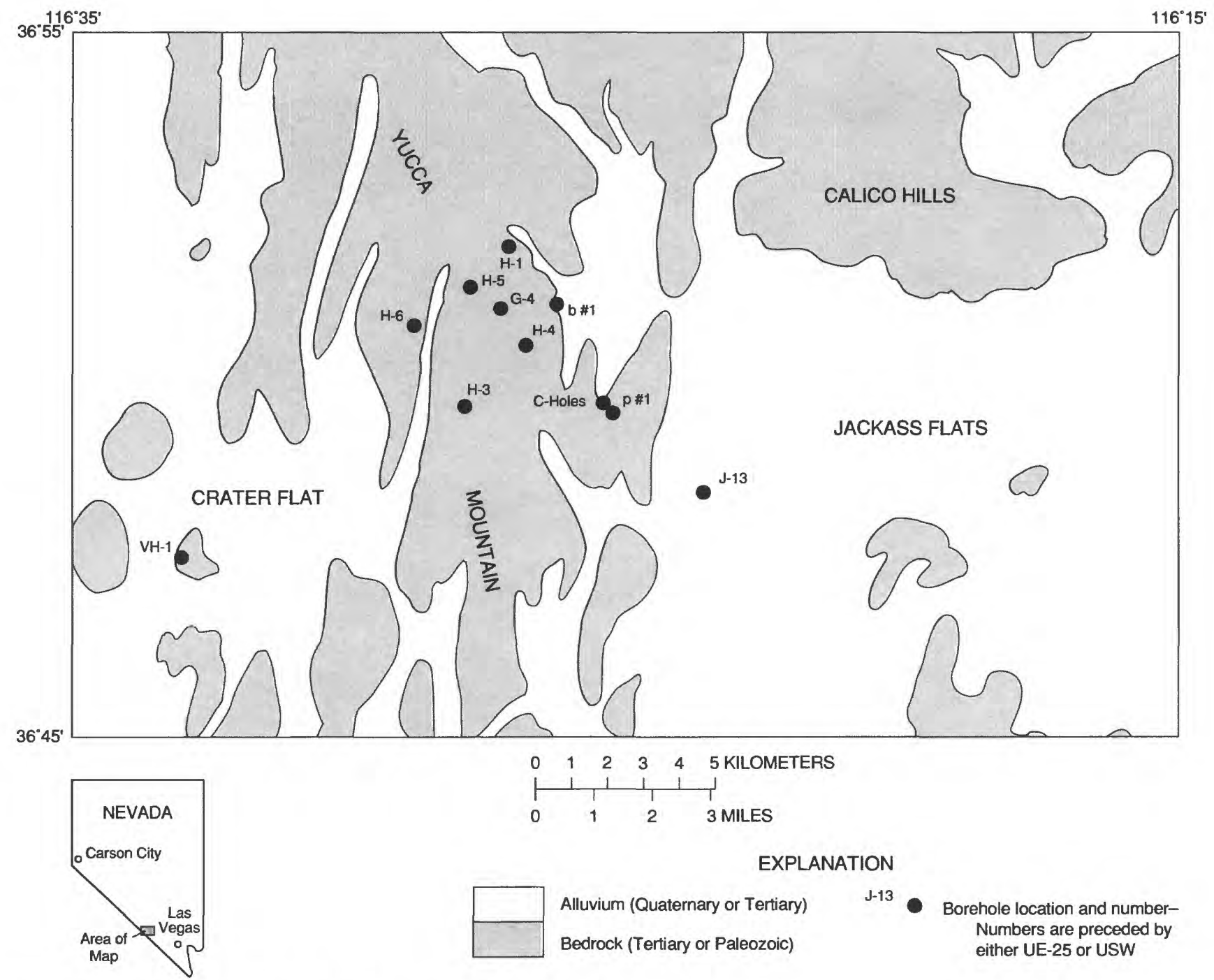

Figure 14. Locations of aquifer test data at Yucca Mountain. 
Table 4. Estimated apparent hydraulic-conductivity values obtained from single-borehole aquifer tests in the vicinity of Yucca Mountain

[-, no data available; $<$, less than]

\begin{tabular}{|c|c|c|c|c|c|c|}
\hline \multirow[b]{2}{*}{$\begin{array}{l}\text { Borehole } \\
\text { name }\end{array}$} & \multicolumn{5}{|c|}{ Apparent hydraulic conductivity, in meters par day } & \multirow[b]{2}{*}{ Reference } \\
\hline & $\begin{array}{l}\text { Uppar } \\
\text { volcanic } \\
\text { aquifer }\end{array}$ & $\begin{array}{c}\text { Uppar } \\
\text { volcanic } \\
\text { confining } \\
\text { unit }\end{array}$ & $\begin{array}{l}\text { Lower } \\
\text { volcanic } \\
\text { aquifer }\end{array}$ & $\begin{array}{c}\text { Lower } \\
\text { volcanic } \\
\text { confining } \\
\text { unit }\end{array}$ & $\begin{array}{l}\text { Carbonate } \\
\text { aquifer }\end{array}$ & \\
\hline USW H-1 & -- & -- & $4.3 \times 10^{-1}$ & $5.5 \times 10^{-6}$ & - & Rush and others (1984) \\
\hline USW H-3 & - & -- & $<3.7 \times 10^{-3}$ & $<3.2 \times 10^{-3}$ & - & Thordarson and others (1985) \\
\hline USW H-4 & -- & -- & $4.3 \times 10^{-1}$ & $1.1 \times 10^{-1}$ & - & Whitfield and others (1985) \\
\hline USW H-5 & -- & -- & $6.0 \times 10^{-1}$ & -- & - & Robison and Craig (1991) \\
\hline USW H-6 & -- & -- & $8.0 \times 10^{-1}$ & $1.8 \times 10^{-4}$ & - & Craig and Reed (1991) \\
\hline USW G-4 & -- & - & 1.4 & -- & -- & Lobmeyer (1986) \\
\hline UE-25 b\#1 & -- & $2.6 \times 10^{-1}$ & $4.9 \times 10^{-1}$ & $<1.0 \times 10^{-4}$ & -- & $\begin{array}{l}\text { Lahoud and others (1984); } \\
\text { Moench (1984) }\end{array}$ \\
\hline C-hole complex & - & $2.0 \times 10^{-2}$ & $7.0 \times 10^{-2}$ & - & -- & Geldon (in press) \\
\hline UE-25 p\#1 & - & -- & $3.3 \times 10^{-2}$ & $5.8 \times 10^{-3}$ & $1.9 \times 10^{-1}$ & Craig and Robison (1984) \\
\hline $\mathrm{J}-13$ & 1.0 & ${ }_{1}^{1.2} \times 10^{-1}$ & $7.6 \times 10^{-3}$ & $22.6 \times 10^{-3}$ & - & Thordarson (1983) \\
\hline
\end{tabular}

${ }^{1}$ Average determined from two tests.

${ }^{2}$ Includes part of the lower volcanic aquifer.

matrix. Therefore, hydraulic conductivity is termed "apparent" in this section.

Most hydraulic data were from tests conducted in the lower volcanic aquifer and in the lower volcanic confining unit. Very few data were available for the upper volcanic aquifer, the upper volcanic confining unit, and the carbonate aquifer.

Hydraulic data for the upper volcanic aquifer were available only for well J-13. Thordarson (1983) reported transmissivity (table 5) for geologic units that correspond to the upper volcanic aquifer of $120 \mathrm{~m}^{2} / \mathrm{d}$, which resulted in an apparent hydraulic-conductivity value of about $1.0 \mathrm{~m} / \mathrm{d}$ (table 4). The upper volcanic aquifer also was tested at borehole USW VH-1 (Thordarson and Howells, 1987); however, the tests were conducted over the entire saturated interval, which includes the lower volcanic aquifer. Most of the water produced by the borehole may be from a small part of the lower volcanic aquifer (Thordarson and Howells, 1987, p. 9). Reported transmissivity values ranged from 450 to $2,400 \mathrm{~m}^{2} / \mathrm{d}$ (Thordarson and Howells, 1987, p. 14-18), and apparent hydraulicconductivity values range from 0.8 to $4.2 \mathrm{~m} / \mathrm{d}$ for five tests at borehole USW VH-1.

Hydraulic data for the upper volcanic confining unit were available from tests conducted at the C-hole complex, borehole UE-25 b\#1, and well J-13. Reported transmissivity values for the upper volcanic confining unit ranged from 2.0 to $26 \mathrm{~m}^{2} / \mathrm{d}$ (table 5), and apparent hydraulic-conductivity values from tests at these boreholes ranged from 0.02 to $0.26 \mathrm{~m} / \mathrm{d}$ (table 4).

Reported transmissivity values of the lower volcanic aquifer ranged from less than 1.1 to $589 \mathrm{~m}^{2} / \mathrm{d}$ (table 5). The arithmetic mean of the 10 transmissivity values for the lower volcanic aquifer was about $152 \mathrm{~m}^{2} / \mathrm{d}$, and the geometric mean was about $43 \mathrm{~m}^{2} / \mathrm{d}$. Apparent hydraulic-conductivity values for the lower volcanic aquifer ranged from less than $3.7 \times 10^{-3}$ to $2.0 \mathrm{~m} / \mathrm{d}$ (table 4 ). The arithmetic mean of the $10 \mathrm{val}-$ ues in table 4 was $0.49 \mathrm{~m} / \mathrm{d}$ and the geometric mean was $0.15 \mathrm{~m} / \mathrm{d}$. In borehole USW H-1, apparent hydraulic conductivity of individual intervals tested in the lower volcanic aquifer ranged from $4 \times 10^{-5}$ to $18 \mathrm{~m} / \mathrm{d}$ (Rush and others, 1984) in single-borehole tests.

Reported transmissivity values of the lower volcanic confining unit ranged from less than $3.0 \times 10^{-3}$ to $23 \mathrm{~m}^{2} / \mathrm{d}$ (table 5). The arithmetic mean of the seven transmissivity values for the lower volcanic confining unit was $3.7 \mathrm{~m}^{2} / \mathrm{d}$ and the geometric mean was 0.20 $\mathrm{m}^{2} / \mathrm{d}$. Apparent hydraulic-conductivity values for the lower volcanic confining unit ranged from $5.5 \times 10^{-6}$ to $0.11 \mathrm{~m} / \mathrm{d}$ (table 4). The arithmetic mean of the seven values in table 4 was $1.7 \times 10^{-2} \mathrm{~m} / \mathrm{d}$, and the geometric mean was $1.3 \times 10^{-3} \mathrm{~m} / \mathrm{d}$. 
Table 5. Estimated transmissivity values obtained from single-borehole aquifer tests in the vicinity of Yucca Mountain

$[-$, no data; $<$, less than $]$

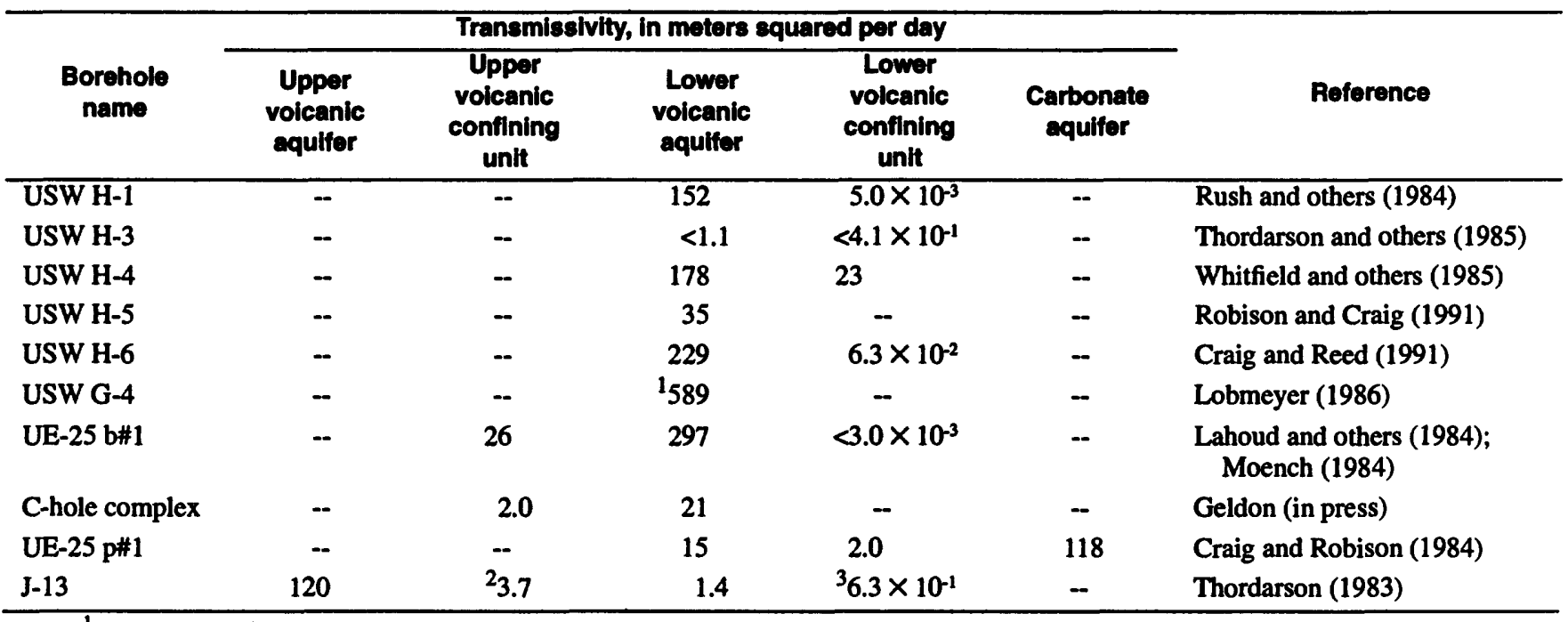

${ }^{1}$ Average determined from four tests.

${ }^{2}$ Average determined from two tests.

${ }^{3}$ Includes part of the lower volcanic aquifer.

Data were available for the carbonate aquifer in the vicinity of Yucca Mountain only for borehole UE-25 p\#1. Hydraulic data presented by Craig and Robison (1984) indicated a transmissivity of $118 \mathrm{~m}^{2} / \mathrm{d}$ (table 5) and apparent hydraulic-conductivity values for specific tested intervals that ranged from 0.1 to $0.2 \mathrm{~m} / \mathrm{d}$ and averaged $0.19 \mathrm{~m} / \mathrm{d}$.

In fractured-rock aquifers, such as those at Yucca Mountain, hydraulic conductivity probably is anisotropic - that is, greater in a direction parallel to the predominant fracture orientation than in other directions. Although this information is critical to determining the ground-water flow paths from the potential repository, only one test has been conducted at Yucca Mountain to determine whether or not the aquifers actually are anisotropic. Erickson and Waddell (1985, p. 24-29) reported that, at borehole USW H-4, the maximum hydraulic conductivity was from 5 to 7 times greater than the minimum hydraulic conductivity; the maximum hydraulic conductivity was oriented in a direction $23^{\circ}$ east of north. Czarnecki and Waddell (1984, p. 27-28), however, reported that their subregional model duplicated measured water levels more accurately when the aquifer was simulated as isotropic rather than anisotropic. Therefore, the question of anisotropy remains unre- solved. Future tests at the C-hole complex may help resolve this issue.

Vertical hydraulic-conductivity values were reported only for borehole USW H-5 and the C-hole complex. Robison and Craig (1991, p. 26) reported an apparent vertical hydraulic-conductivity value of $62 \mathrm{~m} / \mathrm{d}$ for the lower volcanic aquifer at borehole USW H-5. This value was about 100 times greater than the reported value for horizontal hydraulic conductivity of $0.6 \mathrm{~m} / \mathrm{d}$ (table 4). Data for the C-hole complex were in direct contrast with the data from borehole of USW H-5. The vertical hydraulicconductivity values for the lower volcanic aquifer were estimated to range from 1 to $2 \mathrm{~m} / \mathrm{d}$ (Geldon, 1996), and were from 0.01 to 0.17 times the values for the horizontal hydraulic conductivity $(6$ to $100 \mathrm{~m} / \mathrm{d}$ ) obtained over the same intervals using multipleborehole aquifer-test analyses.

Geldon (1996) reported that transmissivity and apparent hydraulic-conductivity values determined using multiple-borehole hydraulic tests tend to be much higher - about 2 orders of magnitude - than values reported for single-borehole tests conducted at the same borehole. For example, a single-borehole test at borehole UE-25 c\#3 resulted in a transmissivity value of $27.9 \mathrm{~m}^{2} / \mathrm{d}$, but results of a multiple-borehole test for the same test interval in the borehole indicated a 
transmissivity value of $1,860 \mathrm{~m}^{2} / \mathrm{d}$. Geldon (1996) concluded that multiple-borehole tests generally sample a much larger volume of the aquifer material and incorporate a larger number of water-bearing fractures than single-borehole tests. Because most transmissivity and hydraulic-conductivity values at Yucca Mountain were obtained from single-borehole tests, the values listed in tables 4 and 5 may not be representative values appropriate for scales of tens to hundreds of meters.

The hydraulic characteristics of a particular interval at a borehole are highly dependent on the fracture characteristics of that interval. A large conductive feature, such as the fault penetrated in the lower part of borehole UE- $25 \mathrm{c \# 1}$, can contribute a large percentage of the total flow to a borehole. The tested interval containing such a feature can have a disproportionately large transmissivity and apparent hydraulic conductivity compared to other intervals in the same borehole. Intervals that have few conductive fractures generally contribute little water to the borehole and may have small transmissivity compared to other intervals in the borehole.

The storativity reported for tests at the C-hole complex was 0.0005 , and specific yields ranged from 0.003 to 0.07 (Geldon, 1996). The boreholes at this complex tap the lower volcanic aquifer. Storativity for borehole USW H-1 was estimated by Rush and others (1984, table 12) to range from $6 \times 10^{-6}$ to $6 \times 10^{-3}$ for the lower volcanic aquifer and from $6 \times 10^{-4}$ to $2 \times 10^{-3}$ for the lower volcanic confining unit. Barr (1985) used the same data and obtained similar results. Thordarson and others (1985, table 2$)$ reported storativities for borehole USW $\mathrm{H}-3$ that ranged from $4 \times 10^{-6}$ to $7 \times 10^{-6}$ for the entire saturated interval of the borehole. Specific yields for borehole USW H-5 ranged from 0.15 to 0.28 (Robison and Craig, 1991, p. 24) for the entire saturated interval of the borehole; however, more than 95 percent of the water in the borehole was produced from fractures in the upper part of the lower volcanic aquifer (Robison and Craig, 1991, fig. 6). Barr (1991, table 3) estimated storativity for nine intervals in the lower volcanic aquifer in borehole USW G-4. The values ranged from $1 \times 10^{-5}$ to $8 \times 10^{-6}$.

\section{Flow Surveys}

Flow surveys were conducted in most of the deeper boreholes drilled at Yucca Mountain. Flow surveys are useful to determine which intervals of the borehole, and possibly which fractures, produced water. The flow surveys were conducted using a tool developed for oil-field use that releases small quantities of radioactive iodine-131 (Blankennagel, 1967, p. 15-19). As the iodine moves up or down the borehole, it is sensed by gamma-ray detectors. Most surveys are done while water is being pumped from or injected into the borehole. Static tests also were occasionally done.

Flow surveys are useful in determining which parts of the borehole produce (or accept) most of the flow. The information is useful when subdividing a system into aquifers and confining units. Minor producing intervals are not readily detected by this method. Flow surveys generally report velocities to about $0.03 \mathrm{~m} / \mathrm{s}$, but the variability between successive measurements is considerably larger than $0.03 \mathrm{~m} / \mathrm{s}$. Therefore, for borehole diameters generally found at Yucca Mountain, intervals producing less than $0.1 \mathrm{~L} / \mathrm{s}$ can be easily missed. Flow surveys for seven boreholes are shown in figure 15. For comparison purposes, the depths for all surveys were adjusted to a standard thickness of $524.3 \mathrm{~m}$ for the lower volcanic aquifer, which is the estimated thickness of this aquifer in borehole USW G-1, but is not necessarily representative of the thickness of the aquifer elsewhere.

The flow surveys generally indicated that production (or acceptance) of water occurred in a few intervals. Boreholes USW $\mathrm{H}-1$ and USW $\mathrm{H}-5$ are the most dramatic examples of this generalization. In borehole USW H-1, 64 percent of the production came from a $1-\mathrm{m}$ interval, whereas in borehole USW $\mathrm{H}-5$, 73 percent of the production came from a 42-m interval. Boreholes USW H-4 and UE-25 b\#1 had production from larger intervals. All of the boreholes had little production (or acceptance) of water from their lower intervals.

None of the boreholes for which flow surveys were done had major production from the lower volcanic confining unit, but borehole USW $\mathrm{H}-4$ produced about 12 percent of its flow from the uppermost part of that unit. The upper volcanic confining unit is saturated only in boreholes UE-25 b\#1 and USW G-2 (fig. 15). The upper confining unit produced approximately one-third of the water in borehole $\mathrm{UE}-25 \mathrm{b \# 1}$ and accepted virtually all the water in the test at borehole USW G-2. The lower volcanic aquifer did not accept any water in the test at borehole USW G-2 despite being fully penetrated. At the 


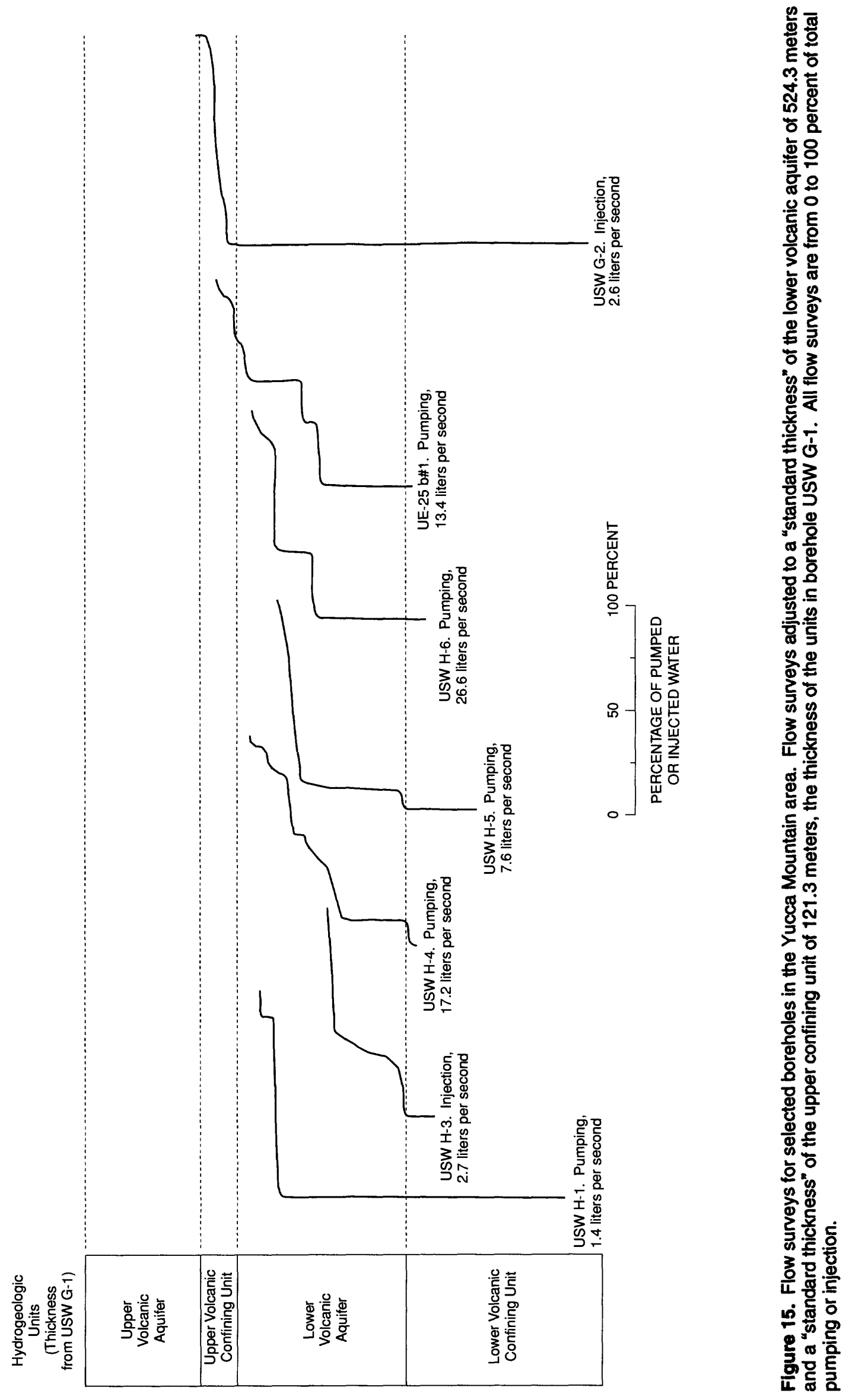


C-hole complex, flow surveys indicated that the lower volcanic aquifer produced virtually all the flow, but temperature surveys indicated that the upper volcanic confining unit produced some water in borehole UE-25 c\#3 and possibly in borehole UE-25 c\#2 (Geldon, 1993, figs. 31-33). The upper volcanic aquifer is above the saturated zone in all of the boreholes shown in figure 15. No flow surveys were available from boreholes that penetrated the upper volcanic aquifer in the saturated zone, but hydraulic tests at well J-13 indicated that most of the production was from the upper volcanic aquifer (Thordarson, 1983, table 12). At borehole USW VH-1 in Crater Flat, most of the production came from the lower volcanic aquifer (Thordarson and Howells, 1987, p. 9), whereas the upper volcanic aquifer produced little water. The upper volcanic confining unit is absent at this borehole.

\section{Inflow to Volcanic Flow System}

Sources of water that enter the volcanic aquifers and confining units in the vicinity of Yucca Mountain potentially include inflow from upgradient volcanic aquifers and confining units, local recharge from Fortymile Wash, precipitation that infiltrates the surface of Yucca Mountain, especially at higher altitudes at the northern end of Yucca Mountain, and upward flow from the underlying carbonate aquifer. The magnitudes of most of the inflows to the volcanic system have not been quantified.

\section{Upgradient Inflow}

Potentiometric data from widely spaced boreholes upgradient from Yucca Mountain indicate that ground water probably flows south from upland recharge areas in the volcanic terrain of Pahute and Rainier Mesas, beneath Timber Mountain, under the topographic divide near Pinnacles Ridge that separates Beatty Wash from Crater Flat and Yucca Mountain, continuing southward beneath the Yucca Mountain area (fig. 1). However, the concept of inflow from upgradient regions is based on limited data, particularly between Yucca Mountain and Pahute Mesa. The Timber Mountain caldera complex (fig. 2) lies between Pahute Mesa and Yucca Mountain. No data are available in the Timber Mountain area and its hydrologic characteristics are poorly known. The
Timber Mountain caldera complex could act as a barrier and divert upgradient flow away from the Yucca Mountain region and into Beatty Wash and the Oasis Valley ground-water subbasin. It is also possible, although not probable, that a ground-water divide exists between the Crater Flat-Yucca Mountain area and Beatty Wash. This possibility also would result in recharge from Pahute and Rainier Mesas being diverted into the Oasis Valley ground-water subbasin.

Hydrochemical data (Benson and others, 1983, table 1) indicated that water in the volcanic aquifer beneath Yucca Mountain and Crater Flat was recharged during wetter climatic conditions approximately 13,000 to 18,000 years ago based on apparent carbon-14 ages. However, these data do not preclude that some modern recharge occurs and in fact water from borehole UE-29 a\#2 in upper Fortymile Wash appeared to have been recharged about 4,000 years ago, whereas water from wells $\mathrm{J}-12$ and $\mathrm{J}-13$ have apparent ages of 9,000 and 10,000 years respectively. Actual ages may be older than apparent ages, and the water probably is a mixture from recharge events that spanned at least a number of millennia. The data do not indicate whether the recharge occurred far upgradient or in Fortymile Wash. If most of the ground water beneath Yucca Mountain was recharged in the distant past, the flow system may still be equilibrating from an ancient recharge pulse, resulting in a gradual decline in water levels beneath Crater Flat and Yucca Mountain over time (Czarnecki and others, 1990). This concept is consistent with the observation of Winograd and Szabo (1986) that water-levels apparently progressively declined in the southern Great Basin during the Quaternary Period, at least in the southern Amargosa Desert and in Death Valley.

\section{Fortymile Wash Recharge}

Fortymile Wash is a major southward-draining ephemeral channel located northeast, east, and southeast of Yucca Mountain (fig. 3). It is a long, linear feature that may be structurally controlled (note the long, straight canyon between Yucca Mountain and Calico Hills on the second page of fig. 1). Fortymile Wash begins to the north of Yucca Mountain in the highlands of Pahute Mesa and ends in the Amargosa Desert to the south of the mountain. During extreme runoff, Fortymile Wash would be tributary to the Amargosa River. In various numerical ground-water flow models (Czarnecki and Waddell, 1984; Rice, 1984; 
Czarnecki, 1985; Sinton, 1987), recharge had to be specified in Fortymile Wash to replicate potentiometric-level measurements in observation boreholes near Yucca Mountain. Czarnecki (1985) specified about 40 percent of the total recharge to his model as occurring in Fortymile Wash. Simulated potentiometric levels beneath Yucca Mountain were quite sensitive to this specified recharge (Czarnecki, 1985). Osterkamp and others (1994) estimated average annual recharge along the entire 95-km length of Fortymile Wash (including Fortymile Canyon) to be about $4.22 \times$ $10^{6} \mathrm{~m}^{3}$, based on channel-geometry measurements and analyses with a precipitation/runoff simulator.

Depths to water beneath upper Fortymile Wash were as small as $16 \mathrm{~m}$ in borehole UE-29 UZN\#91 (Savard, 1994, p. 1810-1812) compared to about $283 \mathrm{~m}$ at well J-13 directly east of Yucca Mountain (Robison and others, 1988, p. 129). Savard (1994) indicated that recharge occurred in 1992 and 1993 at borehole UE-29 UZN\#91 and at nearby boreholes UE-29 a\#1 and UE-29 a\#2 based on rising water levels in each borehole following local precipitation and runoff.

Waddell (1984, table 4) obtained hydrochemical samples from boreholes UE-29 a\#1 and UE-29 a\#2.

Tritium and carbon-14 values from these samples indicated that apparently younger water was present at shallower depths in borehole UE-29 a\#1 (65.5 m deep) compared to borehole UE-29 a\#2 (421.5 m deep). Younger water at shallow depth with deeper older water indicated that recharge was occurring at or near this site. In addition, the potentiometric level was about $4 \mathrm{~m}$ higher in the shallower borehole (UE-29 a\#1) than in the deeper borehole (UE-29 a\#2) which was consistent with recharge in this area.

Infrequently, Fortymile Wash has carried water to western Jackass Flats and even less frequently into the Amargosa Desert (Squires and Young, 1984). Water flowing down Fortymile Wash quickly infiltrates into the channel deposits; therefore, major flows need to occur for water to reach the lower sections. Such a major flow has not occurred during the site characterization of Yucca Mountain ${ }^{4}$; the last major

\footnotetext{
${ }^{4} \mathrm{Just}$ as this report was nearing completion in March 1995, flow occurred in Fortymile Wash at least as far downstream as well J-13. No definitive analysis of this recharge event has been completed although boreholes UE-29 a\#1, UE-29 a\#2, and UE-29 UZN\#91 showed significant water-level rise (C.S. Savard, U.S. Geological Survey, written commun., May 1995).
}

flow occurred in February 1969. No estimates of the volume of water recharged or the effects on water levels are available. As noted earlier in this section, Savard (1994) documented five small recharge events in 1992 and 1993 in Fortymile Wash or in its tributaries upstream from Jackass Flats.

\section{Local Infiltration}

Local infiltration from precipitation probably occurs in the Yucca Mountain area, but the amount of infiltration that reaches the water table may be inconsequential compared to the upgradient inflow and recharge from Fortymile Wash. Flint and Flint (1994) estimated that near-surface infiltration ranged from 0.02 to $13.4 \mathrm{~mm} / \mathrm{yr}$ and averaged $1.4 \mathrm{~mm} / \mathrm{yr}$. Higher infiltration tended to occur on the northern part of Yucca Mountain. Bodvarsson and others (1994), in a series of simulations of flow in the unsaturated zone, assumed average infiltration below the root zone over Yucca Mountain to be from 0.001 to $0.5 \mathrm{~mm} / \mathrm{yr}$. Deep infiltration would be less than shallow infiltration because air flow through the mountain would remove some moisture. Although accurate determination of the rate and distribution of percolation deep in the unsaturated zone at Yucca Mountain is important to predicting potential repository performance, this rate may be small enough under modern climatic conditions not to have a substantial effect on the saturatedzone flow system. If Flint and Flint's (1994) average shallow infiltration of $1.4 \mathrm{~mm} / \mathrm{yr}$ was assumed to reach the water table beneath the entire $150-\mathrm{km}$ area of intensive unsaturated-zone hydrologic study, recharge would amount to about $2 \times 10^{5} \mathrm{~m}^{3}$. While it is unlikely that all of the shallow infiltration becomes recharge, local infiltration to the saturated zone cannot be neglected until either better estimates of deep percolation are available or numerical models are shown to be insensitive to the assumed range in values of local recharge.

\section{Inflow From the Carbonate Aquifer}

As discussed in the "Vertical Hydraulic Gradients" section, the potentiometric level relation between the volcanic flow system and the carbonate aquifer is known only by measurement at borehole UE-25 p\#1 in the Yucca Mountain area. At a depth of about $1,100 \mathrm{~m}$ in the borehole, there was an upward gradient of about $18 \mathrm{~m}$ in $66 \mathrm{~m}$ between the lower 
volcanic confining unit and the carbonate aquifer, indicating the potential for upward flow. This potential does not necessarily mean that upward flow occurs, but the presence of calcified tuff in the lower part of the lower volcanic confining unit strongly indicates that upward flow actually occurred, at least in the past (Carr, M.D., and others, 1986, p. 24).

The "Vertical Hydraulic Gradients" section also discusses a substantial upward gradient between the deeper part of the lower volcanic confining unit and the overlying volcanic hydrogeologic units at four boreholes at Yucca Mountain, USW H-1, USW H-3, USW H-5, and USW H-6. The potentiometric difference exceeds $50 \mathrm{~m}$ in borehole USW H-1. In the "Vertical Hydraulic Gradients" section, the potentiometric levels in these boreholes are indicated as being a possible reflection of potentiometric levels in the carbonate aquifer, which is additional evidence for potential inflow from the carbonate aquifer.

Temperature measurements from the upper saturated zone indicated anomalies (elevated temperatures) around Solitario Canyon Fault and in the area between the Bow Ridge and Paintbrush Canyon Faults (Fridrich and others, 1994, fig. 8). These anomalies have been interpreted as evidence of upward flow from the carbonate aquifer (W.W. Dudley, Jr., U.S. Geological Survey, written commun., 1991; Fridrich and others, 1991, 1994). However, no quantitative estimates of rates for the postulated flow have been made.

Strontium isotopic data gives some evidence of upward flow from the carbonate aquifer into the volcanic system (Spengler and Peterman, 1991, p. 1420). This evidence, by itself, is not definitive, and no quantitative estimate of flow rates has been made.

\section{Outflow From Volcanic Flow System}

Pathways by which water may leave the volcanic aquifers and confining units in the vicinity of Yucca Mountain include outflow to downgradient volcanic aquifers and confining units and to the alluvial aquifer, pumpage, downward flow to the underlying carbonate aquifer, and upward flow into the unsaturated zone. The magnitudes of most of the outflows from the volcanic system have not been quantified.

\section{Downgradient Outflow}

Downgradient from Yucca Mountain in the Amargosa Desert, the potentiometric surface slopes gently toward the south (Czarnecki and Waddell, 1984, fig. 3; D’Agnese, 1994, fig. 10-3), indicating southerly ground-water flow. The potentiometric surface steepens in the vicinity of the Nevada-California State line, but flattens toward Alkali Flat (Franklin Lake Playa), as it approaches and possibly even rises above the land surface. Much of the downgradient flow probably discharges at this playa, although some flow probably continues southward beyond the playa.

\section{Pumpage}

Water is routinely pumped from wells $\mathrm{J}-12$ and $\mathrm{J}-13$ in Jackass Flats for use in the Yucca Mountain area and the southwestern part of the Nevada Test Site. Well J-12 was completed in 1957 and was placed in service in 1960, and well J-13 was placed in service shortly after it was completed in 1963. A third well in Jackass Flats, J-11, was completed in 1957, but was removed from service in 1962 because of poor water quality and casing problems (Young, 1972, p. 17). Young (1972, p. 13) estimated that about $6.9 \times$ $10^{5} \mathrm{~m}^{3} / \mathrm{yr}$ of water was pumped from these wells during 1962-67. LaCamera and Westenburg (1994, table 6) estimated that about $1.8 \times 10^{5} \mathrm{~m}^{3} / \mathrm{yr}$ of water was pumped from these wells during 1981-92. The decrease in pumpage with time was due to a decrease in activity in this part of the Nevada Test Site.

Water was pumped from various boreholes in the Yucca Mountain area during 1980-84 to determine the hydraulic characteristics of the flow system. The largest volume test occurred at borehole UE- $25 \mathrm{c \# 3}$ in November 1984 (Geldon, 1993, p. 25) where about $3.2 \times 10^{4} \mathrm{~m}^{3}$ of water was pumped. In March 1992, borehole JF-3 south of well J-12 was tested. About $2 \times 10^{3} \mathrm{~m}^{3}$ of water was pumped during that test (R.J. LaCamera, U.S. Geological Survey, oral commun., 1994).

Water is occasionally pumped from borehole USW VH-1 in Crater Flat, but the volume pumped is small. Elsewhere in Crater Flat, water is pumped to support mining operations. LaCamera and Westenburg (1994, table 6) estimated that about $6.9 \times 10^{4} \mathrm{~m}^{3} / \mathrm{yr}$ was pumped in Crater Flat during 1989-92. Water was pumped during various tests of borehole USW H-6 in 1982 and 1984 (Craig and 
Reed, 1991, p. 9-17). The total volume pumped was about $2.5 \times 10^{4} \mathrm{~m}^{3}$.

By far, the largest amount of pumpage in the area occurs in the Amargosa Desert south of Yucca Mountain. Water is pumped for irrigation, mining, industrial, commercial, stock, and domestic use. LaCamera and Westenburg (1994, table 6) compiled pumpage inventories by the Nevada Division of Water Resources for the Amargosa Desert for various years. Average pumpage for $1985-92$ was $8.1 \times 10^{6} \mathrm{~m}^{3} / \mathrm{yr}$ and ranged from $4.8 \times 10^{6}$ to $11.9 \times 10^{6} \mathrm{~m}^{3} / \mathrm{yr}$. Pumpage in the Amargosa Desert is more than $\mathbf{4 0}$ times as large as pumpage in the Yucca Mountain area. This pumpage probably does not have a direct effect on the flow system at Yucca Mountain because of the large distances involved, but probably needs to be accounted for during any modeling of the area. If a model of the Yucca Mountain area extends well into the Amargosa Desert, the pumpage needs to be accounted for directly. If a model does not extend that far south, the pumpage may be accounted for with boundary conditions.

\section{Outflow to the Carbonate Aquifer}

Limited evidence discussed in the "Inflow from the Carbonate Aquifer" section indicated that the carbonate aquifer may supply at least some inflow to the volcanic system at the south end of Yucca Mountain. There is no direct evidence that the volcanic system supplies outflow to the carbonate aquifer in the vicinity of Yucca Mountain. However, one explanation for the large hydraulic gradient at the northern end of Yucca Mountain assumes a major outflow from the volcanic system into the carbonate aquifer (see the "Large Hydraulic Gradient" section). Because of the sparseness of the data, it cannot be determined if there is any outflow from the volcanic system to the carbonate aquifer. If there is an outflow to the carbonate aquifer, it still cannot be determined whether there is a net outflow from the volcanic system to the carbonate aquifer or whether there is a net inflow to the volcanic system from the carbonate aquifer.

\section{Flow Into Unsaturated Zone}

The interaction between the water table and the overlying unsaturated zone at Yucca Mountain is being intensively studied. A conceptual model of the unsaturated zone (Montazer and Wilson, 1984) indi- cated a very small downward flux of water deep in the unsaturated zone. Ross (1984) studied vapor movement in the unsaturated zone where little recharge occurred and concluded that vapor movement could dominate the system, and upward flow could occur where net recharge was less than $0.03 \mathrm{~mm} / \mathrm{yr}$. Whatever the interaction between the saturated zone and the unsaturated zone at Yucca Mountain, the volume probably is small compared to downgradient outflow.

\section{Hydrochemicai Data}

Hydrochemical data describing saturated-zone ground water at and in the vicinity of Yucca Mountain date from 1971. Benson and McKinley (1985) reported chemical and isotopic information from 12 boreholes drilled between October 1980 and July 1984 (table 6). They also reported analyses of 1971 samples from two water-supply wells near Yucca Mountain. Matuska (1989) reported analyses of samples collected in 1988 from five boreholes, which penetrated the uppermost part of the flow system. Additional data for samples from more than 250 sites in the adjacent region were selectively compiled by McKinley and others (1991). Thomas and others (1991) compiled new and existing data for 209 sites in southern and eastern Nevada and adjacent southeastern California. The records for these sites, some of which are included in McKinley and others (1991), are fairly comprehensive and include all of the chemical and isotopic data available for each site until about 1989. Peterman and Stuckless (1993) and Ludwig and others (1993) presented and discussed strontium and uranium isotopic data, some of which are from Yucca Mountain area boreholes and springs. Perfect and others (1995) compiled data for more than 3,000 sites in the region between latitudes $35^{\circ}$ and $38^{\circ} \mathrm{N}$. and longitudes $115^{\circ}$ and $118^{\circ} \mathrm{W}$. This data set contains data for all the sites identified in the preceding references, but individual analyses reported may be less complete than in the less extensive compilations.

Data reported by Benson and McKinley (1985) included values of $\mathrm{pH}$, water temperature, and specific conductance; concentrations of major ions, lithium (Li), strontium ( $\mathrm{Sr}$ ), and dissolved solids; activities of tritium $\left({ }^{3} \mathrm{H}\right)$ and carbon-14 $\left({ }^{14} \mathrm{C}\right)$; and ratios of stable carbon, hydrogen, and oxygen isotopes. The Matuska (1989) data included the same suite, but without $\mathrm{Sr}$ and dissolved solids, and added bromide $(\mathrm{Br})$ and 
Table 6. Boreholes in the vicinity of Yucca Mountain from which hydrochemical data were obtained

[All depths are in meters below land surface]

\begin{tabular}{|c|c|c|c|c|c|c|}
\hline $\begin{array}{c}\text { Borehole } \\
\text { name }\end{array}$ & Latitude & Longltude & Totel depth & Depth to water & $\begin{array}{l}\text { Interval } \\
\text { sampled }\end{array}$ & $\begin{array}{c}\text { Date } \\
\text { sampled }\end{array}$ \\
\hline $\mathrm{J}-12$ & $36^{\circ} 45^{\prime} 54^{\prime \prime}$ & $116^{\circ} 23^{\prime} 24^{\prime \prime}$ & 347 & 226 & $226-347$ & $03 / 26 / 71$ \\
\hline $\mathrm{J}-13$ & $36^{\circ} 48^{\prime} 28^{\prime \prime}$ & $116^{\circ} 23^{\prime} 40^{\prime \prime}$ & 1,060 & 283 & $\begin{array}{l}304-424 ; \\
820-1,010\end{array}$ & $03 / 26 / 71$ \\
\hline \multirow[t]{2}{*}{ UE-25 b\#1 } & $36^{\circ} 51^{\prime} 08^{\prime \prime}$ & $116^{\circ} 26^{\prime} 23^{\prime \prime}$ & 1,220 & 470 & $470-1,220$ & $09 / 01 / 81$ \\
\hline & & & & & $853-914$ & $07 / 20 / 82$ \\
\hline UE-25 c\#1 & $36^{\circ} 49^{\prime} 47^{\prime \prime}$ & $116^{\circ} 25^{\prime} 43^{\prime \prime}$ & 914 & 401 & $401-914$ & 09/30/83 \\
\hline UE-25 c\#2 & $36^{\circ} 49^{\prime} 45^{\prime \prime}$ & $116^{\circ} 25^{\prime} 43^{\prime \prime}$ & 914 & 401 & $401-914$ & 03/13/84 \\
\hline UE-25 c\#3 & $36^{\circ} 49^{\prime} 45^{\prime \prime}$ & $116^{\circ} 25^{\prime} 44^{\prime \prime}$ & 914 & 402 & $402-914$ & 05/09/84 \\
\hline \multirow[t]{2}{*}{ UE-25 p\#1 } & $36^{\circ} 49^{\prime} 38^{\prime \prime}$ & $116^{\circ} 25^{\prime} 21^{\prime \prime}$ & 1,805 & 382 & $382-1,173$ & $02 / 11 / 83$ \\
\hline & & & & & $1,298-1,792$ & $05 / 12 / 83$ \\
\hline \multirow[t]{2}{*}{ UE-29 a\#2 } & $36^{\circ} 56^{\prime} 29^{\prime \prime}$ & $116^{\circ} 22^{\prime} 26^{\prime \prime}$ & 422 & 28 & $247-355$ & $01 / 08 / 82$ \\
\hline & & & & & $87-213$ & $01 / 15 / 82$ \\
\hline \multirow[t]{2}{*}{ USW H-1 } & $36^{\circ} 51^{\prime} 57^{\prime \prime}$ & $116^{\circ} 27^{\prime} 12^{\prime \prime}$ & 1,829 & 572 & $572-687$ & $10 / 20 / 80$ \\
\hline & & & & & $687-1,829$ & $12 / 08 / 80$ \\
\hline USW H-3 & $36^{\circ} 49^{\prime} 42^{\prime \prime}$ & $116^{\circ} 28^{\prime} 00^{\prime \prime}$ & 1,219 & 751 & $754-1,219$ & $03 / 14 / 84$ \\
\hline USW H-4 & $36^{\circ} 50^{\prime} 32^{\prime \prime}$ & $116^{\circ} 26^{\prime} 54^{\prime \prime}$ & 1,219 & 519 & $519-1,219$ & $05 / 17 / 82$ \\
\hline USW H-5 & $36^{\circ} 51^{\prime 2} 22^{\prime \prime}$ & $116^{\circ} 27^{\prime} 55^{\prime \prime}$ & 1,219 & 704 & $707-1,219$ & $07 / 03 / 82$ \\
\hline \multirow[t]{3}{*}{ USW H-6 } & $36^{\circ} 50^{\prime} 49^{\prime \prime}$ & $116^{\circ} 28^{\prime} 55^{\prime \prime}$ & 1,220 & 527 & $527-1,220$ & $10 / 16 / 82$ \\
\hline & & & & & $600-650$ & 07/06/84 \\
\hline & & & & & $753-835$ & 06/20/84 \\
\hline USW VH-1 & $36^{\circ} 47^{\prime} 32^{\prime \prime}$ & $116^{\circ} 33^{\prime} 07^{\prime \prime}$ & 762 & 184 & $278-762$ & $02 / 11 / 81$ \\
\hline
\end{tabular}

some nitrate $\left(\mathrm{NO}_{3}\right)$ and detergent [methylene blue activated substance (MBAS)]. Duplicates of most of the Matuska (1989) samples were obtained by the USGS and independent analytical results were essentially the same.

The major-ion data of Benson and McKinley (1985) and Matuska (1989) may be subject to question, because $\mathrm{Li}$ concentrations in all except one of the samples ranged from 1.5 to more than 20 times the concentration in samples from nearby, heavily pumped water-supply well J-13. The concentration of Li may indicate the presence of contamination because $\mathrm{LiBr}$ was added as a tracer to air-foam fluids used in drilling the sample borehole. This information, and field observations of sample turbidity and foaming, indicated incomplete removal of drilling fluid prior to sample collection. This possible contamination also raised questions about the carbon-isotope data because the drilling fluid used in drilling the boreholes was an air-water-detergent mixture.

Stuckless, Whelan, and Steinkampf (1991) used the Benson and McKinley (1985) and Matuska (1989) carbon-isotope data in mixing calculations to interpret measured variations in carbon-isotopic data and indicated the presence of at least three end-member waters. The presence of these end-member waters is not supported by ground-water flow that can be inferred from potentiometric data, nor do similar mixing calculations using nonreactive ionic concentrations or hydrogen- or oxygen-isotopic ratios provide support for these three end members. Peterman and Stuckless (1993) reported a general north-to-south increase in borehole and spring strontium isotopic values $\left(\delta^{87} \mathrm{Sr}\right)$ from Pahute Mesa to the southern Amargosa Desert, but could not describe regional flow paths beyond the flow paths that can be inferred from regional potentiometric data. The $\delta^{87} \mathrm{Sr}$ data provided no insight as to flow paths at and in the immediate vicinity of Yucca Mountain. Peterman and Stuckless (1993) attributed this inability to determine flow paths to the isotopic stratification identified in the lithologic units and inhomogeneities along the flow paths due to structural and lithologic variations. 
The chemical characteristics of ground water in the Yucca Mountain area have evolved primarily from rock/water interactions. Ground-water composition is a function of recharge water chemistry and the materials with which the water interacts along its flow path. Ground-water cations in the volcanic system derive from reaction with volcanic glass, primary minerals, soils, and probably to some extent, secondary phases such as calcite. In addition to being derived from rock/water interaction, anions derive from atmospheric, soil-zone and unsaturated-zone gases, and precipitation. From the available information (Benson and McKinley, 1985; Matuska, 1989; Thomas and others, 1991), water in the volcanic aquifers and confining units is a relatively dilute sodium bicarbonate type that would be expected to evolve in a volcanic geohydrologic system (Jones, 1966).

The Benson and McKinley (1985) and Matuska (1989) data indicated that the calcium sodium ratio in the water increased by an order of magnitude from west to east at Yucca Mountain, the lowest values being west of and near the Solitario Canyon Fault. This increase in ratio indicated that the chemical evolution of the water had progressed farther in the water to the west. This evolution to the west could be the combined effect of the Solitario Canyon Fault acting as a barrier to horizontal flow from the west, the cause of the large hydraulic gradient acting as a barrier to horizontal flow from the north, and less evolved water moving from in the vicinity of Fortymile Wash mixing with more evolved water moving from the west. This evolution also could indicate a contribution of water from the underlying Paleozoic aquifer to the volcanic system through faults on the east side of Yucca Mountain, without substantial upwelling of deeper water through Solitario Canyon Fault. Apparent carbon-14 $\left({ }^{14} \mathrm{C}\right)$ ages from Benson and McKinley (1985) indicate the oldest water occurs beneath the crest of Yucca Mountain and the youngest water occurs beneath Fortymile Wash. The Benson and McKinley (1985) data were from samples obtained generally from considerably below the water table, whereas the Matuska (1989) data were from water that was from the uppermost $100 \mathrm{~m}$ of the saturated zone.

The variation in water chemistry is indicated in the exchange-ion compositions of clinoptilolites, a zeolite, examined by Broxton and others (1987, p. 98). In their Zone II (see "Zeolites and the Water Table" section), the uppermost part of which contains the modern-day potentiometric surface, sodium $(\mathrm{Na})$ and potassium (K) occupy most of the zeolite-exchange sites from the west part of Yucca Mountain, grading to a predominance by calcium $(\mathrm{Ca})$, magnesium $(\mathrm{Mg})$, and potassium $(\mathrm{K})$ in zeolite-exchange sites to the east. Most of the clinoptilolites Broxton and others (1987) examined were from below the water table. Those clinoptilolites from above the water table tended to contain $\mathrm{K}$ in the zeolite-exchange sites. Broxton and others (1987, p. 96) also pointed out that zeolites in Zone I, all in or above the Topopah Spring Tuff, have primarily $\mathrm{Ca}$ in the zeolite-exchange sites, whereas the parent rock is relatively Ca poor. If these zeolites formed because of stratigraphically-related changes in permeability that could result in liquid accumulations parallel to the contrasts, the calcic nature of the zeolites could be attributed to dissolution of secondary calcite caused by zeolite formation that began once percolating water attained sufficiently high $\mathrm{K}, \mathrm{Na}$, and silicon ( $\mathrm{Si}$ ) activities (Broxton and others, 1987, p. 105).

Hydrochemical and isotopic data, where adequate data are available, can provide qualitative information for checking numerical flow models. The numerical models can be used to identify potential flow paths through and between the volcanic and carbonate flow systems. The hydrochemical data then can be used to support or refute the potential flow paths by analyzing the evolution of the water along the potential flow path. The numerical models can be used to calculate residence time of water in the flow system. The residence time can be checked by comparing estimated and actual concentrations of selected hydrochemical constituents and isotopic ratios.

\section{Paleohydrology}

Previous sections of this report have described the ground-water flow system as it existed during modern times. Modern ground-water conditions are the result of the modern climate or the climate of the recent geologic past (tens of thousands of years). However, climate is dynamic and different climates in the past would have resulted in differences in the flow system.

Spaulding (1985) and Forester and Smith (1994) stated that the modern climate of southern Nevada is very atypical and that wetter and cooler climates have been normal in the geologic past. Evidence of the effects of wetter and cooler climates on the ground- 
water flow system is preserved in discharge deposits around Yucca Mountain (Winograd and Doty, 1980; Paces and others, 1993) and, to some extent, also in some types of geochemical alteration of tuffs in Yucca Mountain.

In addition to climate-driven changes, Szymanski (1989) has suggested that stress- and thermally-driven effects [seismic pumping or Sibson pumping (Sibson and others, 1975)] have dramatically altered the flow system in the geologic past. Szymanski (1989) suggested that the water table at and in the vicinity of Yucca Mountain has been dramatically higher, even reaching the land surface, in the past as a result of cyclical tectonism. To address this concern, geologic, hydrologic, isotopic, tectonic, and thermal information has been examined by numerous investigators, including Quade and Cerling (1990), Carrigan and others (1991), Marshall and Mahan, (1991), National Research Council (1992), Stuckless, Peterman, and Muhs (1991), and Whelan and Stuckless (1992). These investigators studied the Szymanski (1989) model in considerable detail and rejected its important aspects. Dudley and others (1989) provided a summary of all of the reviews of the Szymanski model. Because this complex and controversial model was examined and rejected by previous investigators, it is not considered further in this report.

\section{Northern Discharge Deposits}

Three carbonate-rich, apparent spring discharge deposits are present in the southern end of Crater Flat and the northern end of the Amargosa Desert, approximately $18 \mathrm{~km}$ southwest of the potential repository at Yucca Mountain (Paces and others, 1993). These deposits are termed the northern discharge deposits only to distinguish them from the deposits discussed in the next section. Data indicated that these discharge deposits were partly contemporaneous and were most likely part of the same hydrologic system. The deposits range widely in ages, but probably have resulted from active spring discharge within the last 19,000 to 150,000 years (E.M. Taylor, U.S. Geological Survey, oral commun., 1993; Paces and others, 1993). Uranium- and strontium-isotopic data indicated that the water in the volcanic aquifers (or alternately, alluvium derived from these volcanic rocks) provided the source for these spring discharge deposits. The water table may have been 80 to $115 \mathrm{~m}$ above its modern level at various times during the Quaternary Period
(Paces and others, 1993); however, the position of the water table beneath these deposits is not well known and needs to be determined. Even under modern climatic conditions, these spring discharge deposits frequently appear to be moist, which may indicate that they represent a perched-system discharge area.

These spring discharge deposits provide indirect information against which the numerical flow model, once it is developed, can be tested. If a numerical model predicts surface flow in these areas when wetter and cooler climatic conditions are imposed, confidence in the model would be increased. If surface flow cannot be reproduced under reasonable climatic conditions, then either the model has to be inadequate or the interpretation of the cause of these spring discharge deposits is in error.

\section{Southern Discharge Deposits}

Czarnecki (1985) simulated wetter climatic conditions using a subregional ground-water flow model of the Yucca Mountain area. According to the simulation, new or increased ground-water discharge as a result of wetter climatic conditions would occur: (1) South and west of Timber Mountain in Beatty Wash; (2) along Fortymile Canyon, resulting in perennial streamflow; (3) in the Amargosa Desert near the town of Amargosa Valley, about $10 \mathrm{~km}$ north of the town of Death Valley Junction, and at Alkali Flat (Franklin Lake Playa); and (4) near Furnace Creek Ranch in Death Valley. Field investigations near the predicted discharge areas in the Amargosa Desert indicated the presence of areally extensive marsh or spring discharge deposits at the land surface north of Death Valley Junction. These marsh or spring discharge deposits are being studied and dated and seem to have been active in the recent geologic past (Z.E. Peterman, U.S. Geological Survey, oral commun., 1995), but the deposits have not yet provided data to confirm the simulated ground-water discharge areas during wetter and cooler climatic conditions.

\section{Zeolltes and the Water Table}

Many studies concentrated on the presence and the chemical and isotopic attributes of the primary and secondary mineral phases in the upper volcanic sequence in the vicinity of Yucca Mountain. Bish and others (1981) and Smyth and Caporuscio (1981), using analyses of core from borehole USW G-1, 
subdivided the volcanic sequence vertically into four zones that were based on the vertical distribution of diagenetic minerals. The lowermost zones (III and IV) are at least $500 \mathrm{~m}$ below the potentiometric surface and are not relevant to this discussion.

Broxton and others (1987) extended the examination of secondary minerals in the Yucca Mountain area. They reported that Zone I ranges in thickness from about $550 \mathrm{~m}$ at borehole USW G-2 on the northern end of Yucca Mountain and at borehole USW G-3 on the southern end to about $170 \mathrm{~m}$ near the northern end of Yucca Mountain (fig. 16). At borehole USW G-1, Zone $I$ is about $380 \mathrm{~m}$ thick. The base of Zone I essentially coincides with the top of the Calico Hills Formation at the northern end of Yucca Mountain and is in or near the base of the formation elsewhere. Zone $I$ is above the water table everywhere and contains a large percentage of unaltered volcanic glass in vitric tuffs. Broxton and others (1987) reported that secondary mineralization in Zone $I$ is only incipient and consists primarily of smectite and opal. Alteration of pumice and glass shards is limited and, where present, is restricted to particle margins. The predominance of glass indicates that no part of Zone I has ever been below the water table because the glass would have altered rapidly and completely to secondary phases had it been in the saturated zone.

In Zone I, the presence of clinoptilolite, the first zeolite likely to form during post-depositional evolution, is restricted to localized fractures (Carlos, 1985) and to thin, discontinuous areas in mostly vitric tuffs that are parallel to the bedding, which indicate that these fractures and areas were the only sites of substantial and persistent liquid accumulation. These bedding-parallel zeolitic zones tend to be horizontally discontinuous, except for an ubiquitous smectitezeolite interval at the top of the basal vitrophyre of the Topopah Spring Tuff of the Paintbrush Group (D.L. Bish, Los Alamos National Laboratory, oral commun., 1993). Levy (1984a,b) suggested that this interval is the product of epithermal diagenesis that occurred soon after deposition. Alternatively, the interval could be the result of the accumulation of fluid at the large permeability contrast provided by the basal vitrophyre, which, in the absence of through-going conductive fractures, could essentially stop the vertical movement of water.

Another exception to limited alteration in Zone I is a 130-m interval in the lower part of the Yucca Mountain Tuff, the underlying Pah Canyon Tuff, and the upper part of the Topopah Spring Tuff. This interval has been identified only in borehole USW G-2. The base of the interval is about $300 \mathrm{~m}$ above the modern water table. Smectite is the predominant mineral in the upper one-half of this largely vitric interval; smectite- and clinoptilolite-group minerals are common in the lower one-half, and zeolites become predominant with increasing depth (Broxton and others, 1987, p. 93). This gradation of minerals indicates that permeability decreases with depth in this interval, and that the downward flow of water tends to be restricted. This interval probably was not associated with a regional water table, even under wetter and cooler climatic conditions.

Zone II (fig. 16) thickens from about $480 \mathrm{~m}$ in the vicinity of borehole USW G-2 to about $700 \mathrm{~m}$ in the vicinity of borehole USW G-3. It contains little volcanic glass, most of the glass has been altered to clinoptilolite- and mordenite-group minerals. The top of Zone II is essentially in the Calico Hills Formation, slopes downward south from borehole USW G-2, where it roughly coincides with the modern water table. South of borehole USW G-2, the water table is above the top of Zone II, about $150 \mathrm{~m}$ at boreholes USW G-1 and USW H-5, and $190 \mathrm{~m}$ at borehole USW G-3 (fig. 16). From borehole USW G-3 to boreholes USW H-5 and USW G-1, the top of Zone II essentially maintains an altitude of about $900 \mathrm{~m}$. At borehole UE-25 b\#1 (fig. 16), about $2 \mathrm{~km}$ east of a line between boreholes USW G-2 and USW G-3, the top of Zone II is at an altitude of about $800 \mathrm{~m}$, roughly $70 \mathrm{~m}$ above the modern water table (Broxton and others, 1987, fig. 3).

Broxton and others (1987) discussed two scenarios that could explain the presence of zeolites above the water table. One scenario is the formation of zeolites in the unsaturated zone by downwardpercolating water, the effect of which would be enhanced by the formation of perched water because of horizontally continuous permeability contrasts (Hoover, 1968). Another scenario is formation of zeolites below the water table followed by uplift of units by basin and range faulting into the unsaturated zone.

Peterman and others (1992) measured the relative abundances of strontium isotopes ${ }^{87} \mathrm{Sr}$ and ${ }^{86} \mathrm{Sr}$ ) in calcite samples from five boreholes (USW G-1, USW G-2, USW G-3, USW G-4, and UE-25 b\#1) and found three populations of isotopic ratios. Samples from within $400 \mathrm{~m}$ of land surface had values similar to samples of surficial pedogenic calcites. 


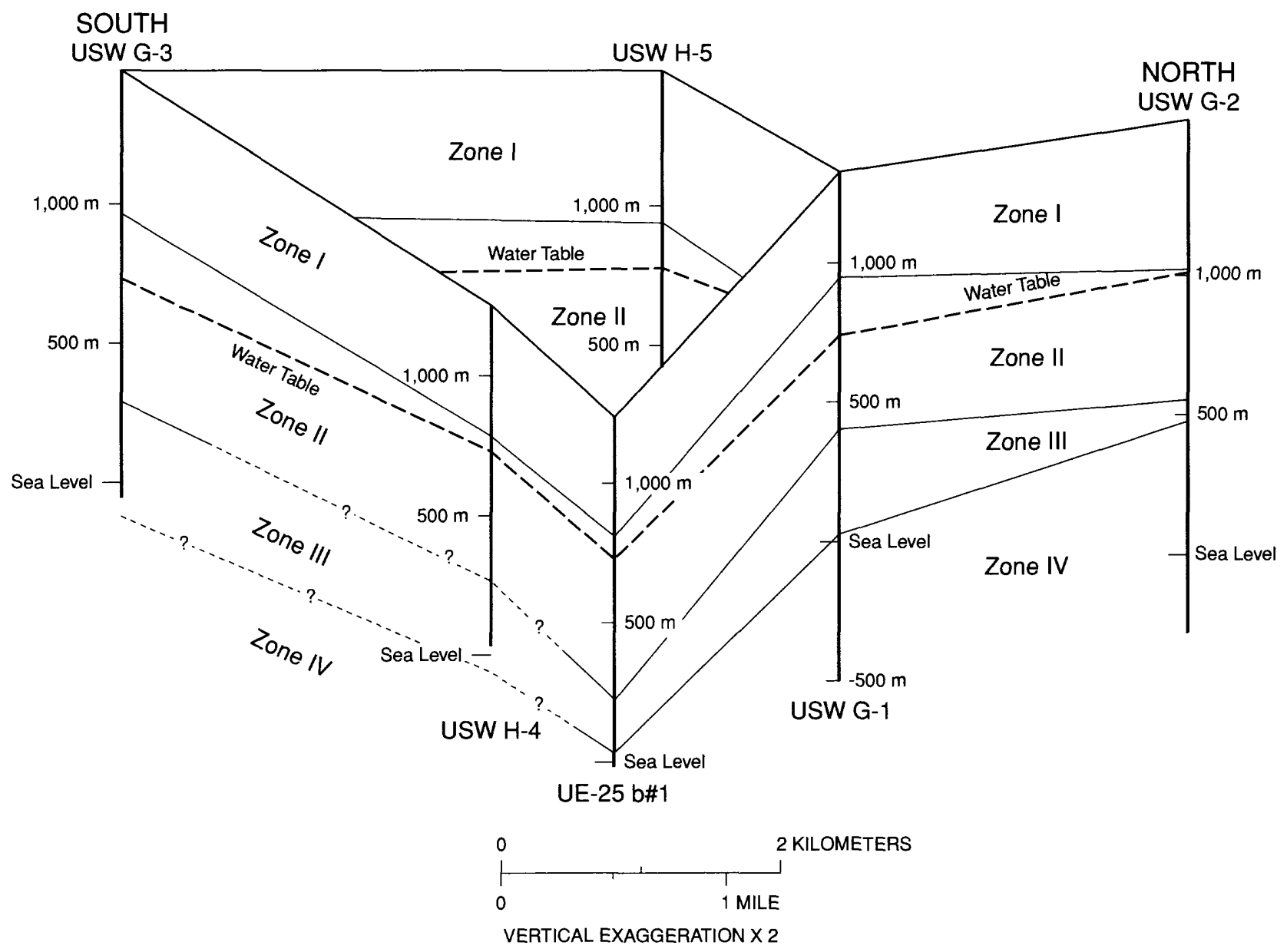

Figure 16. Diagenetic zones in the volcanic sequence at Yucca Mountain (modified from Broxton and others, 1987).

Samples obtained from within $100 \mathrm{~m}$ of the modern water table, all four of which came from borehole USW G-2, had values very close to the mean value for ground-water samples obtained from the volcanic flow system. Samples obtained from below the water table had isotopic ratios that were very close to the calculated initial isotopic values of the host volcanic rocks, but the values differed from the mean ground-water value and from values for calcites from above the water table. To explain these distinct differences, Peterman and others (1992) offered two scenarios. The first scenario is a higher water table in the past, which was supported by Marshall and others (1993). Marshall and others (1993) offered evidence for a higher water table at a site in southern Crater Flat about $15 \mathrm{~km}$ southwest of borehole USW G-3 (see "Northern Discharge Deposits" section). The second scenario is upward aqueous diffusion of $\mathrm{Ca}$ and $\mathrm{Sr}$ from the saturated zone. Peterman and others (1992) also suggested the possibility of contribution of $\mathrm{Ca}$ and $\mathrm{Sr}$ from underlying Paleozoic carbonates to the lower part of the volcanic sequence.

\section{LOCAL HYDROLOGIC SETTING (C-HOLE COMPLEX)}

On a local scale (ten to hundreds of meters), ground-water flow in the volcanic rocks beneath Yucca Mountain is likely to be controlled by fractures. Although many fractures exist in the various sections of the volcanic rocks, only a small percentage of the fractures actually conduct large quantities of water to most of the boreholes. Flow in these fractures 
probably occurs via the fortuitous intersection and interconnection of conductive pathways. Effects at the scale of as much as $100 \mathrm{~m}$ are being studied at the C-hole complex (U.S. Department of Energy, 1990a, sec. 3.3 through 3.5 ), which is the only multihole complex in the saturated zone at Yucca Mountain.

The C-hole complex consists of three boreholes (UE-25 c\#1, UE-25 c\#2, and UE-25 c\#3) located about $2.4 \mathrm{~km}$ east of the crest of Yucca Mountain, between Bow Ridge and Fran Ridge (fig. 17). The boreholes are located in a triangular pattern; boreholes UE-25 c\#1 and UE-25 c\#2 are along a line estimated to be the major semiaxis of the permeability tensor. Boreholes UE-25 c\#2 and UE-25 c\#3 are along a line estimated to be the minor semiaxis of the permeability tensor (U.S. Department of Energy, 1990a, p. 3.3-4). Each borehole was drilled to a depth of approximately $914 \mathrm{~m}$. The water table is approximately $402 \mathrm{~m}$ below the land surface, and the geologic units penetrated beneath the water table are the Calico Hills Formation and the Prow Pass, Bullfrog, and Tram Tuffs of the Crater Flat Group (fig. 18).

Understanding of ground-water flow at the C-hole complex is based primarily on dynamic (tracejector) and static (heat-pulse) intraborehole-flow surveys, borehole television and acoustic televiewer logs, and borehole temperature logs (Geldon, 1993). In general, flow at the complex is controlled by fractures, fracture zones, and faults. Although the entire tested thickness contains numerous fractures, only a small percentage of those fractures contribute measurable quantities of flow.

Intraborehole-flow surveys in response to natural gradients indicated that flow in the upper part of borehole UE-25 c\#1 was downward at a rate of approximately $0.01 \mathrm{~L} / \mathrm{s}$ to a depth of $768 \mathrm{~m}$. Below $768 \mathrm{~m}$, flow was upward at a rate of approximately $0.1 \mathrm{~L} / \mathrm{s}$. In borehole UE-25 c\#2, flow in the upper part of the borehole was downward at a rate of approximately $0.01 \mathrm{~L} / \mathrm{s}$ to a depth of about $823 \mathrm{~m}$. Below $823 \mathrm{~m}$, flow was upward at a rate of approximately $0.01 \mathrm{~L} / \mathrm{s}$. Flow in the upper part of borehole UE-25 c\#3 was upward at a rate of approximately $0.003 \mathrm{~L} / \mathrm{s}$ to a depth of about $701 \mathrm{~m}$. Below $701 \mathrm{~m}$, flow was upward at a rate of approximately $0.25 \mathrm{~L} / \mathrm{s}$, and below $870 \mathrm{~m}$, it was upward at a rate of approximately $0.13 \mathrm{~L} / \mathrm{s}$.

Although there are differences in flow rates in response to natural gradients, these surveys indicated several similarities among the three boreholes. Two features, a fault and a fracture zone, seemed to be controlling flow. The fault, interpreted by Geldon (1993, p. 39-42) to be the Paintbrush Canyon Fault or a splay of the fault, intersects each of the boreholes in the Tram Tuff, at a depth of about $853 \mathrm{~m}$. Warm water, indicating that the water may be coming from deeper in the flow system, seems to enter each borehole through this fault and flows upward until it reaches a fracture zone that intersects each borehole in the Bullfrog Tuff (Geldon, 1996). Most of the intraborehole flow exits the borehole through the fracture zone in the Bullfrog Tuff. Small amounts of water enter the upper part of boreholes UE-25 c\#1 and UE-25 c\#2 through a fracture zone near the contact between the Calico Hills Formation and the underlying Prow Pass Tuff of the Crater Flat Group. This water moves downward and also exits the borehole in the Bullfrog Tuff.

The differences in flow rates among the boreholes can be explained by assuming that borehole UE-25 $\mathrm{c \# 3}$ intersected the fault at a point where the fault zone had a large transmissivity. As a result of higher potentiometric head at depth, possibly derived from the underlying Paleozoic carbonate aquifer (Geldon, 1996), water moved upward along the fault. Although most of the water exited the borehole through the Bullfrog Tuff, the flow $(0.25 \mathrm{~L} / \mathrm{s})$ was too large for all the water to exit; thus, a residual upward flow $(0.003 \mathrm{~L} / \mathrm{s})$ occurred in the upper part of the borehole. In borehole UE-25 c\#1, water also entered through the same fault, but at a smaller rate $(0.1-0.2 \mathrm{~L} / \mathrm{s})$. At this smaller flow rate, the fracture zone in the Bullfrog Tuff had sufficient transmissivity to allow all water from below the zone to exit; as a result, flow above the fracture zone was downward from the flow zone in the Prow Pass Tuff. Flow in borehole UE-25 c\#2 was similar to that in borehole UE-25 c\#1, ecept that borehole UE-25 c\#2 intersected the fault where the transmissivity was smaller. Because of the smaller transmissivity, a much smaller flow (0.01-0.02 L/s) entered through the fault and moved up the borehole.

Two conceptual models could be used in designing and interpreting hydraulic and tracer tests at the C-hole complex. One conceptual model would treat each flow zone as an isolated permeable zone separated by zones of relatively small transmissivity. However, this model may not be appropriate because of the presence of the fault intersected by the boreholes at about $853 \mathrm{~m}$, but the possibility that the transmissivity of the fault may decrease east of the C-hole 


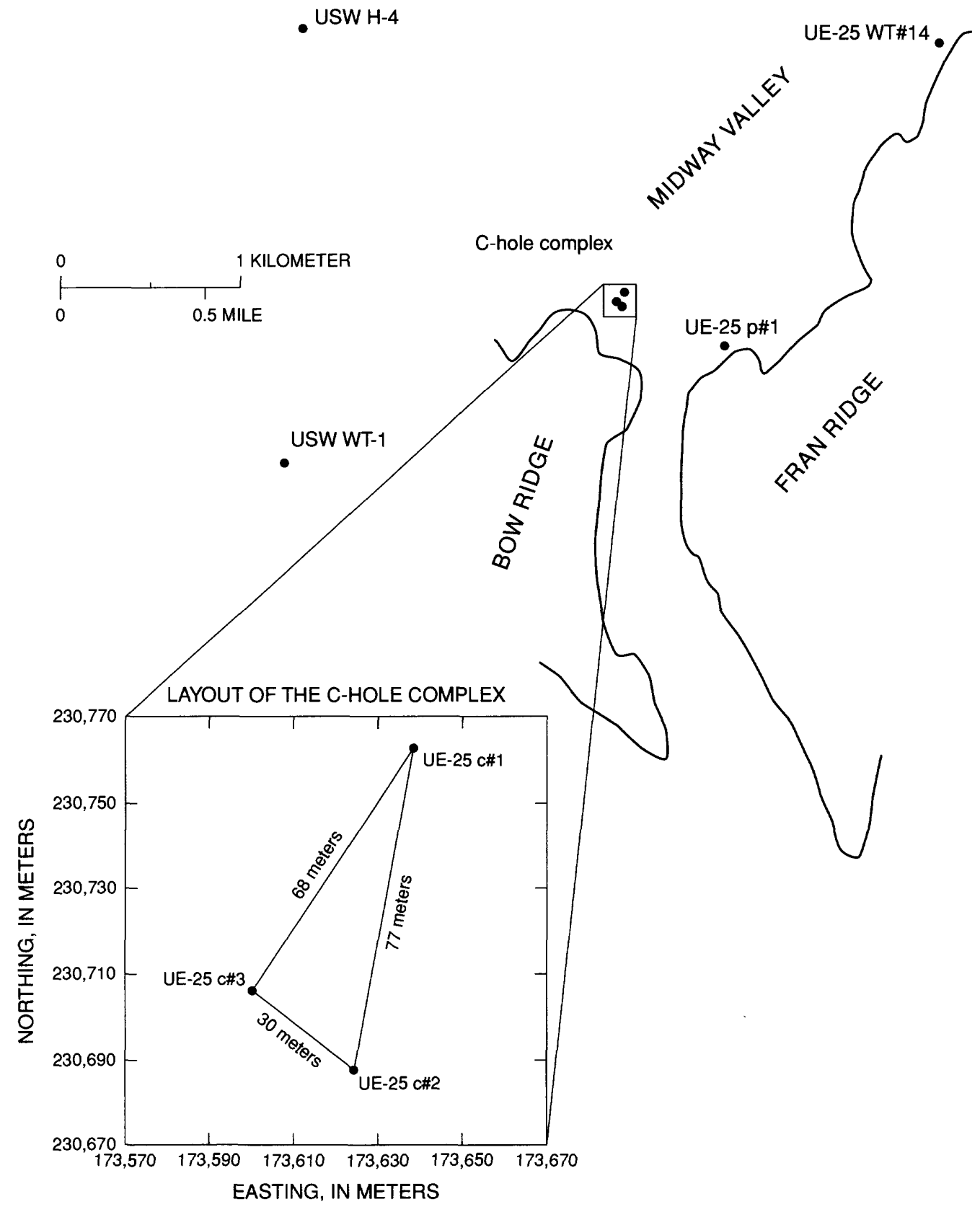

Figure 17. Layout of the C-hole complex. 


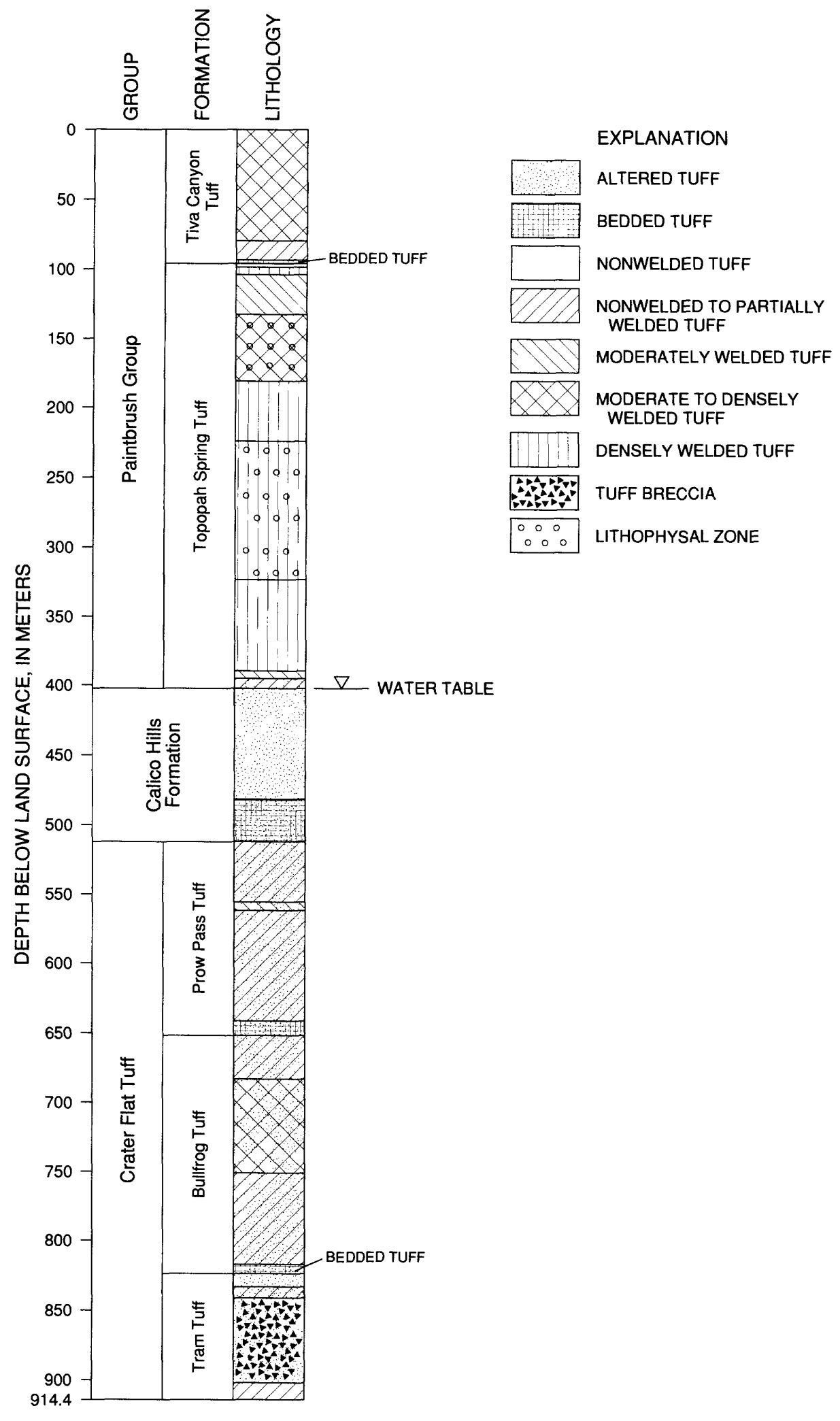

Figure 18. Stratigraphy and lithology at the C-hole complex (modified from Geldon, 1993, fig. 8). 
complex requires that this model be considered. Another reason that this conceptual model may not be appropriate is the probable presence of subvertical fractures that would create hydraulic connections between the major permeable zones. During hydraulic tests at the C-hole complex, each of the major permeable zones could be isolated by packers and pumped. If no response was detected in the nonpumped zones, then this model would be more plausible. In this case, the tests may be analyzed using several equivalentporous-medium layers.

The second conceptual model would treat the entire saturated thickness as an interconnected network of a limited number of fractures, fracture zones, and faults. In this model, subvertical fractures or the fault, or both, provide hydraulic connections between the fracture zones identified in the boreholes. If this model is correct, pumping from any one zone would create measurable drawdown in most or all other water-producing fracture zones. If this is an appropriate conceptual model, the hydraulic and tracer tests could be usedpif possible, to map all of the major connections and pathways. Analysis of hydraulic and tracer tests would then be much more complex and might require the application of fracture-network modeling techniques.

\section{DISCUSSION OF THE SATURATED ZONE AT YUCCA MOUNTAIN}

The flow system at Yucca Mountain occurs in a sequence of fractured volcanic rocks and underlying carbonate rocks. In this report, the volcanic sequence is divided into two aquifers (the upper and lower volcanic aquifers) and two confining units (the upper and lower volcanic confining units). The division does not correlate exactly with either the stratigraphic units or the thermal/mechanical units and is useful only as a general guideline as to where flow might occur. Generally, only a small number of intervals in the aquifers, usually associated with fractures or faults, produce water. The confining units also may transmit water, but to a lesser extent than the aquifers. In both the aquifers and the confining units, fractures probably transmit more water than the rock matrix does. The less transmissive units probably have a much larger proportion of their flow occurring in the matrix. The lower volcanic confining unit may transmit little water, primarily because lithostatic pressure keeps the fractures closed.

Little is known about the carbonate rocks beneath Yucca Mountain, but they constitute a major aquifer in the region. The carbonate aquifer probably underlies the lower volcanic confining unit beneath all of Yucca Mountain. Several lines of evidence indicate that the lower volcanic confining unit effectively isolates the carbonate aquifer from the volcanic aquifers. However, the altered mineralogy of the tuffs, particularly in borehole UE-25 p\#1, indicates past influx of deeper water, possibly localized along faults. Higher water-table temperatures aligned along existing faults may indicate upwelling, probably from the carbonate aquifer. Beneath the northern part of Yucca Mountain, the carbonate aquifer may additionally be confined by the Eleana Formation. If the volcanic aquifers are essentially isolated from the carbonate aquifer, then the potentiometric surface in the volcanic aquifer would be independent of the potentiometric surface in the carbonate aquifer. If, however, the confinement is breached by faults and, particularly if flow through one or the other aquifers is not large compared to upwelling or downwelling between aquifers, the potentiometric surface in one system may affect the potentiometric surface in the other system.

On a regional scale, flow is generally from the higher plateaus in the north to the Amargosa Desert in the south, probably continuing southward or westward, or both, to still lower areas of discharge. How flow moves through the Timber Mountain area is not clear because of lack of data. In the immediate vicinity of Yucca Mountain, the flow direction seems to be more eastward as indicated by the potentiometric contours, although anisotropy may deflect part of the flow southward. Whatever part of the flow that persists eastward to reach the Fortymile Wash area then would flow southward through the trough of the potentiometric surface.

In the area of small hydraulic gradient at Yucca Mountain, the potentiometric surface is a continuous, almost flat surface that does not change noticeably as it passes through the various faults east of the Solitario Canyon Fault. The potentiometric surface slopes gently to the east at a relatively constant gradient (fig. 9). However, because the transmissivity of the rocks probably is not isotropic, flow is not necessarily perpendicular to the contours. Flow may be more southerly because the major faults and fractures in the area 
tend to be north-trending and may divert flow to the south.

The potentiometric surface in the area of small hydraulic gradient also does not seem to change as it transects aquifers and confining units. Beneath the crest of Yucca Mountain, flow is entirely in the lower volcanic aquifer and deeper units. However, at Fortymile Wash, the upper volcanic aquifer dips beneath the water table and dominates the flow system. There is no obvious break in the slope of the potentiometric surface in the transition area, which must be somewhere in Midway Valley (fig. 9). In the vicinity of the large hydraulic gradient in the northern Yucca Mountain area, the potentiometric surface may or may not reflect a change in hydrogeologic units, depending on the interpretation of the cause of the large hydraulic gradient.

The volume of ground water that flows beneath Yucca Mountain is unknown. If the large hydraulic gradient to the north of Yucca Mountain and the moderate hydraulic gradient to the west of the crest of the mountain effectively isolate the volcanic flow system from the regional flow system and, if the lower volcanic confining unit effectively isolates the volcanic and carbonate flow systems from each other, little water could be moving beneath the mountain. If these barriers are not particularly effective, then ground-water flow beneath Yucca Mountain could be much greater. The small hydraulic gradient can be interpreted as an area of either high transmissivity or small groundwater flux (Ervin and others, 1993, p. 1558), or some combination of the two. Because there is no direct way to measure ground-water flow, resolution of the possible causes of the small hydraulic gradient would depend on both direct and indirect evidence. Sufficient testing to determine transmissivity and anisotropy on scales of tens to hundreds of meters, combined with measured hydraulic gradients (fig. 9), would allow a direct estimate of flow. Detailed hydrochemical characterization, combined with analysis of rock-water interaction and water-chemistry evolution, would provide indirect evidence of the rate of flow. Likewise, water ages estimated from isotopic data would provide indirect evidence. Understanding the inflows to the volcanic aquifers across the large and moderate hydraulic gradients and from the carbonate aquifer may influence judgments as to the amount of flow in the area of the small hydraulic gradient. However, there is no direct method to measure these inflows either.

\section{Conceptual Uncertainties}

Although the flow system at Yucca Mountain has been divided into a series of aquifers and confining units, and the general direction of flow is known, substantial conceptual uncertainties remain. Fractures probably transmit most of the water through the aquifers, but at individual boreholes, only a small percentage of the fractures contribute flow and faults frequently dominate the flow. Conceptually, flow in the saturated zone occurs predominately in a few fractures, but as a practical matter, numerical models would have to simulate the system either as a porousmedia continuum or as a finite number of discrete features. At the scale of the Yucca Mountain site, it is not yet known whether fractures are so pervasive that the flow system can be simulated as a classical porous medium or if discrete features need to be simulated.

The discussions about the large hydraulic gradient, and to a lesser extent the moderate hydraulic gradient under the "Potentiometric Surface" section, indicated that there is uncertainty about bow the flow system behaves in these areas. This uncertainty would translate into uncertainty about either external or internal boundary conditions when a numerical model is developed. The uncertainties about potential groundwater divides also would translate into uncertainty about the numerical-model boundary conditions.

Although recharge certainly is related to climate, topography, flora, soils, and unsaturated-zone flow, major uncertainties exist about the interrelation and this uncertainty translates into a general conceptual uncertainty about recharge. Perhaps equally important, the time scale at which the flow system comes into equilibrium with climate, and hence recharge, is a conceptual uncertainty.

Tests to determine flow-system parameters are conducted at scales that are much smaller than the scales that ultimately need to be simulated. How to translate data from a test scale to a model scale is a major conceptual uncertainty. It may not be clear even whether the test scale underestimates or overestimates the parameter required at the model scale.

\section{Data Uncertainties}

No matter how well the saturated-zone flow system at Yucca Mountain and vicinity is described, uncertainty will always remain. The data needed to 
simulate the ground-water flow system (in order according to the assumed uncertainty from largest to smallest) would be: (1) recharge; (2) storage properties; (3) transmissive properties; (4) discharge; and (5) hydraulic head. A discussion of each of these uncertainties follows.

\section{Recharge}

Recharge in arid environments is perhaps the most difficult model variable to quantify because: (1) the uncertainty in the relation between precipitation and resultant recharge; (2) the sporadic and infrequent nature of major precipitation events; and (3) the uncertainty in the location and distribution of subsurface barriers and conduits (such as fractures and faults) that could retard or enhance recharge. In various numerical models of the regional flow system (Oberlander, 1979; Waddell, 1982; Czarnecki and Waddell, 1984; Sinton, 1987; D'Agnese, 1994), recharge to the flow system was estimated and was assumed to be in equilibrium with discharge, a necessary but somewhat questionable, assumption.

Despite the difficulties and uncertainties, recharge was estimated in these studies based on where recharge was likely to occur (using topographic and climatic information) and where recharge was required by the model to make the model adequately simulate measured potentiometric levels. An example of the latter was recharge along Fortymile Wash. In the models developed by Czarnecki and Waddell (1984) and Sinton (1987), recharge had to be specified along Fortymile Wash for the models to accurately simulate measured potentiometric levels in the vicinity of Yucca Mountain.

In contrast, the northernmost boundary in the Czarnecki and Waddell (1984) model consisted of a series of constant-head nodes that supplied the appropriate amount of inflow across the boundary to make total inflow equal total outflow. This inflow simulated the throughflow of recharge from Pahute and Rainier Mesas, areas that are topographically higher and climatically wetter than Yucca Mountain. This northern boundary was set sufficiently distant from Yucca Mountain so the boundary would not overly affect simulated ground-water conditions at Yucca Mountain.

\section{Storage Properties}

Storage properties of the saturated-zone flow system at Yucca Mountain were not discussed in great detail in the "Aquifer Tests" section because so little data exist for storage properties. Estimates for storage properties are uncertain even when aquifer tests are conducted with nearby observation holes; storage properties are particularly unreliable for single-hole tests, which is the usual type for Yucca Mountain. Therefore, storage properties were estimated or assumed only for a few boreholes in the Yucca Mountain area, and these estimates were quite different from borehole to borehole.

Storage properties are not required for steadystate simulations of ground-water flow, but are required for time-dependent simulations and are critical in transport simulations. The range of values for storativity for water-table conditions (unconfined flow) may be large because effective porosity may be as small as 0.001 for fractured tuff and may exceed 0.20 for alluvium or nonwelded tuff. For confined flow or deep unconfined flow within the saturated zone, the storativity could be an order of magnitude or more smaller. This wide range of uncertainty about the value of storativity would then result in wide ranges of uncertainty in estimates of ground-water travel times and transport characteristics.

\section{Transmissive Properties}

Transmissivity or hydraulic conductivity estimates based on aquifer tests in boreholes are available from a variety of sources, which used a variety of methods for the Yucca Mountain area, but the analysis of the tests require assumptions that frequently cannot be demonstrated to be even approximately correct. The reliability of the commonly used slug tests for estimating values of transmissivity in fractured tuff at Yucca Mountain is suspect in many cases, in part because the testing could have caused either elastic fracture dilatation or fracture-deformation by hydraulic fracturing of the rock mass (Thordarson and others, 1985, p. 19; Stock and Healey, 1988). Additionally, the results of many of these slug tests could not be analyzed reliably because conditions in the boreholes were not appropriate for the porous-medium type of analysis required of slug tests.

The geometric mean value of the transmissivities listed in table 5 was about $70 \mathrm{~m}^{2} / \mathrm{d}$, but the range was from 1.5 to $3,250 \mathrm{~m}^{2} / \mathrm{d}$. Transmissivity probably 
varies considerably around Yucca Mountain, but part of the range in values probably is due to uncertainty in the estimates. There is uncertainty in how to interpret the results of individual aquifer tests. Craig and Reed (1991, p. 9-13) analyzed one aquifer test in borehole USW H-6 four different ways and got values of 240, 480,210 , and $370 \mathrm{~m}^{2} / \mathrm{d}$. They chose $240 \mathrm{~m}^{2} / \mathrm{d}$ as the most reasonable value. The need to rely principally on single-borehole tests is a major cause of uncertainty in estimating both transmissive and storage properties. As discussed in the "Aquifer Tests" section, Geldon (1996) concluded that single-borehole tests did not provide reliable estimates of large-scale transmissivity at the C-hole complex and yielded transmissivity values that were about 100 times smaller than multipleborehole tests. Unfortunately, the $\mathrm{C}$-hole complex is the only place at Yucca Mountain where multipleborehole tests can be conducted using existing boreholes.

Ground-water flow models have been used to estimate transmissivity over large areas. Waddell (1982), in his ground-water flow model of the Death Valley flow system, had two zones that included the Yucca Mountain area. Zone 1, which included the western and central part of the Yucca Mountain area, had an estimated transmissivity of about $700 \mathrm{~m}^{2} / \mathrm{d}$, whereas Zone 8, which included the eastern part of the Yucca Mountain area, had an estimated transmissivity of about $7 \mathrm{~m}^{2} / \mathrm{d}$. The zones were quite large, and the model was not intended to be used to estimate transmissivity at Yucca Mountain, so these values need to be used with discretion. Czarnecki and Waddell (1984) modeled the subbasin of the Death Valley flow system that includes Yucca Mountain. Their Zone 10, which included the western part of Yucca Mountain, had an estimated transmissivity of about $80 \mathrm{~m}^{2} / \mathrm{d}$, whereas Zone 6, which included the eastern part of Yucca Mountain, had an estimated transmissivity of more than $3,000 \mathrm{~m}^{2} / \mathrm{d}$. Transmissivity estimates from field tests and from simulations seem to be generally consistent, both in the order of magnitude of the values and the range in values. However, the field tests and simulations have a large uncertainty associated with them.

Vertical hydraulic conductivity and anisotropy are parameters that need to be incorporated into a three-dimensional flow model, but frequently are not simply because no data on them are available. Tests to estimate vertical hydraulic conductivity were conducted only at borehole USW H-5 (Robison and Craig, 1991, p. 26) and at the C-hole complex (Geldon, 1996). Data from borehole USW H-5 should be used with discretion because it may not be representative of the area. As was discussed in the "Potentiometric Surface" section, USW H-5 has a potentiometric level consistent with boreholes west of the Solitario Canyon Fault, even though the borehole is east of the fault. Anisotropy was estimated only for borehole USW H-4 (Erikson and Waddell, 1985, p. 24-29). These parameters are uncertain, both because of the few estimates available and because the estimates themselves are uncertain.

\section{Dlscharge}

Discharges at Alkali Flat and Furnace Creek Ranch (table 7) have been quantified on the basis of

Table 7. Estimates of ground-water discharge at Alkali Flat and Furnace Creek Ranch

\begin{tabular}{|c|c|c|}
\hline \multirow{2}{*}{ Reference } & \multicolumn{2}{|c|}{$\begin{array}{l}\text { Discharge, in millions of } \\
\text { cubic meters per year }\end{array}$} \\
\hline & Alkall Flat & $\begin{array}{c}\text { Furnace } \\
\text { Creek Ranch }\end{array}$ \\
\hline Walker and Eakin, 1963 (table 7) & $1<29$ & -- \\
\hline Pistrang and Kunkel, 1964 (table 4) & -- & 5.0 \\
\hline Hunt and others, 1966 (table 25) & -- & 6.3 \\
\hline Winograd and Thordarson, 1975; Waddell (1982, p. 17-18) & \multicolumn{2}{|c|}{$\begin{array}{l}\text { Summarized previous estimates; did not make new } \\
\text { estimates. }\end{array}$} \\
\hline Czarnecki and Waddell, 1984 (table 3) & 9.3 & 5.3 \\
\hline Czarnecki, 1990 (p. 78) & 8.3 & -- \\
\hline D'Agnese, 1994 (p. 298) & 6.3 & 4.1 \\
\hline
\end{tabular}


field observations or simulations by previous investigators (Walker and Eakin, 1963; Pistrang and Kunkel, 1964; Hunt and others, 1966; Winograd and Thordarson, 1975; Waddell, 1982; Czarnecki and Waddell, 1984; Czarnecki, 1990; D’Agnese, 1994). The uncertainty in the estimates of discharge was less than the uncertainty for the other variables needed to simulate ground-water flow in the vicinity of Yucca Mountain. However, the uncertainty in discharge may still be large enough to warrant further refinement, particularly if, as the numerical models are updated, flow at Yucca Mountain appears to be sensitive to this parameter. An important factor in estimating discharge will be determining the area over which evapotranspiration occurs at Alkali Flat (Franklin Lake Playa). In addition to the discharge at Alkali Flat and Furnace Creek Ranch, some flow could continue southward beyond Alkali Flat and enter Death Valley from the south.

Czarnecki and Wilson (1991) developed a conceptual model that excluded Furnace Creek Ranch as a discharge area for the shallow flow system that includes Yucca Mountain. They reported that sparse potentiometric data indicated that a ground-water divide could exist in the Greenwater Range between the southern Amargosa Desert and Death Valley. Potentiometric levels beneath the Greenwater Range were as much as $875 \mathrm{~m}$ above sea level, whereas potentiometric levels in the Amargosa Desert were about $620 \mathrm{~m}$ above sea level and were at or below sea level at the floor of Death Valley. The nearby Funeral Mountains are higher than the Greenwater Range, receive more precipitation, and may have a similar ground-water divide (Czarnecki and Wilson, 1991, p. 22). Such a divide, if it extends farther north beneath the southern Funeral Mountains, could limit discharge from the shallow flow system in the Amargosa Desert to the Furnace Creek Ranch area. Such a divide, if it does exist, would not necessarily affect the deeper flow system that also may contribute discharge to the Furnace Creek Ranch area.

\section{Potentiometric Levels}

Potentiometric levels are the most numerous and the easiest of the model variables to obtain. Numerous boreholes where potentiometric levels can be measured are located throughout the flow system, although most are clustered in the vicinity of Yucca Mountain and in the Amargosa Desert. Uncertainty in potentiometric levels is small where data are common, but can be large where data are sparse. Although values of potentiometric levels obtained from field measurements probably are accurate only to within a few meters of true values in many areas, the accuracy of measured potentiometric levels at Yucca Mountain is about $0.11 \mathrm{~m}$ (Boucher, 1994b, p. 17). The accuracy of measured potentiometric levels can be somewhat offset by the manner in which these data are used as a calibration standard for numerical models. The error associated with comparing measured potentiometric levels to model estimates can be larger than the measurement error because of the spatial distance between the field and model points. Where numerous boreholes are clustered in an area, an average value of the potentiometric level frequently is calculated and compared against the model node that represents the area. The potentiometric level measured in some boreholes may represent a composite level from multiple hydrogeologic units. Composite levels are frequently difficult to interpret and may be difficult to use as a calibration standard.

The differences between measured potentiometric levels and those calculated using a model need to be considered in the context of the range of potentiometric levels in the part of the flow system where the level is being calculated. In the area of the large hydraulic gradient at Yucca Mountain, potentiometric levels change $300 \mathrm{~m}$ in just a few kilometers; a small difference between measured and calculated potentiometric levels in this area would be insignificant. However, in the area of the small hydraulic gradient, where potentiometric levels change less than $1 \mathrm{~m}$ over several kilometers, small differences between measured and calculated potentiometric levels would be important.

Little is known about the distribution of potentiometric levels with depth within the flow system. Potentiometric levels have been measured at various depths in only a few boreholes, and these boreholes were generally concentrated around Yucca Mountain. Potentiometric-level data in the vertical dimension may be critical for calibrating three-dimensional ground-water flow models.

\section{Proposed Simulations}

This report has discussed various alternative concepts or components of conceptual models of the saturated-zone flow system at Yucca Mountain. This 
section discusses some of the more important alternate concepts about the flow system that can be addressed, at least in part, with the numerical models of the flow system. The "Additional Data Needs" section discusses field investigations needed to adequately characterize the saturated-zone flow system. Some hypotheses and interpretations may quickly prove untenable during numerical simulation and may not need additional data. For those hypotheses that cannot be eliminated through numerical simulation, field investigations may be necessary to choose between alternative hypotheses.

\section{Discrete Features}

The degree to which faults and fractures dominate large-scale permeability in the flow system at the scale of Yucca Mountain is important to predictions of ground-water travel times and radionuclide transport. At individual boreholes, most water production comes from a few fractures. Where fault zones are present in boreholes, these zones frequently produce much of the water. This does not mean that all faults produce water, but rather that, when faults are present, much of the production seems to come from the faults. On the scale of Yucca Mountain, the potentiometric surface appears fairly smooth and water chemistry seems relatively consistent and does not vary dramatically over short distances. The borehole-scale and the site-scale observations result in conflicting information about the importance of faults to the ground-water flow system. Existing numerical flow models at the regional and subregional scales have been developed assuming that faults and fractures are so pervasive in the area that, at the scale simulated, the flow system can be modeled using a classical porous-medium approach. These regional and subregional flow models have been successful in duplicating the large-scale behavior of the flow system. Barr and others (Wilson and others, 1994, chapter 11) constructed a site-scale flow model to do performance-assessment calculations that explicitly accounted for the Solitario Canyon Fault and the Drillhole Wash Fault. Constant-head boundary conditions were assigned around the entire boundary. Such boundary conditions are reasonable for doing performance-assessment calculations, but may have made the model too insensitive to internal conditions to adequately investigate the effect of the faults. Therefore, at the scale of Yucca Mountain, it is not clear whether individual faults and fracture zones will predominate the flow system or if the flow system will behave approximately as an extensive porous medium.

Investigations as to whether the system can be treated as an equivalent porous medium or if discrete features need to be accounted for can best be carried out using a series of numerical simulations. The best simulation of the flow system as a continuous porous medium would be the baseline case for the investigation. The baseline case would not necessarily be either a homogeneous or an isotropic simulation. The first alternative case would treat the major faults and fracture systems as interconnected drains of different characteristics that carry most of the flow. Flow in the first alternative case would be analogous to flow through a series of interconnected parallel plates; the hydraulic characteristics of the faults and fracture systems would be varied according to their orientation, type, and other characteristics. If the first alternative case could reasonably reproduce known features of the flow system, subsequent simulations could reduce the number of faults and fracture systems that actively participate in the flow system, until the simulation no longer reasonably reproduces the important features of the flow system. A second alternative case would treat the flow system as a porous medium in which a few important faults and fracture systems are treated discretely. The base case and the alternative cases would be compared to determine the degree to which discrete features dominate the site-scale flow system.

\section{Hydraulic Gradients}

While awaiting new field data to characterize the large hydraulic gradient, simulations could be used to test whether any of the hypotheses related to the cause of the large hydraulic gradient can be discarded based on existing data. Simulations could investigate whether or not the upper volcanic confining unit could be enough of a hydraulic barrier to support the large hydraulic gradient. Simulations also could test if the drain hypothesis or the semiperched hypothesis discussed in the "Large Hydraulic Gradient" section are consistent with the existing data set. Given the large uncertainty in parameters, boundary conditions, and geometry of hydrogeologic units north of Yucca Mountain, the existing data set may not rule out any of these hypotheses. However, the simulations might provide the basis for discarding hypotheses once new field data are available. The simulations also may 
guide further data collection for the characterization of the large hydraulic gradient.

Simulations also could be made to determine if the Solitario Canyon Fault associated with the moderate hydraulic gradient should be treated as a no-flow boundary for the Yucca Mountain flow system or if it needs to be treated as a leaky boundary. Such simulations could be used to make predictions about the results of the proposed Solitario Canyon Fault test (U.S. Department of Energy, 1990a, sec. 3.1) in the moderate hydraulic gradient area. The simulations, when combined with field investigations, could provide the basis for accepting the fault as a no-flow boundary, a leaky boundary, or a hydrologically transparent feature.

Numerical models can be used to test the relative sensitivity of the flow system to changes in inflows and outflows that might result from climatic or tectonic changes. Because most of the inflow to the flow system at Yucca Mountain is through the upper volcanic confining unit or the lower volcanic aquifer, both of which are poorly to moderately permeable, and most of the outflow is through the upper volcanic aquifer, which seems to be highly permeable, the flow system could be inflow limited. "Inflow limited" means that water can leave the flow system more easily than it can enter the flow system and that the outflow part of the system possibly could accommodate a much larger change in flow with a smaller change in potentiometric level than could the inflow part. Czarnecki (1985, p. 20-27) probably experienced an inflow-limited condition when he simulated the effects of a 100-percent increase in precipitation in the recharge areas for the Yucca Mountain flow system. The simulation indicated that upper Fortymile Wash would become a perennial stream and the northern model boundary would reject some potential inflow because increased recharge from precipitation could not enter the ground-water flow system. Tectonic or climate changes would have less effect on an inflowlimited saturated-zone flow system because any additional water entering the flow system could easily leave the system, and water levels beneath Yucca Mountain would change much less than they would to the north of the mountain.

\section{Climate and Recharge}

Regional modeling of the Yucca Mountain flow system has assumed that the system is in steady state, that is, in equilibrium with the modern climate. However, some investigators (Winograd and Doty, 1980; Claassen, 1985) have suggested that recharge in the Yucca Mountain region has occurred mainly during pluvial cycles and the system is not in steady state. The assumption of equilibrium conditions can be investigated using numerical simulations. A simulation could be made that begins with potentiometric levels in the system at least as high as permitted by any reasonable data or analyses. The flow system then would be allowed to drain, without additional recharge, to determine if the modern flow system could simply be a relic of a flow system that was filled to capacity during the last glacial period. This simulation would be similar to one done by Luckey and others (1986, p. 11) for the southern High Plains. The simulation probably would assume that Fortymile Wash and some of the washes in Crater Flat were perennial streams that drained the flow system when it was filled to capacity. Initial potentiometric levels in this simulation could be as much as several hundred meters above the modern water table. If the flow system drains significantly below modern potentiometric levels in only a few millennia, this simulation would indicate that the modern flow system is not simply a relic of glacial-period recharge because the apparent age of the water is older than a few millennia (Benson and others, 1983, table 1). The simulation then would be modified to include some post-glacial recharge until the flow system was reasonably simulated. If the flow system could be reasonably depicted, these simulations could yield information about the relative importance of glacial and post-glacial recharge.

A different approach to determine if the groundwater flow system were in equilibrium with the postglacial climate would involve a series of simulations in which, at episodic intervals, major flooding in Fortymile Wash added large quantities of recharge to the flow system and, between these intervals, the flow system drained. As an extreme case in these simulations, the large hydraulic gradient and the Solitario Canyon Fault could be assumed to be no-flow boundaries. This assumption would cause the ground-water flow system at Yucca Mountain to be effectively isolated and would allow the flow system to drain more quickly. Simulations could be made for floods with recurrence intervals of perhaps 500 or 1,000 years (or longer). Squires and Young (1984) estimated various characteristics of peak flow for 100-year, 500-year, and maximum regional floods for several sections of 
Fortymile Wash. However, estimating the volumes of such rare floods, as well as the recharge associated with them would be difficult. Therefore, although such simulations may provide useful insights, they probably would not provide definitive results because of the major unsubstantiated assumptions that need to be made.

\section{Additional Data Needs}

The "Proposed Simulations" section indicated that additional data are needed to resolve various questions about the saturated-zone ground-water flow system at Yucca Mountain. This section will be more specific about data that need to be collected to resolve some of the most important questions. The data needs that are discussed could improve the saturated-zone flow model and its application to performanceassessment issues, such as ground-water travel time, contaminant transport, and contaminant mixing or dilution.

Additional data are needed to resolve the cause of the large hydraulic gradient, the understanding of which could substantially alter the conceptual model of the saturated-zone flow system at Yucca Mountain. Proposed boreholes USW WT-23 and USW WT-24 (U.S. Department of Energy, 1990a, p. 3.2-7 to 3.2-9) could further define the extent and shape of the large hydraulic gradient. More recent proposals include drilling these two boreholes through the upper confining unit and into the lower volcanic aquifer to test if the semiperched explanation for the large hydraulic gradient is viable (TRW Environmental Safety Systems Inc., written commun., 1993, as documented in "Catalog of Planned Boreholes for Surface-Based Testing Site Characterization Activities," Rev. 0, p. 167). If proposed borehole USW G-5 (TRW Environmental Safety Systems Inc., written commun., 1993 , p. 137) penetrates into the carbonate aquifer, it may provide information on the drain theory developed by Fridrich and others (1994).

Logging and testing of existing borehole USW G-2 would provide inexpensive, but potentially valuable information about the large hydraulic gradient. This borehole penetrated the upper volcanic confining unit and the lower volcanic aquifer and reached total depth in the lower volcanic confining unit. Previous information indicated that this borehole produced no water from the lower volcanic aquifer (fig. 15).
This lack of production needs to be replicated by pumping discrete intervals of the borehole. Hydrochemical samples need to be obtained when pumping is done to determine the source of water to the various intervals of the borehole.

If future drilling indicates that flow in the saturated zone through or beneath the large hydraulic gradient is large, additional drilling to provide potentiometric level data north of Yucca Mountain may be needed. The drilling would not only better define the potentiometric surface to the north, but it also would help define the nature of the northern boundary of the Yucca Mountain flow system. The drilling might provide insight as to how the northern boundary condition might change in response to future climatic or tectonic conditions.

The cause of the moderate hydraulic gradient to the west of Yucca Mountain needs to be resolved. Results of the Solitario Canyon Fault study (U.S. Department of Energy, 1990a, sec. 3.1) possibly would resolve the issue. Three additional boreholes are proposed for that study and a long-term hydraulic test is proposed to determine the hydrologic importance of the fault. The test also may contribute to understanding the hydrologic nature of other nearby faults.

Tests at the C-hole complex (U.S. Department of Energy, 1990a, sec. 3.4 and 3.5) would determine the hydraulic and transport properties at this site. The $\mathrm{C}$-hole complex is the only site at which the borehole configuration allows the critical transport parameter, effective porosity, to be measured. Data from this site also may help resolve the issue of anisotropy. Additional data about hydraulic and transport properties certainly will be needed elsewhere; how to collect such data most efficiently could be one of the most important results of tests at the $\mathrm{C}$-hole complex. The work at the $\mathrm{C}$-hole complex needs to be followed by studies at additional multihole sites.

A detailed hydrochemical characterization of the saturated zone as described by the U.S. Department of Energy (1992a) could refine the conceptual model of flow at Yucca Mountain and could provide data that will help in the calibration of the numerical model.

The frequency and amount of recharge that occurs in Fortymile Wash warrants further study. Savard (1994) documented that runoff in upper Fortymile Wash caused an almost immediate rise in water levels in nearby boreholes. Results of this study 
could help constrain the simulations of recharge in Fortymile Wash that were discussed in the "Climate and Recharge" section.

More definitive information is needed about the hydrologic effects of wetter and cooler climates in the recent geologic past. The deposits discussed in the "Northern Discharge Deposits" section may provide important data for calibrating a numerical flow model. The modern depth to water beneath the northern discharge deposits needs to be determined. The possibility that some local geologic structure caused the water table to rise to the land surface during wetter periods of the recent geologic past also could be investigated.

The relation of precipitation to recharge needs to be better understood so that the effects of climate changes can be realistically simulated. Total recharge is frequently estimated from total discharge, and it is generally distributed based on either precipitation and altitude or plant communities. Such a relation may not be appropriate under different climatic scenarios.

Unless the carbonate aquifer is demonstrated not to have a major effect on the volcanic flow system at Yucca Mountain, much more information is needed about the extent of this aquifer in the vicinity of the mountain. If the carbonate aquifer potentially has a major effect on flow in the volcanic aquifers, the hydrologic properties of the carbonate aquifer need to be determined. This need for data could be particularly expensive because the carbonate aquifer probably is quite deep under much of the Yucca Mountain area.

The development and calibration of a numerical model may indicate further data needs that were not anticipated in this report. Conversely, sensitivity analysis using a numerical model could indicate that some of the data needs described in this report do not greatly affect the numerical flow model; in which case, the data would not need to be collected.

\section{SUMMARY}

The area around Yucca Mountain in southern Nevada is being studied to determine if the site is suitable for permanent disposal of high-level radioactive waste in a geologic repository. The study of the hydrology of any potential geologic repository site is important because ground water is the primary medium for most radionuclides to move away from a geologic repository. This report summarizes the understanding of the saturated-zone flow system at Yucca Mountain as of 1995.

Yucca Mountain consists of a thick sequence of Tertiary volcanic rocks that are underlain, at least to the southeast, by Paleozoic carbonate rocks. Stratigraphic units important to the saturated-zone hydrology of the area include the Topopah Spring Tuff; the Calico Hills Formation; the Crater Flat Group; the Lithic Ridge Tuff; older tuffs, flows, and lavas beneath the Lithic Ridge Tuff; and Paleozoic rocks, particularly the carbonate aquifer. The alluvium, the Rainier Mesa Tuff, and the upper units of the Paintbrush Group are above the water table in the Yucca Mountain area, and only the lowermost member of the Paintbrush Group, the Topopah Spring Tuff, is beneath the water table, and then only in selected areas. Saturated-zone flow usually occurs in the Calico Hills Formation and in lower units because of the generally great depths to the water table.

The saturated-zone ground-water flow system at Yucca Mountain is part of the Alkali Flat-Furnace Creek subbasin of the Death Valley ground-water flow system. This subbasin is recharged in the higher mesas north of Yucca Mountain and discharges most of its water at Alkali Flat (Franklin Lake Playa). In this subbasin, water moves generally from north to south.

The geologic section at Yucca Mountain is divided for hydrologic purposes into three aquifers and two confining units. The upper volcanic aquifer consists of the densely welded section of the Topopah Spring Tuff. It is generally saturated only to the west, south, and east of Yucca Mountain. The upper volcanic confining unit consists of the lower part of the Topopah Spring Tuff, the Calico Hills Formation, and the uppermost part of the Crater Flat Group. The lower volcanic aquifer consists of most of the Crater Flat Group. The lower volcanic confining unit consists of the Lithic Ridge Tuff and older tuffs, flow breccia, and lavas beneath the Crater Flat Group. Paleozoic argillites may exist beneath the volcanic rocks beneath Yucca Mountain and may effectively thicken the lower volcanic confining unit. Beneath the volcanic aquifers and confining units is the carbonate aquifer, which consists mainly of Paleozoic limestones and dolomites.

The potentiometric surface in the Yucca Mountain area can be divided into the three general areas: (1) The area at the northern end of Yucca Mountain, where potentiometric levels exceed $1,000 \mathrm{~m}$ above sea 
level; (2) the area generally west of Solitario Canyon, where potentiometric levels are about $775 \mathrm{~m}$ above sea level; and (3) the area at Yucca Mountain and to the south and east, where potentiometric levels are about $730 \mathrm{~m}$ above sea level. The boundary between the first and third areas contains a large lateral hydraulic gradient over which potentiometric levels changed more than $260 \mathrm{~m}$ in less than $3 \mathrm{~km}$. The boundary between the second and third areas contains a moderate hydraulic gradient over which potentiometric levels changed about $45 \mathrm{~m}$ in 1 to $2 \mathrm{~km}$. The third area is characterized by a small hydraulic gradient; potentiometric levels changed only about 2 m over several kilometers.

Potentiometric levels in boreholes around Yucca Mountain generally change little with depth or potentiometric levels indicate a general upward gradient. Large vertical hydraulic gradients were measured only in a few boreholes. The largest differences in potentiometric levels, within the depths of exploration, were about $55 \mathrm{~m}$ at borehole USW $\mathrm{H}-1,22 \mathrm{~m}$ at borehole USW H-3, and $21 \mathrm{~m}$ at borehole UE-25 p\#1.

Limited hydraulic testing of boreholes in the Yucca Mountain area was done in the early 1980's. These tests were generally single-borehole tests and frequently tested large intervals of a borehole. Reported transmissivity values ranged over two or three orders of magnitudes within a particular hydrogeologic unit and the average values between hydrogeologic units generally differed by about an order of magnitude (table 5). The upper volcanic aquifer probably is the most permeable hydrogeologic unit, but this conclusion is based on exceedingly limited data.

Major sources of inflow to the hydrologic system at Yucca Mountain include upgradient inflows and recharge from Fortymile Wash, a major ephemeral surface drainage on the east side of Yucca Mountain. However, there is considerable uncertainty as to the magnitude of inflows from the northern and the western upgradient areas. Major sources of outflow from the hydrologic system are downgradient outflow and pumpage. Although some estimates have been made, the inflows and outflows are not well quantified.

Construction of numerical models would enable testing of various concepts about the saturated-zone flow system at Yucca Mountain; for example, the relative importance of major faults and fracture systems on the flow system, whether the flow system is in equilibrium with modern climate, and the various theories about the cause of the large hydraulic gradient.
Numerical models may have large uncertainties because of the complexity of the flow system at Yucca Mountain and insufficient data. The most important uncertainties among the numerical model components will be recharge, storage properties, hydraulic properties, discharge, and hydraulic head. To adequately understand the flow system at Yucca Mountain, additional data needs to be collected to resolve critical issues. The cause of the large hydraulic gradient is identified in this report to be a major issue that needs to be resolved. The cause of the moderate hydraulic gradient also needs to be resolved. The tests described to resolve the moderate-gradient issue could yield information on the importance of faults in the flow system. The proposed tests at the $\mathrm{C}$-hole complex may determine hydraulic, storage, and transport properties at this site. Additional data about these properties are needed at other sites at Yucca Mountain. The proposed hydrochemical characterization could provide additional information that could help calibrate the numerical model. Once the numerical model is developed and calibrated, a sensitivity analysis could indicate other data needs and might indicate that some of the data are not critical.

\section{SELECTED REFERENCES}

Ahola, M.P., and Sagar, Budhi, 1992, Regional groundwater modeling of the saturated zone in the vicinity of Yucca Mountain, Nevada: U.S. Nuclear Regulatory Commission Report NUREG/CR-5890, 47 p.

-1993, Modeling of saturated zone at Yucca Mountain, Nevada, in High Level Radioactive Waste Management, Proceedings of the Fourth Annual Internationa] Conference, Las Vegas, Nevada, April 26-30, 1993:

La Grange Park, Ill., American Nuclear Society, p. 1602-1608.

Anderson, L.A., 1981, Rock property analysis of core samples from the Yucca Mountain UE25a-1 borehole, Nevada Test Site, Nevada: U.S. Geological Survey Open-File Report 81-133, 36 p.

Barr, G.E., 1985, Reduction of the well test data for test well USW H-1, adjacent to Nevada Test Site, Nye County, Nevada: Albuquerque, N.M., Sandia National Laboratories Report SAND84-0637, 41 p. 1991, Reduction of the well test data for test wel] USW G-4, Yucca Mountain, Nye County, Nevada: Albuquerque, N.M., Sandia National Laboratories Report SAND88-0265, 55 p. 
Barr, G.E., and Miller, W.B., 1987, Simple models of the saturated zone at Yucca Mountain: Albuquerque, N.M., Sandia National Laboratories Report SAND87-0112, 84 p.

Barr, G.E., and Shannon, S.A., 1994, Constraining local 3-D models of the saturated zone, Yucca Mountain, Nevada, in High Level Radioactive Waste Management, Proceedings of the Fifth Annual International Conference, Las Vegas, Nevada, May 22-26, 1994: La Grange Park, Ill., American Nuclear Society, p. 1814-1821.

Bath, G.D., and Jahren, C.E., 1984, Interpretations of magnetic anomalies at a potential repository site located in the Yucca Mountain area, Nevada Test Site: U.S. Geological Survey Open-File Report 84-120, 40 p.

Bedinger, M.S., Sargent, K.A., and Langer, W.H., eds., 1989, Studies of geology and hydrology in the Basin and Range province, southwestern United States, for isolation of high-level radioactive waste-Characterization of the Death Valley region, Nevada and California: U.S. Geological Survey Professional Paper 1370-F, 49 p.

Bedinger, M.S., Sargent, K.A., Langer, W.H., Sherman, F.B., Reed, J.E., and Brady, B.T., 1989, Studies of geology and hydrology in the Basin and Range province, southwestern United States, for isolation of high-level radioactive waste-Basis for characterization and evaluation: U.S. Geological Survey Professional Paper 1370-A, 41 p.

Bedinger, M.S., Sargent, K.A., and Reed, J.E., 1984, Geologic and hydrologic characterization and evaluation of the Basin and Range province relative to the disposal of high-level radioactive waste-Part I, introduction and guidelines: U.S. Geological Survey Circular 904-A, 16 p.

Benson, L.V., and McKinley, P.W., 1985, Chemical composition of ground water in the Yucca Mountain area, Nevada, 1971-84: U.S. Geological Survey Open-File Report 85-484, 10 p.

Benson, L.V., Robison, J.H., Blankennagel, R.K., and Ogard, A.E., 1983, Chemical composition of ground water and the locations of permeable zones in the Yucca Mountain area, Nevada: U.S. Geological Survey Open-File Report 83-854, 19 p.

Bentley, C.B., 1984, Geohydrologic data for test well USW G-4, Yucca Mountain area, Nye County, Nevada: U.S. Geological Survey Open-File Report 84-063, $48 \mathrm{p}$.

Bentley, C.B., Robison, J.H., and Spengler, R.W., 1983, Geohydrologic data for test well USW H-5, Yucca Mountain area, Nye County, Nevada: U.S. Geological Survey Open-File Report 83-853, 34 p.

Bish, D.L., Caporuscio, F.A., Copp, J.F., Crowe, B.M., Purson, J.D., Smyth, J.R., and Warren, R.G., 1981,
Preliminary stratigraphic and petrologic characterization of core samples from USW G-1, Yucca Mountain, Nevada: Los Alamos, N.M., Los Alamos National Laboratory Report LA-8840-MS, 66 p.

Blankennagel, R.K., 1967, Hydraulic testing techniques of deep drill holes at Pahute Mesa, Nevada Test Site: U.S. Geological Survey Open-File Report, 50 p. [Interagency report: Special studies I-1]

Blankennagel, R.K., and Weir, J.E., Jr., 1973, Geohydrology of the eastern part of Pahute Mesa, Nevada Test Site, Nye County, Nevada: U.S. Geological Survey Professional Paper 712-B, 35 p.

Bodvarsson, Gudmundur, Chen, Gang, and Wittwer, Caroline, 1994, Preliminary analysis of threedimensional moisture flow within Yucca Mountain, Nevada, in High Level Radioactive Waste Management, Proceedings of the Fifth Annual International Conference, Las Vegas, Nevada, May 22-26, 1994: La Grange Park, Ill., American Nuclear Society, p. 2038-2047.

Boucher, M.S., 1994a, Water levels in wells J-11 and J-12, Yucca Mountain area, Nevada: U.S. Geological Survey Open-File Report 94-303, 9 p.

1994b, Precision and accuracy of manual water-level measurements taken in the Yucca Mountain area, Nye County, Nevada, 1988-90: U.S. Geological Survey Water-Resources Investigations Report 93-4025, 18 p.

Bredehoeft, J.D., England, A.W., Stewart, D.B., Trask, N.J., and Winograd, I.J., 1978, Geological disposal of highlevel radioactive wastes-Earth-science perspectives: U.S. Geological Survey Circular 779, 15 p.

Brocher, T.M., Carr, M.D., Fox, K.F., Jr., and Hart, P.E., 1993, Seismic reflection profiling across Tertiary extensional structures in the eastern Amargosa Desert, southern Nevada, Basin and Range province: Geological Society of America Bulletin, v. 105, no. 1, p. 30-46.

Brocher, T.M., Hart, P.E., Hunter, C.E., and Langenheim, V.E., 1996, Hybrid-source seismic reflection profiling across Yucca Mountain, Nevada-Regional lines 2 and 3: U.S. Geological Survey Open-File Report 96-28, 110 p.

Broxton, D.E., Bish, D.L., and Warren, R.G., 1987, Distribution and chemistry of diagenetic minerals at Yucca Mountain, Nye County, Nevada: Clays and Clay Minerals, v. 35, no. 2, p. 89-110.

Buscheck, T.A., and Nitao, J.J., 1992, The impact of thermal loading on repository performance at Yucca Mountain in High Level Radioactive Waste Management, Proceedings of the Third Annual International Conference, Las Vegas, Nevada, April 12-16, 1992: La Grange Park, Ill., American Nuclear Society, p. 1003-1017. 
-1993, The analysis of repository-heat-driven hydrothermal flow at Yucca Mountain in High Level Radioactive Waste Management, Proceedings of the Fourth Annual International Conference, Las Vegas, Nevada, April 26-30, 1993: La Grange Park, Ill., American Nuclear Society, p. 847-867.

1995, Thermal-hydrological analysis of large-scale thermal tests in the Exploratory Studies Facility at Yucca Mountain: Livermore, Calif., Lawrence Livermore National Laboratory Report UCRL-ID-121791, $54 \mathrm{p}$.

Byers, F.M., Jr., Carr, W.J., Orkild, P.P., Quinlivan, W.D., and Sargent, K.A., 1976, Volcanic suites and related cauldrons of Timber Mountain-Oasis Valley caldera complex, southern Nevada: U.S. Geological Survey Professional Paper 919, 70 p.

Carlos, B.A., 1985, Minerals in fractures of the unsaturated zone from drill core USW G-4, Yucca Mountain, Nye County, Nevada: Los Alamos, N.M., Los Alamos National Laboratory Report LA-10415-MS, 55 p.

Carr, M.D., and Monsen, S.A., 1988, A field trip guide to the geology of Bare Mountain, in Weide, D.L., and Faber, M.L., eds., This extended land, Geological journeys in the southern Basin and Range: Las Vegas, University of Nevada at Las Vegas, Geological Society of America, Cordilleran Section, Field Trip Guide Book, p. 50-57.

Carr, M.D., Waddell, S.J., Vick, G.S., Stock, J.M., Monsen, S.A., Harris, A.G., Cork, B.W., and Byers, F.M., Jr., 1986, Geology of drill hole UE-25p \#1-A test hole into pre-Tertiary rocks near Yucca Mountain, southern Nevada: U.S. Geological Survey Open-File Report 86-175, 87 p.

Carr, M.D., and Yount, J.C., eds., 1988, Geologic and hydrologic investigations of a potential nuclear waste disposal site at Yucca Mountain, southern Nevada: U.S. Geological Survey Bulletin 1790, 152 p.

Carr, W.J., 1974, Summary of tectonic and structural evidence for stress orientation at the Nevada Test Site: U.S. Geological Survey Open-File Report 74-176, $53 \mathrm{p}$.

-1982, Volcano-tectonic history of Crater Flat, southwestern Nevada, as suggested by new evidence from drill hole USW VH-1 and vicinity: U.S. Geological Survey Open-File Report 82-457, 23 p.

- 1984, Regional structural setting of Yucca Mountain, southwestern Nevada, and late Cenozoic rates of tectonic activity in part of the southwestern Great Basin, Nevada and California: U.S. Geological Survey OpenFile Report 84-854, 109 p.

1988, Volcano-tectonic setting of Yucca Mountain and Crater Flat, southwestern Nevada, in Carr, M.D., and Yount, J.C., eds., Geologic and hydrologic investigations of a potential nuclear waste disposal site at Yucca
Mountain, southern Nevada: U.S. Geological Survey Bulletin 1790, p. 35-49.

-1990, Styles of extension in the Nevada Test Site region, southern Walker Lane Belt-An integration of volcano-tectonic and detachment fault models, in Wernicke, B.P., ed., Basin and range extensional tectonics near the latitude of Las Vegas, Nevada: Boulder, Colo., Geological Society of America, Memoir 176, chap. 13, p. 283-303.

Carr, W.J., Byers, F.M., Jr., and Orkild, P.P., 1986, Stratigraphic and volcano-tectonic relations of Crater Flat Tuff and some older volcanic units, Nye County, Nevada: U.S. Geological Survey Professional Paper 1323, $28 \mathrm{p}$.

Carr, W.J., Grow, J.A., and Keller, S.M., 1995, Lithologic and geophysical logs of drill holes Felderhoff Federal 5-1 and 25-1, Amargosa Desert, Nye County, Nevada: U.S. Geological Survey Open-File Report 95-155, $14 \mathrm{p}$.

Carr, W.J., and Parrish, L.D., 1985, Geology of drill hole USW VH-2, and structure of Crater Flat, southwestern Nevada: U.S. Geological Survey Open-File Report $85-475,41 \mathrm{p}$.

Carrigan, C.R., King, G.C.P., Barr, G.E., and Bixler, N.E., 1991, Potential for water-table excursions induced by seismic events at Yucca Mountain, Nevada: Geology, v. 19 , no. 12 , p. 1157-1160.

Ciesnik, M.S., 1995, Ground-water altitudes and well data, Nye County, Nevada, and Inyo County, California: U.S. Geological Survey Open-File Report 93-89, 27 p.

Claassen, H.C., 1985, Sources and mechanisms of recharge for ground water in the west-central Amargosa Desert, Nevada-A geochemical interpretation: U.S. Geological Survey Professional Paper 712-F, 31 p.

Craig, R.W., and Johnson, K.A., 1984, Geohydrologic data for test well UE-25p \#1, Yucca Mountain area, Nye County, Nevada: U.S. Geological Survey Open-File Report 84-450, 63 p.

Craig, R.W., and Reed, R.L., 1991, Geohydrology of rocks penetrated by test well USW H-6, Yucca Mountain, Nye County, Nevada: U.S. Geological Survey WaterResources Investigations Report 89-4025, 40 p.

Craig, R.W., Reed, R.L., and Spengler, R.W., 1983, Geohydrologic data for test well USW H-6, Yucca Mountain area, Nye County, Nevada: U.S. Geological Survey Open-File Report 83-856, 35 p.

Craig, R.W., and Robison, J.H., 1984, Geohydrology of rocks penetrated by test well UE-25p \#1, Yucca Mountain area, Nye County, Nevada: U.S. Geological Survey Water-Resources Investigations Report 84-4248, $57 \mathrm{p}$. 
Czarnecki, J.B., 1985, Simulated effects of increased recharge on the ground-water flow system of Yucca Mountain and vicinity, Nevada-California: U.S. Geological Survey Water-Resources Investigations Report 84-4344, 33 p.

1989a, Characterization of the subregional groundwater flow system at Yucca Mountain and vicinity, Nevada-California: Radioactive Waste Management and the Nuclear Fuel Cycle, v. 13, nos. 1-4, p. 51-61. 1989b, Preliminary simulations related to a large horizontal hydraulic gradient at the north end of Yucca Mountain, Nevada [abs.]: American Geophysical Union Transactions, EOS, v. 70, no. 15, p. 321. 1990, Geohydrology and evapotranspiration at Franklin Lake playa, Inyo County, California: U.S. Geological Survey Open-File Report 90-356, 96 p. 1991, Preliminary simulations showing potential effects of a wetter future climate coupled with a localized increase in hydraulic conductivity on the groundwater flow system of Yucca Mountain and vicinity, Nevada-California [abs.]: American Geophysical Union Transactions, EOS, v. 72, no. 17, p. 121.

Czarnecki, J.B., and Waddell, R.K., 1984, Finite-element simulation of ground-water flow in the vicinity of Yucca Mountain, Nevada-California: U.S. Geological Survey Water-Resources Investigations Report 84-4349, 38 p.

Czarnecki, J.B., and Wilson, W.E., 1991, Conceptual models of the regional ground-water flow and planned studies at Yucca Mountain, Nevada: Hydrological Science and Technology, v. 7, nos. 1-4, p. 15-25.

Czarnecki, J.B., Steinkampf, W.C., and Kroitoru, L., 1990, From where and by what flow paths does ground water beneath Yucca Mountain, Nevada originate? [abs.]: American Geophysical Union Transactions, EOS, v. 71, no. 43, p. 1299-1300.

D'Agnese, F.A., 1994, Using geoscientific information systems for three-dimensional modeling for regional ground-water flow system, Death Valley region, Nevada and California: Golden, Colorado School of Mines, $\mathrm{Ph} . \mathrm{D}$ dissertation, $331 \mathrm{p}$.

Daniels, J.J., Scott, J.H., and Hagstrum, J.T., 1981, Interpretation of geophysical well-log measurements in drill holes UE25a-4, $-5,-6$, and -7 , Yucca Mountain, Nevada Test Site: U.S. Geological Survey Open-File Report 81-389, 29 p.

Diehl, S.F., and Chornack, M.P, 1990, Stratigraphic correlation and petrography of the bedded tuffs, Yucca Mountain, Nye County, Nevada: U.S. Geological Survey Open-File Report 89-3, 152 p.

Downey, J.S., Kolm, K.E., and Gutentag, E.D., 1990, Selection of geohydrologic boundaries for ground-water flow models, Yucca Mountain, Nevada: Tucson,
University of Arizona, Proceedings of Waste Management '90, v. 2, p. 725-734.

Dudley, W.W., Jr., Barr, G.E., Chesnut, D.A., and Fridrich, C.J., eds., 1989, Review of a conceptual model and evidence for tectonic control of the groundwater system in the vicinity of Yucca Mountain, Nevada: Las Vegas, Nev., U.S. Department of Energy [Available from Yucca Mountain Project Office, P.O. Box 98608, Las Vegas, NV, 89109]

Dudley, W.W., Jr., and Larson, J.D., 1976, Effects of irrigation pumping on desert pupfish habitats in Ash Meadows, Nye County, Nevada: U.S. Geological Survey Professional Paper 927, 52 p.

Dressel, B.W., 1992, A hydro-seismic model of the Yucca Mountain waste repository site: Athens, Ohio University, Master's thesis, $111 \mathrm{p}$.

Eakin, T.E., Schoff, S.L., and Cohen, Philip, 1963, Regional hydrology of a part of southern Nevada-A reconnaissance: U.S. Geological Survey Trace-Element Investigations Report TEI 833, 40 p.

Erickson, J.R., and Waddell, R.K., 1985, Identification and characterization of hydrologic properties of fractured tuff using hydraulic and tracer tests-Test well USW H-4, Yucca Mountain, Nye County, Nevada: U.S. Geological Survey Water-Resources Investigations Report 85-4066, 30 p.

Ervin, E.M., Luckey, R.R., and Burkhardt, D.J., 1993, Summary of revised potentiometric-surface map for Yucca Mountain and vicinity, Nevada, in High Level Radioactive Waste Management, Proceedings of the Fourth Annual International Conference, Las Vegas, Nevada, April 26-30, 1993: La Grange Park, Ill., American Nuclear Society, p. 1554-1558.

1994, Revised potentiometric-surface map for Yucca Mountain and vicinity, Nevada: U.S. Geological Survey Water-Resources Investigations Report 93-4000, $17 \mathrm{p}$.

Faunt, C.C., 1994, Characterization of the three-dimensional hydrogeologic framework of the Death Valley region, Nevada and California: Golden, Colorado School of Mines, Ph.D. dissertation, 235 p.

Fenix \& Scisson, Inc., 1986a, NNWSI hole historiesUE-25 WT \#3, UE-25 WT \#4, UE-25 WT \#5, UE-25 WT \#6, UE-25 WT \#12, UE-25 WT \#13, UE-25 WT \#14, UE-25 WT \#15, UE-25 WT \#16, UE-25 WT \#17, UE-25 WT \#18, USW WT-1, USW WT-2, USW WT-7, USW WT-10, USW WT-11: U.S. Department of Energy Report DOE/NV/10322-10, 111 p.

1986b, NNWSI hole history-UE-25b \#1: U.S. Department of Energy Report DOE/NV/10322-13, $37 \mathrm{p}$. 
-1986c, NNWSI hole history-UE-25c \#1, UE-25c \#2, UE-25c \#3: U.S. Department of Energy Report DOE/ $\mathrm{NV} / 10322-14,61 \mathrm{p}$.

- 1986d, NNWSI hole history-UE-25p \#1: U.S. Department of Energy Report DOE/NV/10322-16, $39 \mathrm{p}$.

-1987a, NNWSI hole histories-USW H-1, USW H-3, USW H-4, USW H-5, USW H-6: U.S. Department of Energy Report DOE/NV/10322-18, 99 p.

-1987b, NNWSI hole histories-USW G-1, USW G-2, USW G-3, USW G-4, USW GA-1, USW GU-3: U.S. Department of Energy Report DOE/NV/10322-19, $187 \mathrm{p}$.

-1987c, NNWSI drilling and mining summary: U.S. Department of Energy Report DOE/NV/10322-24, $45 \mathrm{p}$.

Fenske, P.R., and Carnahan, C.L., 1976, Water table and related maps for Nevada Test Site and central Nevada test area: Reno, Nev., Desert Research Institute, 18 p.

Ferris, J.G., Knowles, D.B., Brown, R.H., and Stallman, R.W., 1962, Theory of aquifer tests: U.S. Geological Survey Water-Supply Paper 1536-E, 174 p.

Flanigan, V.J., 1981, A Slingram survey at Yucca Mountain on the Nevada Test Site: U.S. Geological Survey Open-File Report 81-980, 38 p.

Flint, A.L., and Flint, L.E., 1994, Spatial distribution of potential near surface moisture flux at Yucca Mountain in High Level Radioactive Waste Management, Proceedings of the Fifth Annual International Conference, Las Vegas, Nevada, May 22-26, 1994: La Grange Park, Ill., American Nuclear Society, p. 2352-2358.

Forester, R.M., and Smith, A.J., 1994, Late glacial climate estimates for southern Nevada; the Ostracode fossil record in High Level Radioactive Waste Management, Proceedings of the Fifth Annual International Conference, Las Vegas, Nevada, May 22-26, 1994: La Grange Park, Ill., American Nuclear Society, p. 2553-2561.

Fridrich, C.J., Dobson, D.C., and Dudley, W.W., Jr., 1991, A geologic hypothesis for the large gradient under Yucca Mountain, Nevada [abs.]: American Geophysical Union Transactions, EOS, v. 72, no. 17, p. 121.

Fridrich, C.J., Dudley, W.W., Jr., and Stuckless, J.S., 1994, Hydrogeologic analysis of the saturated-zone groundwater system under Yucca Mountain, Nevada: Journal of Hydrology, v. 154, nos. 1-4, p. 133-168.

Frizzell, V.A., Jr., and Shulters, Jacqueline, 1990, Geologic map of the Nevada Test Site, southern Nevada: U.S. Geological Survey Miscellaneous Investigations Series Map I-2046, scale 1:100,000.

Galloway, D.L., and Erickson, J.R., 1985, Tracer test for evaluating nonpumping intraborehole flow in fractured media: American Nuclear Society Transactions, v. 50, p. 192-193.
Galloway, D.L., and Rojstaczer, Stuart, 1988, Analysis of the frequency response of water levels in wells to earth tides and atmospheric loading, in Hitchon, Brian, and Bachu, Stefan, eds., Proceedings, Fourth annual Canadian/American conference on hydrology, fluid flow, heat transfer, and mass transport in fractured rocks, June 21-24, 1988, Banff, Alberta, Canada: Dublin, Ohio, National Water Well Association, p. 100-113.

Geldon, A.L., 1993, Preliminary hydrologic assessment of boreholes UE-25c \#1, UE-25c \#2, and UE-25c \#3, Yucca Mountain, Nye County, Nevada: U.S. Geological Survey Water-Resources Investigations Report 92-4016, 85 p.

1996, Results and interpretation of preliminary aquifer test in boreholes UE-25c \#1, UE-25c \#2, and UE-25c \#3, Yucca Mountain, Nye County, Nevada: U.S. Geological Survey Water-Resources Investigations Report 94-4177.

Gemmell, J.M., 1990, Water levels in periodically measured wells in the Yucca Mountain area, Nevada, 1988: U.S. Geological Survey Open-File Report 90-113, 47 p.

Glen, J.M., and Ponce, D.A., 1991, Aeromagnetic map of the Beatty quadrangle, Nevada-California: U.S. Geological Survey Open-File Report 91-105, 18 p.

Graybill, D.A., Rose, M.R., and Nials, F.L., 1994, Tree rings and climate-Implications for Great Basin paleoenvironmental studies in High Level Radioactive Waste Management, Proceedings of the Fifth Annual International Conference, Las Vegas, Nevada, May 22-26, 1994: La Grange Park, Ill., American Nuclear Society, p. 2569-2573.

Greenhaus, M.R., and Zablocki, C.J., 1982, Schlumberger resistivity survey of the Amargosa Desert, southern Nevada: U.S. Geological Survey Open-File Report 82-897, 150 p.

Harrison, D.H., 1971, New computer programs for the calculation of earth tides: Boulder, Colo., National Oceanic and Atmospheric Administration/University of Colorado, Cooperative Institute for Research in Environmental Sciences, 29 p.

Haws, S.J., 1990, The distribution of vertical groundwater flow in the saturated zone of the Yucca Mountain area-A cross-sectional finite element model: Las Vegas, University of Nevada, Masters thesis, $120 \mathrm{p}$.

Healey, D.L., Harris, R.N., Ponce, D.A., and Oliver, H.W., 1987, Complete Bouguer gravity map of the Nevada Test Site and vicinity, Nevada: U.S. Geological Survey Open-File Report 87-506, 20 p.

Healey, D.L., and Miller, C.H., 1971, Gravity survey of the Amargosa Desert area of Nevada and California: U.S. Geological Survey Report USGS-474-136, 32 p. 
Hoover, D.L., 1968, Genesis of zeolites, Nevada Test Site, in Eckel, E.B., ed., Nevada Test Site: Boulder, Colo., Geological Society of America, Memoir 110, p. 275-284.

Huber, N.K., 1988, Late Cenozoic evolution of the upper Amargosa River drainage system, southwestern Great Basin, Nevada and California: U.S. Geological Survey Open-File Report 87-617, 26 p.

Hunt, C.B., Robinson, T.W., Bowles, W.A., and Washburn, A.L., 1966, Hydrologic basin, Death Valley, California: U.S. Geological Survey Professional Paper 494-B, 138 p.

Jones, B.F., 1966, Geochemical evolution of closed basin water in the western Great Basin, in Rau, J.L., ed., Second symposium on salt: Cleveland, Ohio, Northern Ohio Geological Society, v. 1, p. 181-200.

Kane, M.F., and Bracken, R.E., 1983, Aeromagnetic map of Yucca Mountain and surrounding regions, southwest Nevada: U.S. Geological Survey Open-File Report 83-616, 19 p.

Kane, M.F., Webring, M.W., and Bhattacharyya, B.K., 1981 , A preliminary analysis of gravity and aeromagnetic surveys of the Timber Mountain area, southern Nevada: U.S. Geological Survey Open-File Report 81-189, $40 \mathrm{p}$.

Kerrisk, J.F., 1987, Groundwater chemistry at Yucca Mountain, Nevada, and vicinity: Los Alamos, N.M., Los Alamos National Laboratories Report LA-10929-MS, $118 \mathrm{p}$.

Kilroy, K.C., 1991, Ground-water conditions in Amargosa Desert, Nevada-California, 1952-87: U.S. Geological Survey Water-Resources Investigations Report 89-4101, 91 p.

Kolm, K.E., and Downey, J.S., 1994, Diverse flow pattern in the aquifers of the Amargosa Desert and vicinity, southern Nevada and California: Bulletin of the Association of Engineering Geologists, v. 31, no. 1, p. 33-47.

LaCamera, R.J., and Westenburg, C.L., 1994, Selected ground-water data for the Yucca Mountain region, southern Nevada and eastern California, through December 1992: U.S. Geological Survey Open-File Report 94-54, $161 \mathrm{p}$.

Lahoud, R.G., Lobmeyer, D.H., and Whitfield, M.S., Jr., 1984, Geohydrology of volcanic tuff penetrated by test well UE-25b \#1, Yucca Mountain, Nye County, Nevada: U.S. Geological Survey Water-Resources Investigations Report 84-4253, 44 p.

Langenheim, V.E., 1995, Magnetic and gravity studies of buried volcanic centers in the Amargosa Desert and Crater Flat, southwest Nevada: U.S. Geological Survey Open-File Report 95-564, 37 p.

Lehman, Linda, Rice, Jay, and Keen, Kerry, 1990, Cosine components in water levels, Yucca Mountain,
Nevada: Burnsville, Minn., L. Lehman and Associates, $15 \mathrm{p}$.

Levy, S.S., 1984a, Petrology of samples from drill holes USW H-3, H-4, and H-5, Yucca Mountain, Nevada: Los Alamos, N.M., Los Alamos National Laboratory Report LA-9706-MS, 77 p.

1984b, Studies of altered vitrophyre for the prediction of nuclear waste repository-induced thermal alteration at Yucca Mountain, Nevada, in McVay, G.L. ed., Proceedings of the Seventh International Symposium on the Scientific Basis for Nuclear Waste Management, Boston, Mass., Nov. 14-17, 1983: New York, Elsevier, v. 26, p. 959-966.

1991, Mineralogic alteration history and paleohydrology at Yucca Mountain, Nevada, in High Level Radioactive Waste Management, Proceedings of the Second Annual International Conference, Las Vegas, Nevada, April 28-May 3, 1991: La Grange Park, Ill., American Nuclear Society, p. 477-485.

Lipman, P.W., Christiansen, R.L., and O'Connor, J.T., 1966, A compositionally zoned ash-flow sheet in southern Nevada: U.S. Geological Survey Professional Paper 524-F, $47 \mathrm{p}$.

Lobmeyer, D.H., 1986, Geohydrology of rocks penetrated by test well USW G-4, Yucca Mountain, Nye County, Nevada: U.S. Geological Survey Water-Resources Investigations Report 86-4015, 38 p.

Lobmeyer, D.H., Luckey, R.R., O'Brien, G.M., and Burkhardt, D.J., 1995, Water levels in continuously monitored wells in the Yucca Mountain area, Nevada, 1989: U.S. Geological Survey Open-File Report 93-098, $173 \mathrm{p}$.

Lobmeyer, D.H., Whitfield, M.S., Jr., Lahoud, R.G., and Bruckheimer, Laura, 1983, Geohydrologic data for test well UE-25b \#1, Nevada Test Site, Nye County, Nevada: U.S. Geological Survey Open-File Report 83-855, $48 \mathrm{p}$.

Loeven, Colleen, 1993, A summary and discussion of hydrologic data from the Calico Hills nonwelded hydrogeologic unit at Yucca Mountain, Nevada: Los Alamos, N.M., Los Alamos National Laboratories Report LA-12376-MS, 102 p.

Luckey, R.R., Gutentag, E.D., Heimes, F.J., and Weeks, J.B., 1986, Digital simulation of ground-water flow in the High Plains aquifer in parts of Colorado, Kansas, Nebraska, New Mexico, Oklahoma, South Dakota, Texas, and Wyoming: U.S. Geological Survey Professional Paper 1400-D, 57 p.

Luckey, R.R., Lobmeyer, D.H., and Burkhardt, D.J., 1993, Water levels in continuously monitored wells in the Yucca Mountain area, Nevada, 1985-88: U.S. Geological Survey Open-File Report 91-493, 252 p. 
Ludwig, K.R., Peterman, Z.E., Simmons, K.R., and Gutentag, E.D., 1993, ${ }^{234} U^{234} U$ as a ground-water tracer, SW Nevada-SE California, in High Level Radioactive Waste Management, Proceedings of the Fourth Annual International Conference, Las Vegas, Nevada, April 26-30, 1993: La Grange Park, Ill., American Nuclear Society, p. 1567-1572.

Maldonado, Florian, 1985, Geologic map of the Jackass Flats area, Nye County, Nevada: U.S. Geological Survey Miscellaneous Series Investigations Map I-1519, scale 1:48,000.

Maldonado, Florian, and Koether, S.L., 1983, Stratigraphy, structure and some petrographic features of Tertiary volcanic rocks at the USW G-2 drill hole, Yucca Mountain, Nye County, Nevada: U.S. Geological Survey Open-File Report 83-732, 83 p.

Marshall, B.D., and Mahan, S.A., 1991, A model for the formation of pedogenic carbonate based on strontium isotope data from southwest Nevada [abs.]: Geological Society of America Abstracts with Programs, v. 23, no. 5, p. A118.

Marshall, B.D., Peterman, Z.E., and Stuckless, J.S., 1993, Strontium isotopic evidence for a higher water table at Yucca Mountain in High Level Radioactive Waste Management, Proceedings of the Fourth Annual International Conference, Las Vegas, Nevada, April 26-30, 1993: La Grange Park, Ill., American Nuclear Society, p. 1948-1952.

Matuska, N.A., 1989, The relationship of the Yucca Mountain repository block to the regional groundwater system-A geochemical model: Las Vegas, University of Nevada at Las Vegas, Master's thesis, $199 \mathrm{p}$.

McDonald, M.G., and Harbaugh, A.W., 1988, A modular three-dimensional finite-difference ground-water flow model: U.S. Geological Survey Techniques of WaterResources Investigations, book 6, chap. A1, 576 p.

McKinley, P.W., Long, M.P., and Benson, L.V., 1991, Chemical analyses of water from selected wells and springs in the Yucca Mountain area, Nevada and southeastern California: U.S. Geological Survey Open-File Report 90-355, $47 \mathrm{p}$.

Meinzer, O.E., 1923, Outline of ground-water hydrology, with definitions: U.S. Geological Survey WaterSupply Paper 494, $71 \mathrm{p}$.

Melchior, P., 1966, The Earth tides: Oxford [England], Pergamon Press Ltd., 458 p.

Mendenhall, W.C., 1909, Some desert watering places in southeastern California and southern Nevada: U.S. Geological Survey Water-Supply Paper 224, 98 p.

Mifflin, M.D., 1968, Delineation of ground-water flow systems in Nevada: Reno, University of Nevada, Desert Research Institute Publication 42004, 111 p. 1988, Region 5, Great Basin, in Back, William, Rosenshein, J.S., and Seaber, P.R., eds., Hydrogeo- logy: Boulder, Colo., Geological Society of America, The geology of North America, v. 0-2, p. 69-78.

Miller, G.A., 1977, Appraisal of the water resources of Death Valley, California-Nevada: U.S. Geological Survey Open-File Report 77-728, 68 p.

Moench, A.F., 1984, Double-porosity models for a fissured ground-water reservoir with a fracture skin: Water Resources Research, v. 20, no. 7, p. 831-846.

Montazer, P., and Wilson, W.E., 1984, Conceptual hydrologic model of flow in the unsaturated zone, Yucca Mountain, Nevada: U.S. Geological Survey WaterResources Investigations Report 84-4345, 55 p.

Moyer, T.C., and Geslin, J.K., 1995, Lithostratigraphy of the Calico Hills Formation and the Prow Pass Tuff (Crater Flat Group) at Yucca Mountain Nevada: U.S. Geological Survey Open-File Report 94-460, 59 p.

Muller, D.C., and Kibler, J.E., 1984, Preliminary analysis of geophysical logs from drill hole UE-25p \#1, Yucca Mountain, Nye County, Nevada: U.S. Geological Survey Open-File Report 84-649, 14 p.

1985, Preliminary analysis of geophysical logs from the WT series of drill holes, Yucca Mountain, Nye County, Nevada: U.S. Geological Survey Open-File Report 86-46, 30 p.

National Research Council, 1992, Ground water at Yucca Mountain-How high can it rise?, Report of the panel on coupled hydrologic/tectonic/hydrothermal systems at Yucca Mountain: Washington, D.C., National Academy Press, $231 \mathrm{p}$

Nelson, P.H., Muller, D.C., Schimschal, Ulrich, and Kibler, J.E., 1991, Geophysical logs and core measurements from forty boreholes at Yucca Mountain, Nevada: U.S. Geological Survey Geophysical Investigations Map GP-1001, 64 p.

Nimick, F.B., 1990, The thermal conductivity of seven ther$\mathrm{mal} / \mathrm{mechanical}$ units at Yucca Mountain, Nevada: Albuquerque, N.M., Sandia National Laboratories Report SAND88-1387, 70 p.

Noble, D.C., Weiss, S.J., and McKee, E.H., 1990, Style, timing, distribution, and direction of Neogene extension within and adjacent to the Goldfield section of the Walker Lane structural belt [abs.]: American Geophysical Union Transactions, EOS, v. 71, no. 17, p. 618-619.

Oatfield, W.J., and Czarnecki, J.B., 1991, Hydrogeologic inferences from drillers' logs and from gravity and resistivity surveys in the Amargosa Desert, southern Nevada: Journal of Hydrology, vol. 124, nos. 1-2, p. 131-158.

O'Brien, G.M., 1991, Water levels in periodically measured wells in the Yucca Mountain area, Nevada, 1989: U.S. Geological Survey Open-File Report 91-178, 51 p. 
1992, Earthquake-induced water-level fluctuations at Yucca Mountain, Nevada, April 1992: U.S. Geological Survey Open-File Report 92-137, 10 p.

-1993, Earthquake-induced water-level fluctuations at Yucca Mountain, Nevada, June 1992: U.S. Geological Survey Open-File Report 93-73, 12 p.

O'Brien, G.M., Tucci, Patrick, and Burkhardt, D.J., 1995, Water levels in the Yucca Mountain area, Nevada, 1992: U.S. Geological Survey Open-File Report 94-311, 74 p.

Oberlander, P.L., 1979, Development of a quasi threedimensional groundwater model for a portion of the Nevada Test Site: Reno, Nevada, Desert Research Institute, $72 \mathrm{p}$.

Oliver, H.W., Ponce, D.A., and Hunter, W.C., eds., 1995, Major results of geophysical investigations at Yucca Mountain and vicinity, southern Nevada: U.S. Geological Survey Open-File Report 95-74, 184 p.

Oliver, H.W., Ponce, D.A., and Sikora, R.F., 1991, Major results of gravity and magnetic studies at Yucca Mountain, Nevada, in High Level Radioactive Waste Management, Proceedings of the Second Annual International Conference, Las Vegas, Nevada, April 28-May 3, 1991: La Grange Park, Ill., American Nuclear Society, p. 787-794.

Ortiz, T.S., Williams, R.L., Nimick, F.B., Whittet, B.C., and South, D.L., 1985, A three-dimensional model of reference thermal/mechanical and hydrological stratigraphy at Yucca Mountain, southern Nevada: Albuquerque, N.M., Sandia National Laboratories Report SAND841076, $76 \mathrm{p}$.

Osterkamp, W.R., Lane, L.J., and Savard, C.S., 1994, Recharge estimates using a geomorphic/distributedparameter simulation approach, Amargosa River Basin: Water Resources Bulletin, v. 30, no. 3, p. 493-507.

Ostrowski, C.N., Nicholson, T.J., Evans, D.D., and Alexander, D.H., 1984, Disposal of high-level radioactive wastes in the unsaturated zone-Technical considerations: U.S. Nuclear Regulatory Commission Report NUREG-1046, 26 p.

Paces, J.B., Taylor, E.M., and Bush, Charles, 1993, Late Quaternary history and uranium isotopic composition of ground water discharge deposits, Crater Flat, Nevada, in High Level Radioactive Waste Management, Proceedings of the Fourth Annual International Conference, Las Vegas, Nevada, April 26-30, 1993: La Grange Park, Ill., American Nuclear Society, p. 1573-1580.

Pankratz, L.W., 1982, Reconnaissance seismic refraction studies at Calico Hills, Wahmonie, and Yucca Mountain, southwest Nevada Test Site, Nye County, Nevada: U.S. Geological Survey Open-File Report 82-478, $25 \mathrm{p}$.
Perfect, D.L., Faunt, C.C., Steinkampf, W.C., and Turner, A.K., 1995, Hydrochemical data base for the Death Valley region, California and Nevada: U.S. Geological Survey Open-File Report 94-305, 10 p.

Peterman, Z.E., and Stuckless, J.S., 1993, Isotopic evidence of complex ground-water flow at Yucca Mountain, Nevada, USA, in High Level Radioactive Waste Management, Proceedings of the Fourth Annual International Conference, Las Vegas, Nevada, April 26-30, 1993: La Grange Park, Ill., American Nuclear Society, p. $1559-1566$.

Peterman, Z.E., Stuckless, J.S., Marshall, B.D., Mahan, S.A., and Futa, K., 1992, Strontium isotope geochemistry of calcite fracture fillings in deep core, Yucca Mountain, Nevada-A progress report in High Level Radioactive Waste Management, Proceedings of the Third Annual International Conference, Las Vegas, Nevada, April 12-16, 1992: La Grange Park, Ill., American Nuclear Society, p. 1582-1586.

Pistrang, M.A., and Kunkel, Fred, 1964, A brief geologic and hydrologic reconnaissance of the Furnace Creek Wash area, Death Valley National Monument, California: U.S. Geological Survey Water Supply Paper 1779-Y, 35 p.

Ponce, D.A., Harris, R.N., and Oliver, H.W., 1988, Isostatic gravity map of the Nevada Test Site and vicinity, Nevada: U.S. Geological Survey Open-File Report 88-664, 21 p.

Ponce, D.A., and Langenheim, V.E., 1995, Gravity and magnetic investigations of the Ghost Dance and Solitario Canyon Faults, Yucca Mountain, Nevada: U.S. Geological Survey Open-File Report 95-521, 26 p.

Ponce, D.A., Sikora, R.F., Roberts, C.W., Marin, R.L., and Halvorson, P.E., 1995, Magnetic investigations along selected high-resolution seismic traverses in the central block of Yucca Mountain, Nevada: U.S. Geological Survey Open-File Report 95-667, 23 p.

Quade, Jay, and Cerling, T.E., 1990, Stable isotope evidence for pedogenic origin of fracture filling carbonates in Trench 14 near Yucca Mountain, Nevada: Science, v. 250 , no. 4987 , p. $1549-1552$.

Rice, W.A., 1984, Preliminary two-dimensional regional hydrologic model of the Nevada Test Site and vicinity: Albuquerque, N.M., Sandia National Laboratories Report SAND83-7466, 89 p.

Robinson, G.D., 1985, Structure of pre-Cenozoic rocks in the vicinity of Yucca Mountain, Nye County, Nevada-A potential nuclear-waste disposal site: U.S. Geological Survey Bulletin 1647, 22 p.

Robison, J.H., 1984, Ground-water level data and preliminary potentiometric-surface maps, Yucca Mountain and vicinity, Nye County, Nevada: U.S. Geological Survey Water-Resources Investigations Report 84-4197, 8 p. 
-1986, Letter from J.H. Robison (U.S. Geological Survey, Lakewood, Colorado) to D.L. Vieth (U.S. Department of Energy/Nevada Operations Office, Las Vegas, Nevada), September 17, 1986; regarding revisions of Yucca Mountain water levels reported in Robison, 1984.

Robison, J.H., and Craig, R.W., 1991, Geohydrology of rocks penetrated by test well USW H-5, Yucca Mountain, Nye County, Nevada: U.S. Geological Survey Water-Resources Investigations Report 88-4168, 44 p.

Robison, J.H., Stephens, D.M., Luckey, R.R., and Baldwin, D.A., 1988, Water levels in periodically measured wells in the Yucca Mountain area, Nevada, 1981-1987: U.S. Geological Survey Open-File Report 88-468, 132 p.

Roseboom, E.H., Jr., 1983, Disposal of high-level nuclear waste above the water table in arid regions: U.S. Geological Survey Circular 903, $21 \mathrm{p}$.

Ross, Benjamin, 1984, A conceptual model of deep unsaturated zone with neglible recharge: Water Resources Research, v. 20, no. 11, p. 1627-1629.

Ross, C.S., and Smith, R.L., 1961, Ash-flow tuffs-Their origin, geologic relations and identification: U.S. Geological Survey Professional Paper 366, 81 p.

Rush, F.E., 1968, Index of hydrographic areas in Nevada: Carson City, Nevada Department of Conservation and Water Resources, Division of Water Resources, Water Resources Information Series Report 6, 38 p.

1971 [1970 on cover], Regional ground-water systems in the Nevada Test Site area, Nye, Lincoln, and Clark Counties, Nevada: Carson City, Nevada Department of Conservation and Water Resources, Division of Water Resources, Water Resources Reconnaissance Series Report 54, 25 p.

Rush, F.E., Thordarson, William, and Bruckheimer, Laura, 1983, Geohydrologic and drill-hole data for test well USW H-1, adjacent to Nevada Test Site, Nye County, Nevada: U.S. Geological Survey Open-File Report 83-141, 38 p.

Rush, F.E., Thordarson, William, and Pyles, D.G., 1984, Geohydrology of test well USW H-1, Yucca Mountain, Nye County, Nevada: U.S. Geological Survey WaterResources Investigations Report 84-4032, 56 p.

Sass, J.H., and Lachenbruch, A.H., 1980, Analysis of thermal data from drill holes UE25a-3 and UE25a-1, Calico Hills and Yucca Mountain, Nevada Test Site: U.S. Geological Survey Open-File Report 80-826, $25 \mathrm{p}$.

1982, Preliminary interpretation of thermal data from the Nevada Test Site: U.S. Geological Survey OpenFile Report 82-973, 30 p.

Sass, J.H., Lachenbruch, A.H., Dudley, W.W., Jr., Priest, S.S., and Munroe, R.J., 1988, Temperature, thermal conductivity, and heat flow near Yucca Moun- tain, Nevada-Some tectonic and hydrologic implications: U.S. Geological Survey Open-File Report 87-649, $118 \mathrm{p}$.

Savard, C.S., 1994, Ground-water recharge in Fortymile Wash near Yucca Mountain, Nevada, 1992-93, in High Level Radioactive Waste Management, Proceedings of the Fifth Annual International Conference, Las Vegas, Nevada, May 22-26, 1994: La Grange Park, Ill., American Nuclear Society, p. 1805-1813.

Savard, C.S., Flint, L.E., Ambos, D.S., and Kane, T.G., 1992, Runoff, infiltration, and recharge near Yucca Mountain, Nevada, 1992 [abs.]: American Geophysical Union Transactions, EOS, v. 73, no. 43, p. 202.

Sawyer, D.A., Fleck, R.J., Lanphere, M.A., Warren, R.G., and Broxton, D.E., 1990, Episodic volcanism in the southwest Nevada volcanic field-New ${ }^{40} \mathrm{Ar} /{ }^{39} \mathrm{Ar}$ geochronologic results [abs.]: American Geophysical Union Transactions, EOS, v. 71, no. 43, p. 1296.

Sawyer, D.A., Fleck, R.J., Lanphere, M.A., Warren, R.G., Broxton, D.E., and Hudson, M.R., 1994, Episodic caldera volcanism in the Miocene southwestern Nevada volcanic field-Revised stratigraphic framework, ${ }^{40} \mathrm{Ar} /{ }^{\beta 9} \mathrm{Ar}$ geochronology, and implications for magmatism and extension: Geological Society of America Bulletin, v. 106, no. 10, p. 1304-1318.

Scott, R.B., Bath, G.D., Flanigan, V.J., Hoover, D.B., Rosenbaum, J.G., and Spengler, R.W., 1984, Geological and geophysical evidence of structures in northwest-trending washes, Yucca Mountain, southern Nevada, and their possible significance to a nuclear waste repository in the unsaturated zone: U.S. Geological Survey Open-File Report 84-567, 23 p.

Scott, R.B., and Bonk, Jerry, 1984, Preliminary geologic map of Yucca Mountain, Nye County, Nevada, with geologic sections: U.S. Geological Survey Open-File Report 84-494, scale 1:12,000, 3 sheets.

Scott, R.B., and Castellanos, Mayra, 1984, Stratigraphic and structural relations of volcanic rocks in drill holes USW GU-3 and USW G-3, Yucca Mountain, Nye County, Nevada: U.S. Geological Survey Open-File Report 84-491, 121 p.

Scott, R.B., Spengler, R.W., Diehl, S.F., Lappin, A.R., and Chornack, M.P., 1983, Geologic character of tuffs in the unsaturated zone at Yucca Mountain, southern Nevada, in Mercer, J.W., Rao, P.S.C., and Marine, I.W., eds., Role of the unsaturated zone in radioactive and hazardous waste disposal: Ann Arbor, Mich., Ann Arbor Sciences Publishers, p. 289-335.

Senterfit, R.M., Hoover, D.B., and Chornack, M.P., 1982, Resistivity sounding investigation by the Schlumberger method in the Yucca Mountain and Jackass Flats area, Nevada Test Site, Nevada: U.S. Geological Survey Open-File Report 82-1043, 38 p. 
Sibson, R.H., Moore, J.McM., and Rankin, A.H., 1975, Seismic pumping-A hydrothermal fluid transport mechanism: Geological Society of London Journal, v. 131, part 6, p. 653-659.

Simonds, F.W., and Scott, R.B., 1987, Detachment faulting and hydrothermal alteration in the Calico Hills, SW Nevada [abs.]: American Geophysical Union Transactions, EOS, v. 68, no. 44, p. 1475.

Sinton, P.O., 1987, Three-dimensional, steady-state, finite-difference model of the ground-water flow system in the Death Valley ground-water basin, NevadaCalifornia: Golden, Colorado School of Mines, Master's thesis, $145 \mathrm{p}$.

Sinton, P.O., 1989, Characterization of the large hydraulic gradient beneath the north end of Yucca Mountain, Nevada [abs.]: American Geophysical Union Transactions, EOS, v. 70 , no. 15 , p. 321.

Smyth, J.R., and Caporuscio, F.A., 1981, Review of the thermal stability and cation exchange properties of the zeolite minerals clinoptilolite, mordenite, and analcime-Applications to radioactive waste isolation in silicic tuffs: Los Alamos, N.M., Los Alamos National Laboratory Report LA-8841-MS, 30 p.

Snyder, D.B., and Carr, W.J., 1982, Preliminary results of gravity investigations at Yucca Mountain and vicinity, southern Nye County, Nevada: U.S. Geological Survey Open-File Report 82-701, 36 p.

1984, Interpretation of gravity data in a complex volcano-tectonic setting, southwestern Nevada: Journal of Geophysical Research, v. 89, no. B12, p. 10193-10206.

Spaulding, W.G., 1985, Vegetation and climates of the last 45,000 years in the vicinity of the Nevada Test Site, south-central Nevada: U.S. Geological Survey Professional Paper 1329, $83 \mathrm{p}$.

Spengler, R.W., Braun, C.A., Linden, R.M., Martin, L.G., Ross-Brown, D.M., and Blackburn, R.L., 1993, Structural character of the Ghost Dance Fault, Yucca Mountain, Nevada, in High Level Radioactive Waste Management, Proceedings of the Fourth Annual International Conference, Las Vegas, Nevada, April 26-30, 1993: La Grange Park, Ill., American Nuclear Society, p. 653-659.

Spengler, R.W., Braun, C.A., Martin, L.G., and Weisenberg, C.W., 1994, The Sundance Fault-A newly recognized shear zone at Yucca Mountain, Nevada, in High Level Radioactive Waste Management, Proceedings of the Fifth Annual International Conference, Las Vegas, Nevada, May 22-26, 1994: La Grange Park, Ill., American Nuclear Society, p. 2359-2366.

Spengler, R.W., Byers, F.M., Jr., and Warner, J.B., 1981, Stratigraphy and structure of volcanic rocks in drill hole USW G-1, Yucca Mountain, Nye County,
Nevada: U.S. Geological Survey Open-File Report 81-1349, 50 p.

Spengler, R.W., Chornack, M.P., Muller, D.C., and Kibler, J.E., 1984, Stratigraphic and structural characteristics of volcanic rocks in core hole USW G-4, Yucca Mountain, Nye County, Nevada: U.S. Geological Survey Open-File Report 84-789, 77 p.

Spengler, R.W., Muller, D.C., and Livermore, R.B., 1979, Preliminary report on the geology and geophysics of drill hole UE 25a-1, Yucca Mountain, Nevada Test Site: U.S. Geological Survey Open-File Report 79-1244, 43 p.

Spengler, R.W., and Peterman, Z.E., 1991, Distribution of rubidium, strontium, and zerconium in tuff from two deep coreholes at Yucca Mountain, Nevada, in High Level Radioactive Waste Management, Proceedings of the Second Annual International Conference, Las Vegas, Nevada, April 28-May 3, 1991: La Grange Park, Ill., American Nuclear Society, p. 1416-1422.

Spengler, R.W., and Rosenbaum, J.G., 1980, Preliminary interpretations of geologic results obtained from boreholes UE25a-4, -5, -6, and -7, Yucca Mountain, Nevada Test Site: U.S. Geological Survey Open-File Report 80-929, 33 p.

Squires, R.R., and Young, R.L., 1984, Flood potential of Fortymile Wash and its principal southeastern tributaries, Nevada Test Site, southern Nevada: U.S. Geological Survey Water-Resources Investigations Report 83-4001, 33 p.

Stock, J.M., and Healey, J.H., 1988, Stress field at Yucca Mountain, in Carr, M.D., and Yount, J.C., eds., Geologic and hydrologic investigations of a potential nuclear waste disposal site at Yucca Mountain, southern Nevada: U.S. Geological Survey Bulletin 1790, p. 87-93.

Stock, J.M., Healy, J.H., and Hickman, S.H., 1984, Report on televiewer log and stress measurements in core hole USW G-2, Nevada Test Site, October-November 1982: U.S. Geological Survey Open-File Report 84-172, 31 p.

Stuckless, J.S., Peterman, Z.E., and Muhs, D.R., 1991, $\mathrm{U}$ and $\mathrm{Sr}$ isotopes in ground water and calcite, Yucca Mountain, Nevada-Evidence against upwelling water: Science, v. 254, no. 5031, p. 551-554.

Stuckless, J.S., Whelan, J.F., and Steinkampf, W.C., 1991, Isotopic discontinuities in ground water beneath Yucca Mountain, Nevada, in High Level Radioactive Waste Management, Proceedings of the Second Annual International Conference, Las Vegas, Nevada, April 28May 3, 1991: La Grange Park, Ill., American Nuclear Society, p. 1410-1415. 
Swadley, W.C., and Carr, W.J., 1987, Geologic map of the Quaternary and Tertiary deposits of the Big Dune quadrangle, Nye County, Nevada, and Inyo County, California: U.S. Geological Survey Miscellaneous Investigations Series Map I-1767, 20 p., scale 1:48,000.

Swadley, W.C., and Hoover, D.L., 1989, Geologic map of the surficial deposits of the Topopah Spring quadrangle, Nye County, Nevada: U.S. Geological Survey Miscellaneous Investigations Series Map I-2018, 16 p., scale 1:24,000.

Swadley, W.C., and Parrish, L.D., 1988, Surficial geologic map of the Bare Mountain quadrangle, Nye County, Nevada: U.S. Geological Survey Miscellaneous Investigations Series Map I-1826, 13 p., scale 1:48,000.

Szymanski, J.S., 1989, Conceptual considerations of the Yucca Mountain groundwater system with special emphasis on the adequacy of this system to accommodate a high-level nuclear waste repository: Las Vegas, Nev., U.S. Department of Energy, 3 v. [Available from Yucca Mountain Project Office, P.O. Box 98608, Las Vegas, NV, 89109.]

Thomas, J.M., Lyles, B.F., and Carpenter, L.A., 1991, Chemical and isotopic data for water from wells, springs, and streams in carbonate-rock terrain of southern and eastern Nevada and southeastern California, 1985-88: U.S. Geological Survey Open-File Report 89-422, $24 \mathrm{p}$.

Thordarson, William, 1983, Geohydrologic data and test results from well J-13, Nevada Test Site, Nye County, Nevada: U.S. Geological Survey Water-Resources Investigations Report 83-4171, $57 \mathrm{p}$.

Thordarson, William, and Howells, Lewis, 1987, Hydraulic tests and chemical quality of water at well USW VH-1, Crater Flat, Nye County, Nevada: U.S. Geological Survey Water-Resources Investigations Report 86-4359, 20 p.

Thordarson, William, Rush, F.E., Spengler, R.W., and Waddell, S.J., 1984, Geohydrologic and drill-hole data for test well USW H-3, Yucca Mountain, Nye County, Nevada: U.S. Geological Survey Open-File Report 84-149, 28 p.

Thordarson, William, Rush, F.E., and Waddell, S.J., 1985, Geohydrology of test well USW H-3, Yucca Mountain, Nye County, Nevada: U.S. Geological Survey WaterResources Investigations Report 84-4272, 38 p.

Tucci, Patrick, and Burkhardt, D.J., 1995, Potentiometricsurface map, 1993, Yucca Mountain and vicinity, Nevada: U.S. Geological Survey Water-Resources Investigations Report 95-4149, 15 p.

Tucci, Patrick, O'Brien, G.M., and Burkhardt, D.J., in press, Water levels in the Yucca Mountain area, 1990-1991: U.S. Geological Survey Open-File Report 94-111.
U.S. Department of Energy, 1986, Environmental assessment, Yucca Mountain site, Nevada Research and Development Area, Nevada: U.S. Department of Energy Report DOE/RW-0073, 3 vol., variously paged.

-1988, Site characterization plan, Yucca Mountain site, Nevada Research and Development Area, Nevada: U.S. Department of Energy Report DOE/RW-0199, 8 vol., variously paged.

$1990 \mathrm{a}$, Characterization of the site saturated-zone ground-water flow system: U.S. Department of Energy Study Plan YMP-USGS-SP 8.3.1.2.3.1, R0, 1 vol., variously paged.

1990b, Characterization of the Yucca Mountain regional ground-water flow system: U.S. Department of Energy Study Plan YMP-USGS-SP 8.3.1.2.1.3, R0, 1 vol., variously paged.

1991, Regional hydrologic system synthesis and modeling: U.S. Department of Energy Study Plan YMPUSGS-SP 8.3.1.2.1.4, R0, 1 vol., variously paged. 1992a, Characterization of the Yucca Mountain saturated-zone hydrochemistry: U.S. Department of Energy Study Plan YMP-USGS-SP 8.3.1.2.3.2, R0, 1 vol., variously paged.

1992b, Site saturated-zone hydrologic system synthesis and modeling: U.S. Department of Energy Study Plan YMP-USGS-SP 8.3.1.2.3.3, R0, 1 vol., variously paged.

1992c, Characterization of the Yucca Mountain Quaternary regional hydrology: U.S. Department of Energy Study Plan YMP-USGS-SP 8.3.1.5.2.1, R2, 1 vol., variously paged.

U.S. Geological Survey, 1984, A summary of geologic studies through January 1, 1983, of a potential high-level radioactive waste disposal site at Yucca Mountain, southern Nye County, Nevada: U.S. Geological Survey Open-File Report 84-792, 103 p.

U.S. Nuclear Regulatory Commission, 1986, Disposal of high-level radioactive waste in geologic repositories: Code of Federal Regulations, title 10, part 60, p. 597-628.

Von Konynenburg, R.A., Smith, C.F., Culham, H.W., and Otto, C.A., Jr., 1985, Behavior of carbon-14 in waste packages for spent fuel in a repository in tuff, in Jantzen, C.M., Stone, J.A., and Ewing, R.C., Proceedings of the Eighth International Symposium on the Scientific Basis for Nuclear Waste Management, Boston, Mass., Nov. 26-29, 1984: Pittsburgh, Penn., Materials Research Society, p. 405-412.

Waddell, R.K., 1982, Two-dimensional, steady-state model of ground-water flow, Nevada Test Site and vicinity, Nevada-California: U.S. Geological Survey WaterResources Investigations Report 82-4085, 72 p. 
Waddell, R.K., 1984, Hydrologic and drill-hole data for test wells UE-29a \#1 and UE-29a \#2, Fortymile Canyon, Nevada Test Site: U.S. Geological Survey Open-File Report 84-142, 25 p.

Waddell, R.K., Robison, J.H., and Blankennagel, R.K., 1984, Hydrology of Yucca Mountain and vicinity, Nevada-California-Investigative results through mid-1983: U.S. Geological Survey Water-Resources Investigations Report 84-4267, 72 p.

Walker, G.E., and Eakin, T.E., 1963, Geology and ground water of Amargosa Desert, Nevada-California: Carson City, Nevada, Department of Conservation and Natural Resources, Ground-Water Resources-Reconnaissance Series Report 14, 45 p.

Whelan, J.F., and Stuckless, J.S., 1992, Paleohydrologic implications of the stable isotopic composition of secondary calcite within the Tertiary volcanic rocks of Yucca Mountain, Nevada, in High Level Radioactive Waste Management, Proceedings of the Third Annual International Conference, Las Vegas, Nevada, April 12-16, 1992: La Grange Park, Ill., American Nuclear Society, p. 1572-1581.

Whitfield, M.S., Jr., Eshom, E.P., Thordarson, William, and Schaefer, D.H., 1985, Geohydrology of rocks penetrated by test well USW H-4, Yucca Mountain, Nye County, Nevada: U.S. Geological Survey WaterResources Investigations Report 85-4030, 33 p.

Whitfield, M.S., Jr., Thordarson, William, and Eshom, E.P., 1984, Geohydrologic and drill-hole data for test well USW H-4, Yucca Mountain, Nye County, Nevada: U.S. Geological Survey Open-File Report 84-449, $39 \mathrm{p}$.

Wilson, M.L., Gauthier, J.H., Barnard, R.W., Barr, G.E., Dockery, H.A., Dunn, Ellen, Eaton, R.R., Guerin, D.C., Lu, Ning, Martinez, M.J., Nilson, Robert, Rautman, C.A., Robey, T.H., Ross, Benjamin, Ryder, E.E., Schenker, A.R., Shannon, S.A., Skinner, L.H., Halsey, W.G., Gansemer, James, Lewis, L.C., Lamont, A.D., Triay, I.R., Meijer, Arend, and Morris, D.E., 1994, Total-system performance assessment for Yucca Mountain-SNL second iteration (TSPA-1993):
Albuquerque, N.M., Sandia National Laboratories Report SAND93-2675, 3 vols.

Winograd, I.J., 1962, Interbasin movement of ground water at the Nevada Test Site, Nevada, in Short papers in geology and hydrology: U.S. Geological Survey Professional Paper 450-C, p. 108-111.

-1971, Origin of major springs in the Amargosa Desert of Nevada and Death Valley, California: Tucson, University of Arizona, Ph.D. dissertation, 170 p.

-1981, Radioactive waste disposal in thick unsaturated zones: Science, v. 212, no. 4502, p. 1457-1464.

1991, Yucca Mountain as a nuclear-waste repository-Neither myth nor millennium: U.S. Geological Survey Open-File Report 91-170, 25 p.

Winograd, I.J., and Doty, G.C., 1980, Paleohydrology of the southern Great Basin, with special reference to water table fluctuations beneath the Nevada Test Site during the late Pleistocene: U.S. Geological Survey OpenFile Report 80-569, 91 p.

Winograd, I.J., and Pearson, F.J., Jr., 1976, Major carbon 14 anomaly in a regional carbonate aquifer-Possible evidence for mega scale channeling, south-central Great Basin: Water Resources Research, v. 12, no. 6, p. 1125-1143.

Winograd, I.J., and Szabo, B.J., 1986, Water-table decline in the south-central Great Basin during the Quaternary period-Implications for toxic-waste disposal: U.S. Geological Survey Open-File Report 85-697, 18 p.

Winograd, I.J., and Thordarson, William, 1968, Structural control of ground-water movement in the miogeosynclinal rocks of south-central Nevada, in Eckel, E.B., ed., Nevada Test Site: Boulder, Colo., Geological Society of America, Memoir 110, p. 35-48.

-1975, Hydrogeologic and hydrochemical framework, south-central Great Basin, Nevada-California, with special reference to the Nevada Test Site: U.S. Geological Survey Professional Paper 712-C, $126 \mathrm{p}$.

Young, R.A., 1972, Water supply for the Nuclear Rocket Development Station at the U.S. Atomic Energy Commission's Nevada Test Site: U.S. Geological Survey Water-Supply Paper 1938, 19 p. 